UNIVERSIDADE DE SÃO PAULO

FACULDADE DE ECONOMIA, ADMINISTRAÇÃO E CONTABILIDADE DEPARTAMENTO DE ADMINISTRAÇÃO PROGRAMA DE PÓS-GRADUAÇÃO EM ADMINISTRAÇÃo

O PROCESSO DE DESENVOLVIMENTO DO PLANEJAMENTO ESTRATÉGICO EM MODELOS ORGANIZACIONAIS DE EMPRESAS TIPO EMPREENDEDORA, MÁQUINA, PROFISSIONAL E INOVADORA: UM ESTUDO DE CASOS MÚLTIPLOS

Silvio Luiz Tadeu Bertoncello

Orientador: Prof. Dr. Antonio Cesar Amaru Maximiano

SÃO PAULO

2009 
Prof. Dr. João Grandino Rodas

Reitor da Universidade de São Paulo

Prof. Dr. Carlos Roberto Azzoni

Diretor da Faculdade de Economia, Administração e Contabilidade

Prof. Dr. Adalberto Américo Fischmann

Chefe do Departamento de Administração

Prof. Dr. Lindolfo Galvão de Albuquerque

Coordenador do Programa de Pós-Graduação em Administração 


\section{O PROCESSO DE DESENVOLVIMENTO DO PLANEJAMENTO ESTRATÉGICO EM MODELOS ORGANIZACIONAIS DE EMPRESAS TIPO EMPREENDEDORA, MÁQUINA, PROFISSIONAL E INOVADORA: UM ESTUDO DE CASOS \\ MÚLTIPLOS}

Tese apresentada ao Programa de PósGraduação em Administração da Faculdade de Economia, Administração e Contabilidade da Universidade de São Paulo como requisito para a obtenção do título de Doutor em Administração.

Orientador: Prof. Dr. Antonio Cesar Amaru Maximiano 
Tese defendida e aprovada na Faculdade de Economia, Administração e Contabilidade da Universidade de São Paulo - Programa de PósGraduação em Administração, pela seguinte banca examinadora:

Prof. Dr. Antonio Cesar Amaru Maximiano

Prof. Dr. Martinho Isnard Ribeiro de Almeida

Prof. Dr. Hamilton Luiz Correa

Prof. Dr. Antonio Vico Mañas

Prof. Dr. Tharcisio Bierrenbach de Souza Santos

\section{FICHA CATALOGRÁFICA}

Elaborada pela Seção de Processamento Técnico do SBD/FEA/USP

Bertoncello, Silvio Luiz Tadeu

O processo de desenvolvimento do planejamento estratégico em modelos organizacionais de empresas tipo empreendedora, máquina, profissional e inovadora : um estudo de casos múltiplos / Silvio Luiz Tadeu Bertoncello. -- São Paulo, 2009.

$140 \mathrm{p}$.

Tese (Doutorado) - Universidade de São Paulo, 2010.

Bibliografia.

1. Planejamento estratégico 2. Organização (Administração) - Modelos 3. Estrutura organizacional I. Universidade de São Paulo. Faculdade de Economia, Administração e Contabilidade II. Título.

$$
\text { CDD }-658.401
$$


À minha esposa Regina e meus filhos Thiago e Isabella,

Por toda a compreensão pela minha ausência, por todo o incentivo nas horas mais difíceis, preenchendo de amor todos os dias de luta. 
Agradeço ao Prof. Dr. Antonio Cesar Amaru Maximiano, pela orientação e pelo estímulo para conclusão do trabalho.

Ao Prof. Dr. Antonio Vico Mañas e Prof. Dr. Martinho R. Isnard Almeida, pelo apoio, estímulo e preciosas sugestões na qualificação.

Aos entrevistados:

- José Roberto Maciel

- Everton Granero

- Reinaldo Kuhl

- Luiz Affonso

- Fernand Alphen

- Antonio Carlos Cipriano

- Henrique Vailati Neto

- Tharcisio Bierrenbach de Souza Santos

- Antonio Carlos Garcia

Pela colaboração, e enriquecimento deste trabalho. 


\section{RESUMO}

Este trabalho tem como objetivo explicar os processos de desenvolvimento do planejamento estratégico em diferentes modelos organizacionais, identificando suas relações e propondo uma estrutura diferente ou ajustada. O processo de desenvolvimento do planejamento estratégico está relacionado a um composto de ações, passos, análises e decisões que visam o alcance de objetivos previamente estabelecidos. Os modelos organizacionais são interpretados a partir de fatores e características que tipificam uma organização. Os modelos analisados foram: organizações tipo empreendedora, centrada no empreendedor que a fundou; máquina, com processos padronizados funcionando como máquinas integradas; profissional, dependem da habilidade dos profissionais que nelas trabalham; e inovadora baseada em projetos e grupos de especialistas.

Palavras-chave: Planejamento estratégico. Modelos organizacionais. Estruturas organizacionais. 


\begin{abstract}
This paper aims to explain the process of strategic planning development at different organizational models, identifying its relationships and proposing a different or adjusted frame. The process of the strategic planning developing is related to a composite of actions, steps, analysis and decisions that aim the achieving of previously established objectives. The organizational models are interpreted from aspects and characteristics that typifying an organization. The models analyzed were: family-owned business; machine: standardized processes running as integrated machines; professional: depend on skilled professionals; and innovative: based on projects and expert groups.
\end{abstract}

Key words: Strategic planning. Organizational models. Organizational structures. 


\section{SUMÁRIO}

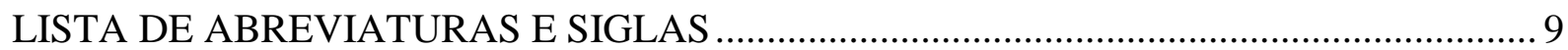

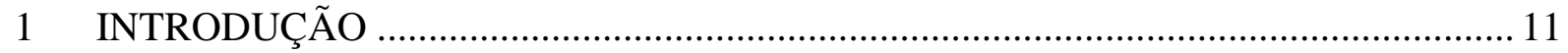

1.1 Contextualização e caracterização do tema ........................................................ 11

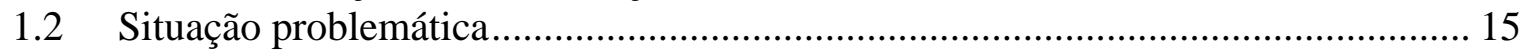

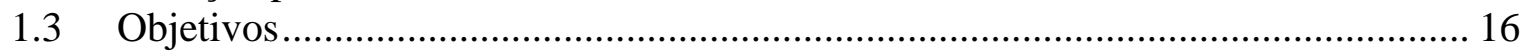

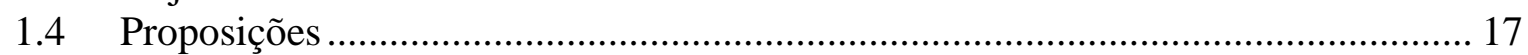

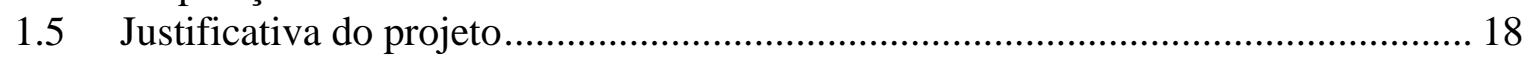

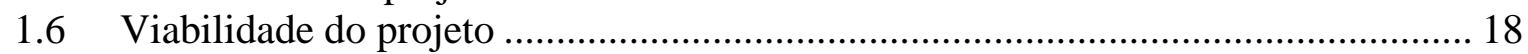

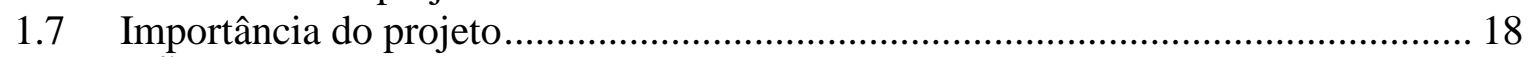

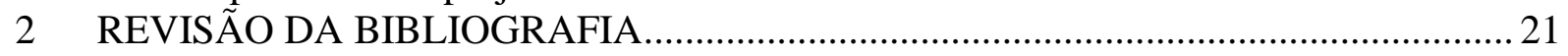

2.1 O conceito de estratégia e sua evolução .............................................................. 21

2.2 Análise estrutural da indústria, base para a visão de fora para dentro..................... 23

2.2.1 A importância das estratégias de escala e escopo no desenvolvimento da visão de fora para dentro .................................................................... 26

2.3 A perspectiva da visão baseada em recursos, o conceito de dentro para fora ......... 27

2.3.1 Cultura e competências da visão baseada em recursos .................................. 32

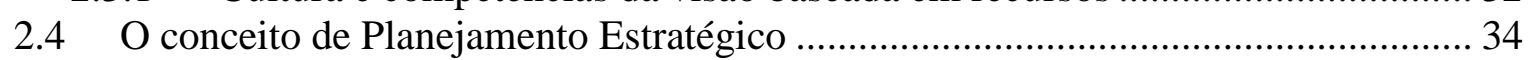

2.5 Linhas de pensamento das escolas do planejamento estratégico.............................. 36

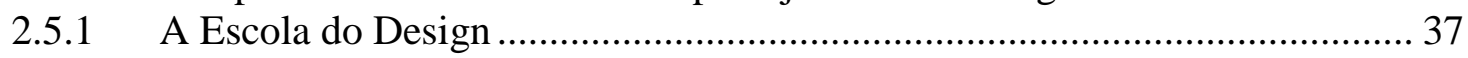

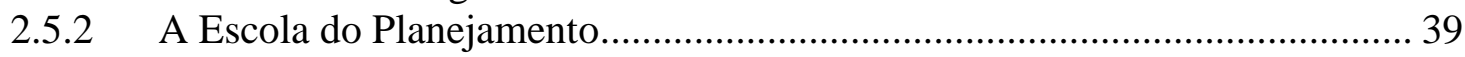

2.5.3 A escola do Posicionamento ........................................................................ 41

2.6 Planejamento estratégico para Fischmann e Almeida (1991), Almeida (1997 e 2003) e Rebouças (2003) .............................................................................. 42

2.7 Planejamento estratégico para Wright et al (2000), Thompson e Strickland (2000), Aaker (2001) e Kluyver e Pearce (2007) .................................................... 46

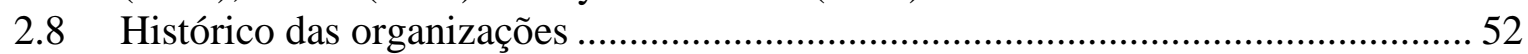

2.8.1 As relações dos grupos sociais como organizações .................................... 52

2.8.2 Organizações formais e a burocracia ...................................................... 53

2.9 Linhas de pensamento nos estudos das organizações........................................... 54

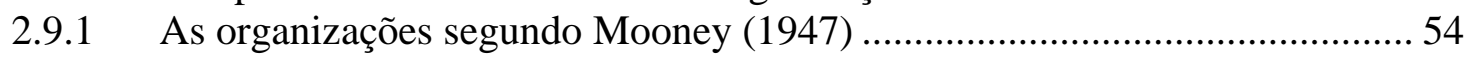

2.9.2 Modelos alternativos de organização de Burns e Stalker (1961) ................... 57

2.9.3 Tipologias de poder nas organizações segundo Etzioni (1974 e 1976) .......... 58

2.9.4 Novos modelos das organizações segundo Mintzberg (1979 e 2006) ............ 60

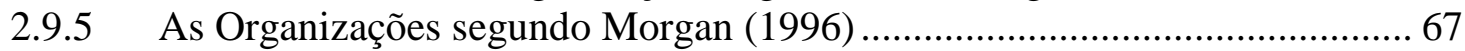

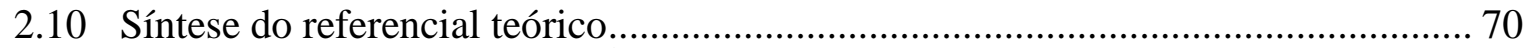

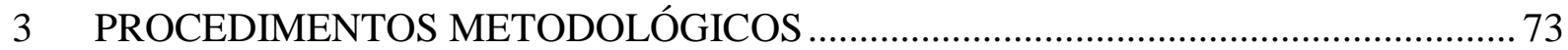

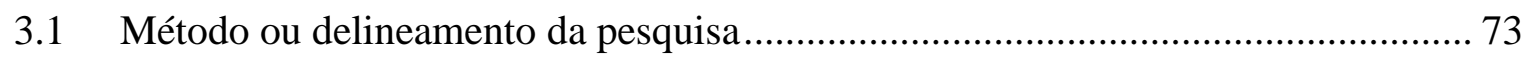

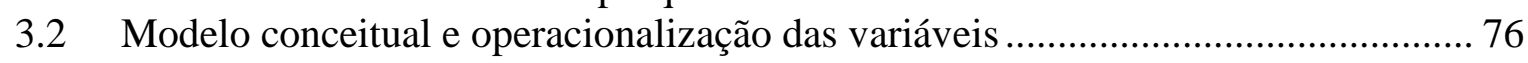

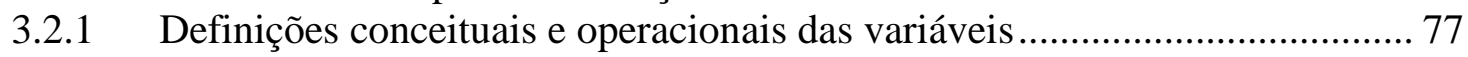

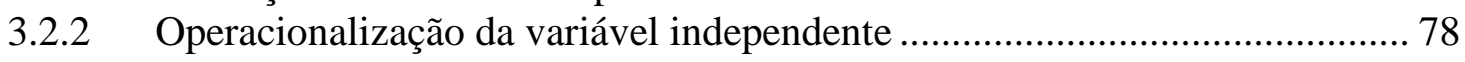

3.2.3 Operacionalização da variável dependente ............................................... 80

3.2.4 Operacionalização da variável moderadora ............................................ 81

3.3 Universo da pesquisa, seleção dos casos e da unidade de análise .......................... 81

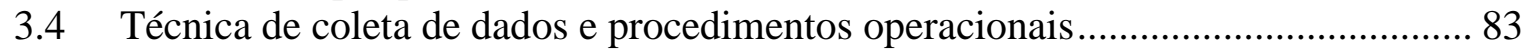

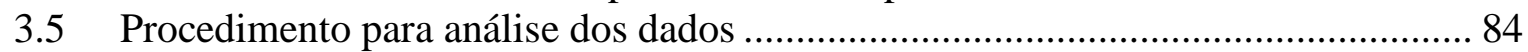

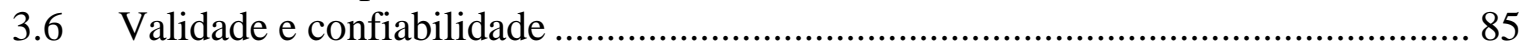

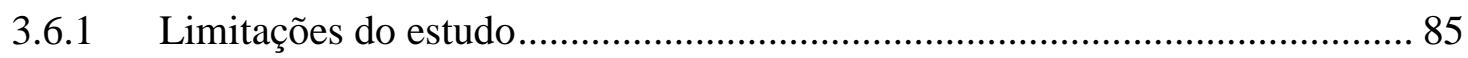




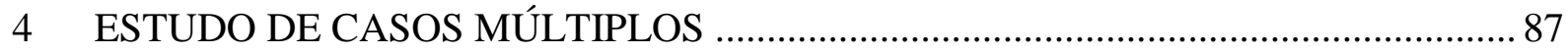

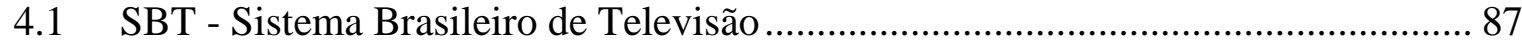

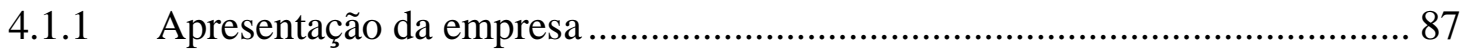

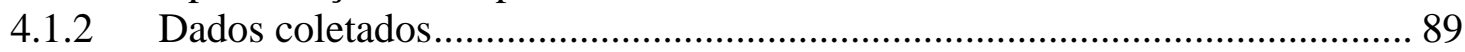

4.1.3 Como a organização desenvolve o planejamento estratégico ......................... 90

4.2 Granero Transportes Ltda................................................................................. 92

4.2.1 Apresentação da empresa ........................................................................... 92

4.2.2 Dados coletados........................................................................................... 93

4.2.3 Como a organização desenvolve o Planejamento Estratégico ......................... 93

4.3 Análise e resultados sobre o processo de desenvolvimento do planejamento estratégico no modelo de empresa empreendedora............................. 94

4.4 Owens-IIIinois do Brasil embalagens de vidro ………………………………...... 95

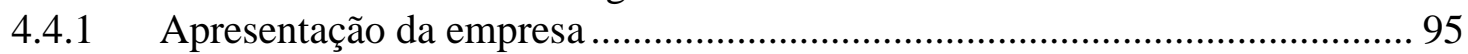

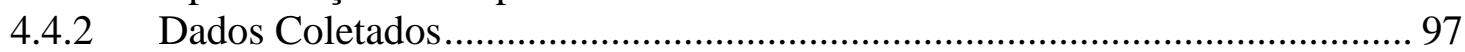

4.4.3 Como a organização desenvolve o Planejamento Estratégico ……………..... 97

4.5 EMBRAER Empresa Brasileira de Aeronáutica S.A. A............................................ 98

4.5.1 Apresentação da empresa ..................................................................... 98

4.5.2 Dados coletados................................................................................... 99

4.5.3 Como a organização desenvolve o Planejamento Estratégico ........................ 99

4.6 Análise e resultados sobre o processo de desenvolvimento do planejamento estratégico no modelo de empresa tipo máquina ………………….. 102

4.7 Fundação Armando Alvares Penteado.................................................................... 103

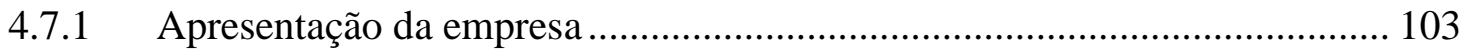

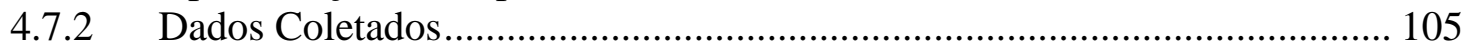

4.7.3 Como a organização desenvolve o planejamento estratégico ....................... 105

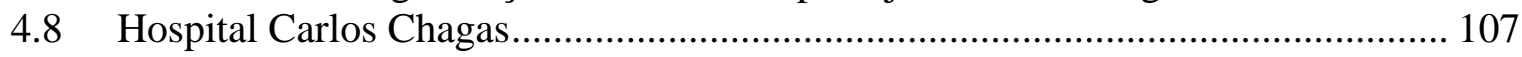

4.8.1 Apresentação da empresa ........................................................................ 107

4.8.2 Dados coletados..................................................................................... 108

4.8.3 Como a organização desenvolve o planejamento estratégico ........................ 108

4.9 Análise e resultados sobre o processo de desenvolvimento do planejamento estratégico no modelo de empresa tipo profissional ......................... 110

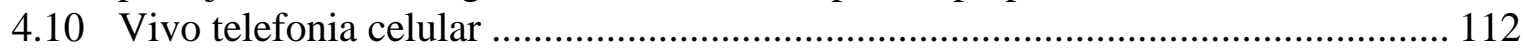

4.10.1 Apresentação da empresa .................................................................... 112

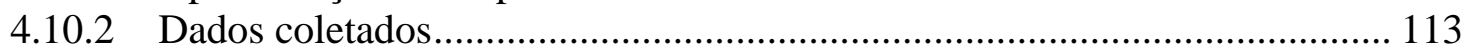

4.10.3 Como a organização desenvolve o Planejamento Estratégico ...................... 113

4.11 F/Nazca Saatchi \& Saatchi agência de publicidade................................................ 115

4.11.1 Apresentação da empresa ...................................................................... 115

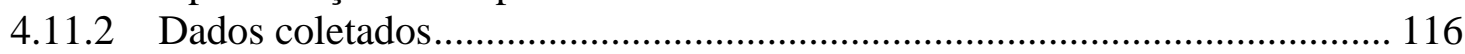

4.11.3 Como a organização desenvolve o planejamento estratégico ........................ 116

4.12 Análise e resultados sobre o processo de desenvolvimento do planejamento estratégico no modelo de empresa tipo inovadora ............................ 118

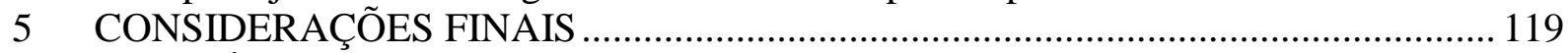

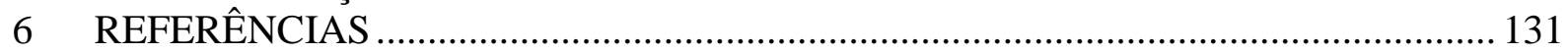

Bibliografia Consultada 


\section{LISTA DE ABREVIATURAS E SIGLAS}

BSC: Balance Score Card

CBG: Boston Consulting Group

EUA: Estados Unidos da América

FAAP: Fundação Armando Alvares Penteado

GE: General Eletric

MBO: Management by Objectives

MEC: Ministério da Educação

ONA: Organização Nacional de Saúde

PIMS: Profit impact of market strategies

RBV: Visão baseada em recursos (Resource based view) 



\section{INTRODUÇÃO}

\subsection{Contextualização e caracterização do tema}

O tema organização, seu papel na sociedade, sua evolução e as ferramentas utilizadas desde seu surgimento, sempre foi discutido entre pesquisadores e profissionais da área das Ciências Sociais.

O conceito de organização vem evoluindo ao longo dos anos. Mas é certo considerar a organização como uma unidade econômica, um conjunto organizado com finalidade de exercer uma determinada atividade. Para entender esta evolução é importante considerar as principais fases na história. De acordo com Heilbroner (1996), a fase artesanal que vai até 1780 tem início no mundo com a própria história do homem, devido à necessidade de se produzir bens para seu próprio uso. $\mathrm{O}$ artesanato foi a primeira forma de produção industrial, surgiu no fim da idade média, onde o produtor produzia em casa com sua família, o artesão realizava todas as etapas da produção. No século XI, o artesanato ficou concentrado em lugares conhecidos como oficinas, onde um grupo de aprendizes viviam com o mestreartesão, criador de todo o conhecimento técnico. Ele ensinava em troca de mão-de-obra barata, recebendo ainda vestimentas, comida e conhecimento. A partir daí surgem as Corporações de Ofício, organizações que os mestres de cada cidade ou região formavam, visando seus interesses, surgindo assim as pequenas organizações em que o sistema de comércio era de troca por troca.

A fase da Industrialização e desenvolvimento Industrial, de 1780 até 1914, inicia-se com a substituição de ferramentas por máquinas, base para a Revolução Industrial. Revolução esta devido ao conflito da sociedade; dando início a uma transformação de evolução tecnológica. Foi a partir da Revolução Industrial que surgiram as primeiras indústrias, assumindo um papel essencial no desenvolvimento da sociedade. Estas adotaram o método burocrático, com ênfase na departamentalização funcional, com a intenção de disciplinar e organizar o comportamento dos operários. Com o advento do motor de explosão e do motor elétrico, foi formada uma relação entre a ciência e o avanço da tecnologia das empresas. Devido a esse avanço foram criados os meios de transportes, facilitando a comunicação com diversos lugares, tendo assim um desenvolvimento rápido do intercambio comercial. 
No Gigantismo, de 1914 até 1945, tem-se a migração da população das áreas agrícolas para as proximidades das empresas provocando a urbanização. $\mathrm{O}$ capitalismo industrial começa a dar lugar ao capitalismo financeiro, surgindo assim os bancos e as instituições financeiras.

Na Modernização, de 1945 até 1980, as empresas atingem grandes proporções, passando a atuar no mercado internacional e multinacional. Ampliações nos meios de comunicação, como rádio e televisão, criam um mundo cada vez menor e mais complexo. Há uma notória separação entre os países desenvolvidos, os subdesenvolvidos e os em desenvolvimento. Os consumidores passam a ser em maior número e mais exigentes. Começa então uma competição entre as organizações com o intuito de satisfazer os clientes e ampliar os mercados (HEILBRONER, 1996).

A Globalização, de 1990 até 2000, nasceu da associação da tecnologia de informática com a tecnologia de comunicação e com a queda de barreiras comercias, criando assim uma interligação dos mercados internacionais. A fase da globalização foi marcada por desafios, dificuldades, ameaças e restrições para as organizações, foi um momento de incertezas e de acirrada concorrência. A globalização é um fenômeno mundial, onde tudo ocorre muito rápido, o desenvolvimento e intensificação da tecnologia da informação e dos transportes fazem do mundo uma aldeia global.

A partir de 2000 tem-se a organização sem barreiras físicas e a tecnologia da informação criou novas oportunidades e desafios para todos os tipos de organizações com possibilidade de comunicação instantânea cobrindo seus limites de atuação, processamento de grandes quantidades de informação e automatização do processo decisório. $\mathrm{O}$ ambiente tornou-se complexo e, permanecer neste ambiente passa a ser um grande desafio para qualquer organização.

Procurando avançar nessa discussão e trazer uma contribuição, não só para as empresas brasileiras, mas principalmente para a academia que necessita de trabalhos consistentes e atualizados, desenvolveu-se neste trabalho um estudo que focando o processo de desenvolvimento do planejamento estratégico nos modelos organizacionais.

O processo de desenvolvimento do planejamento estratégico está relacionado a um composto de ações, passos, análises e decisões inter-relacionadas e interdependentes que visam ao alcance de objetivos previamente estabelecidos. A maioria destas etapas no processo de desenvolvimento do planejamento estratégico apresentado por autores como Fischmann e 
Almeida (1991), Almeida (1997, 2003 e 2004), Thompson e Strickland (2000), Wrigth et al (2000), Hitt et al (2002 e 2008), Heijden (2005), Certo et al (2005), Mintzberg (2004 e 2006), Almeida e Benny (2007) e Kluyver e Pearce (2007), descrevem as devidas análises e passos do planejamento estratégico, mas não os diferenciam nos modelos organizacionais.

Como modelos organizacionais têm-se interpretações de diferentes aspectos que coexistem e complementam-se dentro da realidade organizacional, estabelecidos nos trabalhos de autores como, Mooney (1947), Blau e Scott (1970), Etzioni (1974), Mintzberg (1979 e 2006), Morgan (1996) dentre outros.

Os modelos organizacionais adotados neste trabalho serão melhores conceituados na revisão da literatura, porém pode-se adiantar que os mais citados e em comum acordo com os autores que os conceituaram são, organizações tipo:

- Empreendedora, centralizada no empreendedor que a fundou.

- Máquina, processos padronizados funcionando como máquinas integradas.

- Profissional, dependem da habilidade dos profissionais que nelas trabalham.

- Inovadora ou Adhocrática, baseada em projetos e grupos de especialistas.

Para o processo de desenvolvimento do planejamento estratégico deve-se passar pela etapa da administração estratégica. Harrison (2005) e Certo e Peter (2005) definem a Administração Estratégica como o processo pelo qual a organização analisa e aprende com seus ambientes internos e externos, estabelece a direção estratégica, cria estratégias que pretende movê-la naquela direção e programa essas estratégias, tudo em um esforço para satisfazer seus principais públicos interessados.

Deve-se levar em consideração, dentro da amplitude no processo de desenvolvimento do planejamento estratégico, a busca do equilíbrio entre eficiência e eficácia, melhor utilização dos recursos, realização dos objetivos e permanência por mais tempo no ambiente de negócios. Vico Manãs (2007) relaciona a realização de planos ao saber antecipadamente o que fazer, a qualquer momento, a curto ou longo prazo e não somente a algo formalizado, burocrático com determinados objetivos e cronogramas, considera o ato de pensar como fundamental no processo do planejamento estratégico. 
Outro aspecto importante para se entender o processo de desenvolvimento do planejamento estratégico, é relacioná-lo às visões que foram evoluindo no contexto do ambiente das organizações. A perspectiva preponderante em administração estratégica tem-se preocupado com a análise do ambiente em que a empresa está inserida e, em como a empresa deve posicionar-se em relação às forças desse ambiente competitivo, o que se pode chamar de orientação de fora para dentro, com abordagens muito discutidas e citadas na maioria dos artigos científicos com os trabalhos de Porter (1980, 1985, 1989, 1999, 2000, 2005), do modelo das cinco forças, de grande importância para a análise do ambiente competitivo e de como as empresas podem melhor lidar com esse ambiente. A abordagem de Porter (1980), porém apresenta algumas limitações importantes:

- Há um excesso de ênfase no ambiente externo na abordagem, ou seja, tira a criatividade dos executivos para alternativas de criatividade ou inovação, pois devem jogar como o mercado determina.

- A estrutura das cinco forças, não leva em consideração o fato de alianças da empresa com fornecedores, clientes, canais de distribuição ou concorrentes, restringindo as possibilidades de novos modelos produtivos (FLEURY; OLIVEIRA JR., 2001).

Outros trabalhos de autores como Chandler (1962), Williamson (1975, 1985), Christensen e Montgomery (1981) merecem destaque no desenvolvimento do planejamento.

Mesmo com estes autores e muitos outros desenvolvendo trabalhos dentro da linha de pensamento na abordagem externa, as lacunas na administração estratégica e, por sua vez, a evolução do pensamento no processo de desenvolvimento do planejamento estratégico, têm sido supridas pelas abordagens mais recentes da chamada visão de dentro para fora, Resource Based View (RBV), visão da empresa baseada em recursos, com ênfase nas competências a partir dos recursos intangíveis, que passam a ser mais estrategicamente relevantes para a empresa e que por isso devem ser cultivados, com trabalhos de Wernerfelt (1984), Barney (1986, 1991, 1997), Mahoney e Padian (1992), Hall (1993) e Barney e Hesterly (2008). Sob essa visão, os recursos podem ser pensados como um ponto forte ou um ponto fraco da empresa, ou como aqueles ativos tangíveis ou intangíveis que estão associados à empresa. Exemplos de recursos dentro desta perspectiva: pessoas qualificadas, dinâmicas das equipes de trabalho, estrutura organizacional, modelo de avaliação organizacional, sistemas de informação, componentes estratégicos difíceis de imitar entre outros. 
Essa abordagem pode ser entendida como uma tentativa de explicar e prever por que algumas empresas são capazes de estabelecer posições de vantagem sustentável. A visão da empresa baseada em recursos percebe a empresa como um conjunto de recursos e capacidades que juntos têm a tarefa de maximizar valor por meio de desenvolvimento ótimo dos recursos que vão construir a base para o desenvolvimento da empresa em longo prazo.

A compilação de autores como Penrose (1959), Rumelt (1984), Prahalad e Hamel (1990), Peteraf (1993) e Barney (1997) e Barney e Hesterly (2008), mostra que a necessidade de um recurso que seja difícil de: imitar, transferir, comprar, vender ou substituir e que possua uma integração sistêmica com outros recursos da empresa é a principal contribuição da visão da empresa baseada em recursos para a formulação sobre o desenvolvimento e sustentação de uma vantagem competitiva. Entender a empresa como conjunto de recursos é uma abordagem que proporciona ao pesquisador e profissional a possibilidade de identificar e desenvolver os recursos que serão significativos para o desempenho superior da empresa, colocando assim um fator importante nesta tarefa.

A proposta deste trabalho limita-se a verificar as etapas e análises dentro das visões descritas, estruturas, modelos de avaliação ou estabelecer e consolidar os passos para o processo de desenvolvimento nos diferentes modelos organizacionais, gerando um maior conhecimento de como estas organizações lidam com o planejamento estratégico ou desprezam etapas e análises. Existe um gap teórico que não explica como diferentes modelos tratam, elaboram e mesmo utilizam o gerenciamento dos seus recursos mediante as alterações do ambiente, base do processo de desenvolvimento do planejamento estratégico.

\subsection{Situação problemática}

Um problema pode ser definido tanto a partir da observação na prática, como na reflexão que se faz da teoria, ou ainda, pela aplicabilidade de um método que se queira testar. No contexto de um projeto de prática profissional, um problema é uma situação não resolvida, mas também pode ser a identificação de oportunidades até então não percebidas pelas organizações ou o interesse de uma preocupação acadêmica (ROESCH, 2007).

Partindo de uma observação nas organizações brasileiras, constatou-se que não foi possível identificar dados primários ou secundários que associassem o processo de desenvolvimento 
do planejamento estratégico aos modelos organizacionais estabelecidos. Outro fator observado foi a abordagem generalista deste processo, ou seja, como se um roteiro préestabelecido pudesse ser utilizado para qualquer tipo de organização. A partir daí levanta-se o problema de estudo: como o modelo organizacional caracterizado em uma empresa influencia o processo de desenvolvimento do planejamento estratégico?

Tem-se como limite, trabalhar com organizações privadas, pois as públicas têm, na sua maioria, fortes direcionamentos políticos. O objeto de estudo é a organização e não o indivíduo ou o grupo. Não se pretende analisar relações de competitividade entre os modelos nem entre características diferentes de organizações. Não foram analisadas microempresas por se entender que a maioria trabalha com visões de curto prazo ou sem desenvolvimento de planejamento estratégico.

Muitas organizações podem apresentar modelos híbridos, neste caso optou-se por aquele que tem a maior predominância ou a amostra foi descartada.

Como citado anteriormente, os modelos analisados foram: organizações tipo empreendedora, máquina, profissional, inovadora ou adhocrática.

Os critérios para caracterizar os modelos organizacionais serão explicitados na revisão da literatura e na metodologia.

\subsection{Objetivos}

Objetivo Geral:

Explicar os processos de desenvolvimento do planejamento estratégico, em diferentes modelos organizacionais, identificando as relações do modelo organizacional com o processo de desenvolvimento do planejamento estratégico.

\section{Objetivos Específicos:}

- Estabelecer, discutir e consolidar as etapas, análises e passos para o processo de desenvolvimento do planejamento estratégico.

- Caracterizar os modelos organizacionais definindo os atributos para cada modelo. 
- Identificar as relações do processo de desenvolvimento do planejamento estratégico em cada modelo organizacional.

- Analisar as relações entre o processo de desenvolvimento do planejamento estratégico e os modelos organizacionais.

- Propor uma estrutura (frame) diferente ou ajustada da atual relação entre o processo de desenvolvimento de planejamento estratégico e os modelos organizacionais escolhidos.

\subsection{Proposições}

Harrison (2005) estabelece três perspectivas da Administração Estratégica que influenciam o planejamento. A perspectiva tradicional, ou a visão de fora para dentro com ênfase na análise do ambiente. A perspectiva da visão baseada em recursos, ou de dentro para fora e a perspectiva dos públicos interessados, que adaptadas tendem as evidências de que as organizações podem desenvolver seu planejamento com visões que seguem as proposições:

P1: Organizações tipo empreendedora tendem a visões de curto prazo ou sem desenvolvimento do planejamento.

P2: Organizações tipo máquina tendem a desenvolver o planejamento considerando a visão de fora para dentro.

P3: Organizações tipo profissional tendem a desenvolver o planejamento considerando os públicos interessados.

P4: Organizações tipo inovadora ou adhocrática tendem a desenvolver o planejamento considerando a visão de dentro para fora.

Desta forma podem-se relacionar os levantamentos da revisão da literatura as proposições elaboradas. 


\section{$1.5 \quad$ Justificativa do projeto}

Quanto à oportunidade, tem-se para as organizações, um estudo que pode ajudar a entender o processo de desenvolvimento do planejamento estratégico e sua relação com modelos organizacionais, dando um perfil das tendências atuais e possivelmente uma estrutura (frame) diferente do que se conhece na literatura.

É comum oferecer para as organizações etapas prontas para formulação de planos, sem se considerar variáveis importantes como à tipologia da organização, que de certa forma influencia seu modo de agir, de lidar com seus recursos, de analisar seus concorrentes ou ambientes e até de gerenciar a tomada de decisão.

\subsection{Viabilidade do projeto}

Dentro do prazo estabelecido para finalização do projeto, a saber, no máximo dois anos, foi possível ter acesso a pelo menos duas organizações de cada tipologia dos modelos definidos, totalizando oito organizações, para verificar se há coincidência dentro de cada modelo no processo de desenvolvimento do planejamento estratégico e para se chegar com consistência nos objetivos estabelecidos.

As organizações foram caracterizadas nos modelos e escolhidas de acordo com a metodologia estabelecida.

\section{Importância do projeto}

Para justificar a importância para o meio acadêmico e empresarial, a questão não é apenas importar um modelo de administração como um modismo ou algo assemelhado, mas sim determinar os pré-requisitos básicos para se ter aproveitamento ótimo de todos os benefícios oferecidos por uma inovação em termos de ferramenta administrativa.

Assim, quanto à importância, no meio acadêmico tem-se para o futuro pesquisador um trabalho atualizado sobre como lidar com diferentes modelos organizacionais não só no processo de desenvolvimento do planejamento estratégico, mas na implantação e desenvolvimento de projetos, treinamentos, consultorias, seleção e colocação de colaboradores assim como um melhor entendimento para negociação com financiadores e terceiros. 
Para o gestor que desejar avaliar sua organização, vários atributos foram estipulados de acordo com a revisão bibliográfica, trazendo contribuições capazes de gerar ações para o mercado no qual sua organização compete, pois o diagnóstico da empresa dentro dos conceitos atuais valoriza muito o conhecimento da organização como um todo.

O trabalho foi composto por cinco partes, a saber, na primeira foi definida a questão problema, objetivos e proposições, na segunda, a revisão da literatura abordará o conceito de estratégia e etapas para o processo de desenvolvimento do planejamento estratégico, desde a visão de fora para dentro até os conceitos mais atuais da conhecida visão de dentro para fora, com ênfase nos recursos intangíveis. Posteriormente o contexto das organizações evoluindo para os modelos organizacionais, com uma síntese da revisão de literatura ao final. A terceira parte refere-se à metodologia.

A quarta parte é destinada á análise e resultados da proposta do trabalho, a partir do estudo de casos múltiplos, com o entendimento do fenômeno estudado.

$\mathrm{Na}$ quinta e última parte foram desenvolvidas as sugestões para o desenvolvimento do planejamento estratégico nos modelos organizacionais escolhidos e propostas para prosseguimento do estudo. 



\section{REVISÃO DA BIBLIOGRAFIA}

\subsection{O conceito de estratégia e sua evolução}

Para chegar ao processo de desenvolvimento do Planejamento Estratégico, faz-se necessário uma contextualização da estratégia e suas linhas de pensamento, a partir da sua evolução e ligação com o propósito maior do projeto, não se pretende analisar estas linhas de pensamento, porém deixar claro que as organizações consideram algumas informações que pertencem a visões diferentes.

Na década de 1930, Barnard apud Ghemawat (2000), executivo da New Jersey Bell, afirmou que os gerentes deveriam prestar atenção aos "fatores estratégicos", que dependem de ações pessoais ou organizacionais.

O pensamento estratégico foi articulado, inicialmente, na alta gerência, Sloan (1963) executivo principal da GM em meados da década de 1950, criou uma estratégia bem sucedida baseada em forças e fraquezas identificadas da sua maior concorrente, a Ford.

A Segunda Guerra Mundial, devido aos problemas de recursos escassos, forneceu um grande estímulo ao pensamento estratégico. No início dos anos 1950, professores de Política de Negócios da Escola de Harvard, Smith e Christensen (1951), incentivaram os alunos a perguntar se a estratégia de uma empresa se adequava ao seu ambiente competitivo. Nos anos 1960, as discussões nas escolas de administração começaram a focalizar a combinação das forças e fraquezas de uma empresa, sua competência distintiva, e as oportunidades e ameaças, estrutura que veio a ser conhecida pela sigla "SWOT", strengths - pontos fortes, weaknesses pontos fracos, opportunities - oportinidades e threats - ameaças, importante passo para tratar de questões estratégicas. Este conceito foi difundido pela conferência sobre política de negócios em Harvard em 1973.

Ansoff (2001) sugeriu quatro categorias para se definir a linha de negócios/corporativa, codesenvolvimento de sua matriz produto/mercado e também se esforçou para traduzir a lógica embutida na estrutura “SWOT”. Nos anos 1960 e início dos anos 1970, presencia-se a ascensão de várias empresas de consultoria de estratégia, a mais conhecida e utilizada ainda hoje, principalmente no meio acadêmico, o Boston Consulting Group (BCG), com a curva de experiência e a análise de Portfólio, ou matriz crescimento-participação. Outras consultorias 
desenvolveram suas matrizes como McKinsey, Arthur D. Little e empresas passaram a adaptálas de forma direcionada às suas necessidades como a General Electric (GE).

Porter (1980) publica seu primeiro livro, Competitive Strategy, o qual deve grande parte do seu sucesso à sua estrutura de cinco forças.

O tema estratégia tem gerado muita discussão e muitos recursos para o que se pode chamar de business industry, indústria dos negócios. Porém, de acordo com Porter (1980, 1985, 1989 e 1999) muitas vezes a estratégia adotada não é clara e isto leva a uma situação de não posicionamento. Fica claro que, para a maioria das organizações, a visão de estratégia, mesmo que para um discurso de racionalidade, é quase nula. Para entender a evolução desta visão, é interessante colocar seu desenvolvimento que se pode dizer começou também a partir da segunda revolução industrial, pois a primeira não produziu muito em termos de pensamento ou comportamento estratégico. No final do século XIX, começou a emergir um novo tipo de empresa, inicialmente nos Estados Unidos da América (EUA) e depois na Europa, a grande empresa verticalmente integrada que investia em manufatura e marketing. Estas empresas começaram a alterar o ambiente competitivo em suas indústrias e até mesmo a ultrapassar limites entre indústrias (CHANDLER,1990).

No campo da administração de empresas, a estratégia pode ter diversos significados: longo prazo, ambiente, planejamento, padrão, perspectivas, concorrência, recursos e outros termos que aos poucos foram sendo formulados e agregados ao moderno vocabulário da Administração. No Quadro 1 as principais definições, resumidas, são examinadas.

Tem-se pelo exposto no Quadro 1 que os primeiros autores que tratavam da estratégia enfatizam a importância do processo de planejar objetivos em sintonia com as ameaças e as oportunidades oferecidas pelo ambiente, pouco se trabalhava com recursos internos ou ativos intangíveis.

Diante da evolução dos conceitos sobre estratégia percebe-se que esta se relaciona à obtenção de vantagens competitivas que para Porter (1980), Ohmae (1985), Ansoff (2001), Barney e Hesterly (2008) estão relacionados a diferenciais sustentáveis no longo prazo e que, de certa forma, sejam percebidos pelo mercado e pelos clientes. Ou quando uma empresa cria mais valor econômico que suas rivais. O processo de desenvolvimento do planejamento estratégico bem definido ajuda as organizações a identificarem suas vantagens, desvantagens ou mesmo paridades competitivas, facilitando a tomada de decisão e direcionamento estratégico para atingirem objetivos pré-estabelecidos. 
Quadro 1 - Definição de estratégia segundo diversos autores

\begin{tabular}{|c|c|}
\hline Autor & Conceitos-Chaves \\
\hline Chandler (1962) & $\begin{array}{l}\text { Determinação de metas básicas em longo prazo e dos objetivos de uma empresa e } \\
\text { a adoção das linhas de ação e aplicação dos recursos necessários para alcançar } \\
\text { essas metas. }\end{array}$ \\
\hline Ackoff (1974) & $\begin{array}{l}\text { Estratégia está relacionada à mobilização de todos os recursos e políticas da } \\
\text { organização em âmbito global, visando atingir objetivos e comportamentos em } \\
\text { longo prazo. }\end{array}$ \\
\hline Porter (1980) & $\begin{array}{l}\text { Estratégia (competitiva) diz respeito a ser diferente. Significa deliberadamente } \\
\text { escolher um conjunto diferente de atividades para entregar um mix único de valor. }\end{array}$ \\
\hline Ohmae (1985) & $\begin{array}{l}\text { Modo pelo qual a empresa procura distinguir-se de maneira positiva da } \\
\text { concorrência, usando seus pontos fortes para atender melhor às necessidades dos } \\
\text { clientes. }\end{array}$ \\
\hline Hampton (1986) & $\begin{array}{l}\text { Vantagens da empresa em relação aos desafios do ambiente, adaptação da } \\
\text { empresa ao ambiente. }\end{array}$ \\
\hline Mintzberg (1987) & $\begin{array}{l}\text { Relaciona estratégia a: } \\
\text { - Estratégia como plano para o futuro } \\
\text { - Estratégia como um padrão de comportamento } \\
\text { - Estratégia como posição de produtos ou mercados } \\
\text { - Estratégia como perspectiva ou forma de fazer as coisas } \\
\text { - Estratégia como uma manobra do poker para enganar um oponente }\end{array}$ \\
\hline Pascale (1994) & $\begin{array}{l}\text { Processo de selecionar oportunidades, definidas em termos de encomendas a } \\
\text { serem atendidas e produtos a serem oferecidos e, ao mesmo tempo, tomar } \\
\text { decisões sobre investimentos de recursos com a finalidade de atingir objetivos. }\end{array}$ \\
\hline Ansoff (2001) & $\begin{array}{l}\text { Estratégia de carteiras relacionadas ao negócio em que estamos, às tendências que } \\
\text { ocorrem, decisões sobre os negócios do futuro. }\end{array}$ \\
\hline & Estratégia Competitiva relacionada à diferenciação de produtos ou mercado. \\
\hline Barney e Hesterly (2008) & $\begin{array}{l}\text { Estratégia é definida a partir da sua teoria de como obter vantagens competitivas } \\
\text { ou um conjunto de suposições e hipóteses sobre como a competição no setor } \\
\text { tende a evoluir e pode ser explorada. }\end{array}$ \\
\hline
\end{tabular}

As visões relacionadas a seguir, têm influencia nas etapas, análises e passos para o processo do planejamento estratégico, assim cabe um entendimento melhor de sua evolução e desenvolvimento para associá-las aos modelos organizacionais.

\subsection{Análise estrutural da indústria, base para a visão de fora para dentro}

Os trabalhos de Porter (1980, 1985, 1989 e 1999) têm forte influência no desenvolvimento e aprimoramento na visão de fora para dentro. Para o autor as indústrias têm em cada uma delas suas peculiaridades econômicas, posicionamento de mercado e projeção do futuro. O ritmo da mudança na tecnologia pode ser rápido ou lento. As necessidades de investimento e capital podem ser variadas, de muito a pouco. Quanto ao mercado ele pode ser regional ou mundial. Os produtos podem ser padronizados ou altamente customizados. A concorrência pode ser forte ou fraca, com diferentes posicionamentos de preço, qualidade, serviço, promoção e outras variáveis competitivas. 
O cenário industrial pode ser tão volátil, que as empresas líderes em indústrias pouco atrativas podem ter dificuldades para obter lucros importantes, enquanto que empresas fracas em indústrias atrativas podem ter um bom desempenho. Além disso, as condições da indústria mudam e se desenvolvem à medida que vários aspectos que definem o ambiente do negócio aumentam ou diminuem sua influência.

A análise da indústria e da competitividade utiliza um conjunto de ferramentas de conceitos e metodologias para estabelecer um parâmetro sobre as condições que se alteram na indústria e sobre a natureza e intensidade das forças competitivas. Esse conjunto forma uma maneira de refletir estrategicamente sobre a situação geral de qualquer indústria e tirar conclusões sobre a possibilidade da indústria fazer ou não um investimento atrativo para o capital.

As indústrias são muito diferentes entre elas. A análise da indústria e competitividade começa com uma revisão completa do perfil econômico principal da indústria.

De acordo com Porter (1980), tais fatores devem ser padronizados, favorecendo uma comparação precisa, alguns destes fatores:

- Tamanho do mercado.

- Atuação da concorrência, local, regional, nacional ou global.

- Taxa de crescimento do mercado e papel da indústria no crescimento.

- Número de rivais e seu porte.

- Número de compradores e seu porte.

- Facilidade de entrada e saída.

Existem outros fatores que podem ser aplicados ou não conforme o nível de detalhe desejado, até conseguir um nível confortável de informações para tomar uma decisão mais precisa. Bethlem (1998) coloca a importância da interpretação destes fatores, que podem variar de acordo com o tempo, ou seja, na maioria das vezes não é em tempo real e dependem do indivíduo que as colheu. Toda interpretação e descrição dos fatores, feitas pelo mesmo observador em momentos diferentes, pode interpretar e descrever de forma diferente o mesmo fenômeno ou evento. 
Os conceitos mais conhecidos e discutidos na base da visão de fora para dentro vêm das cinco forças competitivas:

- Concorrentes potenciais.

- Poder dos fornecedores.

- Poder dos compradores.

- Produtos substitutos.

- Rivalidade entre os concorrentes diretos.

Assim como o conceito de tipos de estratégias consideradas genéricas: custo, diferenciação e foco, e a estrutura da cadeia de valor. Estas abordagens foram amplamente discutidas e comentadas, sendo Porter o autor mais citado no meio acadêmico e organizacional (RODRIGUES e NAVARRO, 2004).

A análise do ambiente competitivo exige uma avaliação da intensidade de cada uma das cinco forças competitivas. O impacto conjunto dessas forças determina a intensidade da concorrência em uma indústria. De maneira geral, quanto maior a força de competição no setor, mais estreito será o caminho em relação à lucratividade.

A forma mais forte de concorrência em um setor ocorre quando os competidores se dispõem a passar um período longo tendo margens de lucro negativas e cuidadosamente dimensionadas, com objetivo de ganhar maior presença no mercado e minar seus concorrentes. Esse conjunto de fatores deixa a indústria pouco atrativa pelos lucros baixos, principalmente se as barreiras de entrada forem porosas, altas ofertas de produtos substitutos e quando os fornecedores tiverem um poder de barganha grande.

É preciso que a empresa esteja bem atenta para as movimentações e projeções de cada um dos fatores, e que os apliquem no contexto de sua administração estratégica.

Outros trabalhos também ajudaram a desenvolver a visão de fora para dentro e são importantes para entender suas evoluções, dentre eles têm-se as obras de Chandler (1962 e 1990) e outros autores. 


\subsubsection{A importância das estratégias de escala e escopo no desenvolvimento da visão de fora para dentro}

Scale and Scope, junto com outros trabalhos de Clandler (1962 e 1990) relatam uma consistente análise de negócios organizacionais, desenvolvimento industrial e o crescimento de empresas em grandes pólos econômicos como EUA, Inglaterra e Alemanha. Enquanto muito que se escreve sobre história de negócios pode ser considerado vago, Chandler (1990) provoca reflexões sérias sobre a riqueza das nações. Sua análise é rica em detalhes, e deixa claro que os negócios empresariais e seus gerentes não reagem meramente às forças do mercado e à tecnologia, mas eles dão o formato do desenvolvimento tecnológico e o sucesso no mercado. Organizações não são simplesmente agentes do mercado, ao contrário mercados são agentes das organizações. Ele não pode simplesmente ser entendido sem entender as estratégias e estruturas das empresas. Outros autores como Schumpeter (1942) e Gerschenkron (1953) também desenvolveram teorias sobre desenvolvimento econômico. A proposta do autor foi a comparação de países atrasados em relação aos mais avançados, não só com referência a estrutura financeira, mas também organização produtiva das indústrias. Há também muito em comum com Schumpeter na obra "Capitalismo, Socialismo, e Democracia". Como Schumpeter (1942), Chandler (1990) analisa organizações industriais grandes e sua importância ao desenvolvimento industrial. Ambos têm em comum uma visão de desenvolvimento industrial no qual organizações podem ser inovadoras e eficientes, no conceito de Schumpeter, uma economia competitiva apresenta novas combinações eliminando o velho. Ghemawat (2000) também lida com conceito de escala e escopo, porém pode-se afirmar que os estudos de Clandler são mais ricos em detalhes e ilustrações facilitando o entendimento do desenvolvimento organizacional e das organizações.

A escala está relacionada a volume, grandes quantidades e escopo a utilização de poucas matérias-primas para atender vários mercados. Chandler (1990), associa a evolução e permanência no ambiente as organizações que souberam utilizar estratégias de escala e escopo, diretamente ligado a uma estrutura funcional da Organização em ambientes estáveis e sem grandes mudanças internas. 


\subsection{A perspectiva da visão baseada em recursos, o conceito de dentro para fora}

A Visão Baseada em Recursos (RBV), ou Resource Based View, tem atraído a atenção de diversos pesquisadores, segundo Mahoney e Pandian (1992), por ser um modelo que encoraja o diálogo de diferentes perspectivas teóricas, em particular, interconecta três linhas importantes de pesquisa:

- Conceitos sobre a estrutura principal da estratégia.

- Economia organizacional.

- Organização industrial.

Quanto à estrutura da estratégia, a RBV incorpora as competências distintivas de organizações heterogêneas e as implicações de direção e desempenho de estratégias de diversificação, como novos produtos em novos mercados, integração vertical para frente e para traz, aquisição de concorrentes ou outras empresas que podem não pertencer ao negócio original.

Com relação à área de economia organizacional, a RBV adapta conceitos relativos à Teoria da Agência, Direitos de Propriedades, Custos de Transação e Economia evolucionária.

Com relação à organização industrial, Mahoney e Pandian (1992) afirmam ocorrer um forte alinhamento em relação ao modelo de Porter (1980) quanto à questão de sustentação competitiva por meio de mecanismos de isolamento que criam barreiras à mobilidade e a substituição. Para Foss (1997), a perspectiva RBV possui, inicialmente, duas generalizações empíricas básicas:

- Existem diferenças sistemáticas básicas entre as organizações, estendendo-se pela forma na qual elas controlam seus recursos para implantar suas estratégias e.

- Estas diferenças são relativamente estáveis.

A estrutura básica da RBV irá emergir quando estas duas generalizações forem combinadas com dois pressupostos derivados da economia: diferenças nos recursos das organizações causam diferenças de desempenho e, empresas procuram aumentar sua performance econômica. As implicações são que empresas buscam atingir desempenho superior por meio da aquisição de um conjunto de recursos que lhes gerem vantagens competitivas. 
Dentro destas premissas, Wernerfelt (1984) propõe o desenvolvimento de algumas ferramentas econômicas para analisar a posição dos recursos e, por esta análise, investigar possíveis posições estratégicas e a possibilidade de mensuração do resultado da relação entre lucratividade e recursos. Analisar a organização, em termos de recursos, traz: a) um novo olhar sobre sua posição estratégica diferente da análise por produto; b) ajuda identificar tipos de recursos que geram maior rentabilidade; c) auxilia na escolha entre explorar mais os recursos existentes ou aquisição de novos; e, d) aquisições passam a ser vistas por meio da compra de um feixe de recursos.

Seguindo a linha de Wernerfelt (1984), Rumelt (1984) defende que o conceito de posição competitiva de uma organização é definido pela cesta de recursos únicos detidos por esta e seus relacionamentos. E a tarefa da gerência é ajustar e renovar estes recursos e relacionamentos com o passar do tempo a fim de manter seu valor e a posição competitiva, tal posição também é defendida por Dierickx e Cool (1989) e Peteraf (1993).

Dentro da RBV deve-se enfatizar o processo de desenvolvimento interno dos recursos, o qual Dierickx e Cool (1989) designam por acumulação. Os recursos exigem um processo de acumulação contínuo, consistente, persistente, mas de esforços incertos. O trabalho destes autores é particularmente importante porque foca precisamente nos tipos de recursos e competências que são centrais a RBV: recursos não negociáveis que são desenvolvidos e acumulados pela organização. Estes recursos defendem a imitação porque possuem dimensões tácitas e são socialmente complexos, eles surgem dos conhecimentos e aprendizagem da organização.

A aquisição de recursos também é considerada um elemento-chave da RBV. Existem mercados de recursos estratégicos onde a organização adquire recursos para implantar suas estratégias. Estes mercados são imperfeitos, ao contrário da visão da economia neoclássica, e cabe a organização explorar estas imperfeições. O valor de mercado de cada recurso possui uma relação direta com o valor dele na estratégia da empresa, organizações que estão bem informadas sobre o valor futuro do ativo dentro de sua estratégia e conseguem tirar proveito disto adquirindo-o no mercado por um preço inferior ao seu retorno ou não o adquirindo quando está com preço superior ao seu retorno futuro, conseguirão em longo prazo retornos acima da média.

Portanto, é a consistência da análise interna da organização sobre o valor futuro dos recursos em sua estratégia que lhe dará vantagem competitiva através da aquisição destes recursos no mercado atual (BARNEY, 1986; BARNEY; HESTERLY, 2008). As informações sobre os 
recursos da organização permanecem como propriedades exclusivas, protegidas por mecanismos de isolamento. Desta forma, é a assimetria de informação relativa ao potencial dos recursos e competências específicas que devem guiar a estratégia, pois são as únicas fontes possíveis de vantagem competitiva.

Para facilitar a análise, por conveniência, os recursos podem ser classificados em três categorias: recursos físicos, recursos humanos e recursos organizacionais.

Os recursos físicos incluem tecnologia física, fábricas e equipamentos, localização geográfica e acesso a matérias-primas. Recursos humanos incluem treinamento, experiência, julgamento, inteligência, relacionamentos e "insights" dos gerentes e colaboradores. Recursos organizacionais incluem a estrutura organizacional formal, planejamento formal e informal, sistemas de coordenação, avaliação e controle, bem como relações informais entre grupos e entre a empresa e o ambiente (BARNEY, 1991; BARNEY; HESTERLY, 2008).

No entanto, é importante notar que nem todos os recursos são recursos estratégicos. Recursos estratégicos são aqueles que trazem vantagem competitiva, implantando uma estratégia de criação de valor que não é simultaneamente empregada por nenhuma outra empresa e, é capaz de sustentar a vantagem competitiva mantendo a estratégia da empresa isolada de cópia por outras empresas. Assim sendo, as empresas não podem esperar obter vantagem competitiva sustentável se os recursos empregados estão disponíveis a todas as empresas ou possuem alta mobilidade.

Para um recurso trazer vantagem competitiva sustentável, este deve ser: valioso, raro, difícil de imitar e não possuir equivalente estratégico. O recurso valioso é aquele que explora as oportunidades e neutraliza as ameaças do ambiente da organização. O recurso raro é aquele que é escasso e não presente em nenhuma empresa concorrente ou potencialmente concorrente. Estes atributos dos recursos da empresa servem como indicador da heterogeneidade da organização e da imobilidade de seus recursos e, portanto, quão útil os recursos detidos pela empresa geram vantagem competitiva e sustentam esta vantagem.

A principal ferramenta para se conduzir essa análise, considerada interna é chamada de modelo VRIO, onde "V" significa a questão do valor, "R" a questão da raridade, "I" de imitabilidade e "O" a questão da organização mediante suas políticas e procedimentos para dar suporte à exploração de seus recursos valiosos, raros e custosos para imitar (BARNEY, 1991; BARNEY; HESTERLY, 2008; PETERAF, 1993). 
Collis e Montgomery (1995), por meio da articulação de diversos argumentos da RBV, defendem que teoria dos recursos explica como os recursos dirigem a performance da empresa, em um ambiente competitivo combinando análises internas sobre a empresa com análises externas sobre o ambiente. O sucesso da organização advém da melhor e mais apropriada posse de recursos para seus negócios e estratégias. A organização deve realizar cinco testes para identificar o valor dos seus recursos: imitabilidade, durabilidade, apropriação, substituição e superioridade competitiva. Quanto à possibilidade de imitabilidade o teste para o recurso pode ser feito por:

- Unicidade física.

- Dependência de padrões (path dependence).

- Ambigüidade causal.

- Limitação potencial de mercado (economic deterrence).

O teste da durabilidade consiste em verificar como determinado recurso pode sustentar a performance ao longo do tempo. O teste da apropriação mede como o recurso é capaz de capturar rentabilidade do mercado. O teste da substituição verifica qual a possibilidade de outro tipo de recurso ser utilizado para realizar a mesma finalidade. E, por fim, o teste da superioridade competitiva verifica qual, realmente, é melhor para a organização. Os gerentes devem construir as estratégias de suas empresas tendo em vista estas cinco questões.

Neste sentido, a estratégia deve procurar criar mecanismos de difícil imitação, aproveitando condições históricas que favoreçam seu desenvolvimento. Porém, o papel da organização não é apenas o de alocação de recursos escassos entre finalidades alternativas, mas sim da gestão dos processos de acumulação, coordenação e difusão dos recursos que passam a ser a função primordial da administração de empresas para a performance competitiva (PRAHALAD; HAMEL, 1990).

Dentre os fatores que tornam difícil a imitação dos concorrentes, na perspectiva RBV, encontramse os fatores naturais, geografia, raridade de materiais, de mecanismos legais e institucionais: marca, patentes, reserva de mercado, direitos de propriedade, além de fatores econômicos e organizacionais. Estes fatores contemplam a natureza tácita dos recursos (REED; DEFILLIPPI, 1990), as condições históricas únicas do desenvolvimento dos recursos e competências (BARNEY, 1997; BARNEY; HESTERLY, 2008), a ambigüidade causal e a complexidade dos recursos (REED; DEFILLIPPI, 1990; BARNEY, 1997; BARNEY; HESTERLY, 2008). 
A imitação ou substituição aumenta o suprimento de um recurso inicialmente escasso, podendo reduzir a possibilidade de lucro da organização, o que leva à procura de proteção deste recurso contra a imitação. A capacidade de proteção de um recurso contra a imitação ou substituição, por sua vez, é uma questão dependente de uma série de outros fatores.

Rumelt (1984), Barney (1991) e Mahoney e Pandian (1992) descrevem esta proteção como mecanismos de isolamento, sendo eles, a indeterminação ou ambigüidade causal do conhecimento envolvido. A ambigüidade causal é dada pelo relacionamento de diversos recursos, ou seja, é um recurso resultante da interação de outros recursos e atividades e, portanto, não é copiado diretamente. Rumelt (1984) ainda adverte que uma indústria de alto crescimento, onde as taxas de rentabilidade são relativamente altas, as empresas não levam em consideração os mecanismos de isolamento, porém, quando a indústria atinge seu equilíbrio final, estas empresas que negligenciaram os mecanismos de isolamento passam a operar com retornos abaixo da média.

Na linha de Rumelt (1984) sobre ambigüidade causal, Reed e Defillippi (1990) propõem a existência de três condições que, individualmente ou em conjunto, levaria a ambigüidade causal: conhecimento tácito, complexidade decorrente da interdependência entre um grande número de recursos e, especificidade dos ativos. Devido à ambigüidade causal, as outras empresas ficam impossibilitadas de imitação porque elas não sabem qual deve ser a ação que devem tomar para imitar a estratégia da concorrente e, portanto, a estratégia não pode ser duplicada.

Além da ambigüidade causal existem outras formas de isolamento que estão descritos resumidamente no Quadro 2.

Quadro 2 - Formas de isolamento

\begin{tabular}{|l|l|}
\hline \multicolumn{1}{|c|}{ Referência } & \multicolumn{1}{c|}{ Formas de isolamento } \\
\hline Wernerfelt (1984) & Recursos como barreiras de posicionamento \\
Itami (1987) & Ativos Invisíveis \\
Dierickx e Cool (1989) & Recursos com limitada substituição estratégica por outros ativos \\
Barney (1991) & Recursos únicos ou raros que não são perfeitamente móveis \\
Dierickx e Cool (1989) & Recursos valiosos, não negociáveis ou imperfeitamente \\
Barney (1991) & negociáveis \\
Prahalad e Bettis (1986) & Competências essenciais que são difíceis de replicar \\
Prahalad e Hamel (1990) & \\
\hline
\end{tabular}

Entender como as Organizações conhecem ou definem suas formas de isolamento pode trazer uma contribuição valiosa no processo de desenvolvimento do planejamento estratégico, assim como a relação de sua cultura e competências. 


\subsubsection{Cultura e competências da visão baseada em recursos}

Dentro da visão da RBV, a cultura organizacional é um recurso que pode trazer vantagem competitiva para a empresa, conforme aponta Barney (1986). Organizações que possuem um forte conjunto de valores gerenciais, que definem como elas conduzem seus negócios, são formas de explicar como elas atingem performance financeira superior. Para sustentar desempenho superior a cultura de uma empresa, segundo Barney (1986), precisa possuir três características: ser valiosa, ou seja, permitir ações da empresa no sentido de se obter maiores vendas, maiores margens e retornos, etc.; ser rara, ou seja, possuir elementos incomuns as outras empresas com as quais compete; e, ser de difícil imitação não permitindo que outras organizações copiem seus elementos formadores. O autor adverte, ainda, que a cultura organizacional, que hoje é uma fonte de sustentação de vantagem competitiva, pode com a mudança do ambiente competitivo tornar-se uma fonte de fraqueza da empresa para enfrentar a concorrência.

Em um trabalho sobre competência central, Prahalad e Bettis (1986) constroem o conceito da lógica dominante, a partir da problemática do gerenciamento de unidades de negócio diversificadas agregando aspectos da psicologia cognitiva e utilizando as noções de "esquemas mentais". Ou seja, a unidade central ou corporativa por meio de seus sistemas de conhecimentos e crenças individuais toma decisões na alocação de recursos nas unidades de negócios. A questão central, colocada pelos autores, é porque algumas empresas conseguem boa performance em suas unidades de negócio diversificadas e outras empresas não. A resposta proposta é que a performance pode ser explicada pela forma que os gestores do negócio central definem como os recursos devem ser alocados na unidade de negócios. Segundo esta argumentação, o gestor de uma organização possui uma forma de ver o funcionamento "esquemas mentais", do mundo e propor ações apropriadas para as demandas que ele encontra e interpreta.

Esses esquemas mentais não são expressos de forma consciente e são desenvolvidos de acordo com a experiência do indivíduo, ou seja, a forma com que ele aprende a lidar com as situações a qual é exposto. O esquema mental compartilhado pela organização é à base da lógica dominante. Prahalad e Bettis (1986) argumentam que a performance tem relação com a capacidade do time gerencial de adquirir as competências requeridas pelas novas unidades de negócio, e não pela replicação simples da lógica de gerenciamento do negócio central. 
Prahalad e Hamel (1990) desenvolvem o conceito da competência central da corporação, ou competências essenciais, Core Competence. Os autores definem competência central como um aprendizado coletivo da organização, especialmente como coordenar diversas habilidades de produção e integrar múltiplas correntes de tecnologia. Segundo os autores, para serem essenciais, as competências devem responder a três critérios: uma competência central deve ser versátil e proporcionar acesso a uma ampla variedade de mercados; oferecer reais benefícios aos consumidores; e, ser difícil de imitar e prover acesso a diferentes mercados.

Uma competência central não é constituída por uma habilidade ou tecnologia isolada, mas sim, por uma complexa harmonização de múltiplas habilidades e tecnologias (PRAHALAD e HAMEL, 1990). O domínio de um determinado conjunto de competências centrais irá definir em quais produtos a empresa pode buscar participação no mercado com possibilidade de sucesso. Deste modo, a compreensão das competências centrais de um setor ou empresa atua não somente restringindo, mas também focalizando o horizonte de atuação competitiva deste setor ou empresa, adicionando à questão das decisões estratégicas uma nova dimensão de análise.

A corporação deve desenvolver uma arquitetura estratégica baseada na competência central que dê a lógica para a diversificação do produto e do mercado revelando uma direção ampla, mas sem revelar cada passo.

Todos estes estudos e argumentos formam a base para a evolução do conceito de fora para dentro, com ênfase no ambiente, para o conceito de dentro para fora, ênfase nos recursos. A partir destas bases vários atributos serão levantados para relacioná-los, principalmente às análises desenvolvidas nos modelos organizacionais definidos, e chegar aos objetivos específicos estabelecidos neste trabalho.

A seguir têm-se a importância de conhecer os conceitos relacionados ao processo de desenvolvimento do planejamento estratégico, como a evolução dentro das escolas do Planejamento, etapas e passos para sua elaboração. 


\subsection{O conceito de Planejamento Estratégico}

A palavra plano é de origem latina, planu, que significa superfície plana, lisa, sem desigualdades. Sua adoção para identificar planos formais está relacionada ao fato de no passado essas superfícies serem utilizadas para abrir mapas e relatórios (Mintzberg, 2004). Considerando apenas os sentidos relacionados ao planejamento estratégico, encontra-se plano como projeto ou empreendimento com fim determinado; conjunto de métodos e medidas para a execução de um empreendimento; documento que encerra um conjunto de ações governamentais a serem adotadas, visando determinado objetivo; arranjo ou disposição de uma obra. No sentido figurado pode significar intento, propósito, desígnio. Derivando de plano tem-se planejamento, que significa ato ou efeito de planejar; trabalho de preparação para qualquer empreendimento, segundo roteiro e métodos determinados; planificação; processo que leva ao estabelecimento de um conjunto coordenado de ações visando à consecução de determinados objetivos (FERREIRA, 1999).

Geus (1998) aborda que nesse período diversas ferramentas para prever o futuro foram desenvolvidas sob o nome genérico de planejamento, que o caracterizava como a busca por um redutor de incertezas e que nos anos de 1940 as empresas delegaram para as áreas de contabilidade e finanças esta tarefa.

Buscando aumentar a precisão das previsões, as empresas adotaram, nos anos 1960, a forma bottom-up, pelas quais os planejadores financeiros, desconectados do dia-a-dia dos mercados, consultavam o pessoal "de frente" antes de definir seus orçamentos. A partir desta colocação, segundo Geus (1998), para o gerenciamento por objetivos foi um passo. Vale lembrar que a gerência por objetivos já era defendida por Drucker (1986) nos anos de 1950.

Como muitas novidades, o planejamento se popularizou. O uso indiscriminado do termo impedia distinguir seu formato e ao tentar ser tudo o planejamento não era nada (LOASBY, 1973. Mintzberg (2004), entretanto, coloca que, de qualquer forma, o planejamento fixou um nicho viável para si mesmo, por meio de seus próprios erros e acertos. A necessidade então não é tanto criar um lugar para o planejamento, como organizar o que ele já ocupa.

Essa indefinição do planejamento, ou o ser tudo sem ser nada, pode estar refletida nas explicações encontradas e analisadas por Mintzberg (2004) sobre a questão relativa aos 
entendimentos dos significados de planejar, planejamento e estratégia, às vezes inconsistentes, às vezes avançando em outras áreas. Essas explicações podem ser classificadas como orientadas ao tempo, à decisão e à formalização.

Posteriormente, Mintzberg (2004) volta com definições sobre planejamento e faz crítica a sua elaboração mostrando como evitar armadilhas e falácias, principalmente, nas escolas do planejamento. Para o autor alguns conceitos citados por outros autores são importantes para entender planejamento como:

- Planejamento é pensar no futuro.

- Planejamento é controlar o futuro.

- Planejamento é tomada de decisão.

- Planejamento é tomada de decisão integrada.

- Planejamento é um procedimento formal para produzir um resultado articulado, na forma de um sistema integrado de decisões.

Porém Mintzberg (2004) argumenta que o planejamento está situado na extremidade formal do continuum do comportamento organizacional, ele deve ser visto não como tomada de decisão, não como formalização de estratégia e não como administração, ou como a maneira preferida de fazer qualquer dessas coisas, mas simplesmente como o esforço de formalizar parte delas, por meio da decomposição, articulação e racionalização.

A grande falácia para o autor está ligada ao fato que planejamento estratégico não é formação de estratégia, assim como análise não é síntese. A análise pode preceder e apoiar a síntese, definindo as partes que podem ser combinadas em todos. A análise pode seguir e elaborar a síntese, decompondo e formalizando suas conseqüências. No entanto para Mintzberg (2004) a análise não pode substituir a síntese. Nenhuma elaboração jamais fará com que os procedimentos formais possam prever descontinuidades, informar gerentes desligados de suas operações, criarem novas estratégias. Em última análise, para Mintzberg (2004) a expressão "planejamento estratégico" demonstrou ser uma contradição.

O fato de o termo planejamento estratégico ser contestado por Mintzberg (2004) não invalida o projeto em questão, pois o objetivo maior é entender como as organizações lidam com o 
desenvolvimento do planejamento estratégico e suas derivações nos vários modelos e contextos organizacionais, o próprio autor faz referências a estes tópicos no final da sua obra, porém este projeto pretende dar mais consistência e nacionalização ao contexto.

\subsection{Linhas de pensamento das escolas do planejamento estratégico}

O planejamento estratégico utilizado e desenvolvido nas empresas engloba uma série de conceitos e técnicas que devem ser mesclados para ficar em conformidade com suas estruturas internas e ambientais. Do início histórico do planejamento estratégico até os dias de hoje, várias linhas de pensamento foram seguidas, e muito bem retratadas por Mintzberg (2000 e 2004). Ele as classificou em 10 escolas de pensamento de acordo com o Quadro 3.

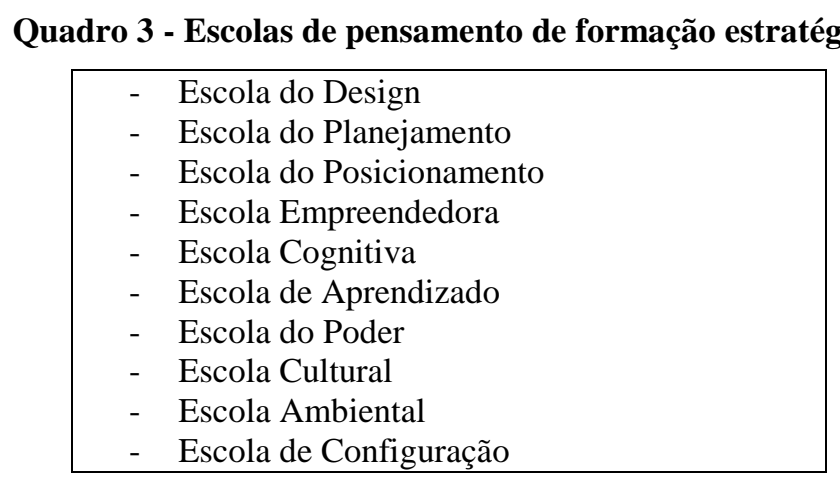

FONTE: Mintzberg (2000)

As três primeiras escolas de acordo com Mintzberg (2000) são de natureza prescritiva, mais preocupada em como as estratégias devem ser formuladas do que em como o são, as próximas seis denominadas descritivas, preocupam-se mais com a descrição de como as estratégias são, de fato, formuladas, do que com a prescrição e a última combina elementos de todas as outras. Busca a integração da formulação de estratégias, o conteúdo das mesmas, as estruturas organizacionais e seus contextos.

Ao analisar e classificar os aspectos relevantes de cada escola de pensamento, Mintzberg (2000) assumiu que isso facilitava sua interpretação, mas que ele poderia ser acusado de levar os conceitos das escolas excessivamente ao pé da letra. Embora seja mantida neste projeto a estrutura adotada por ele para as escolas de pensamento, é preciso considerar que ao longo dos anos muito se fez para evoluir nos modelos de cada escola, num aprendizado que permitiu avaliar melhor a aplicabilidade e os limites de cada conceito. 
Para se manter o direcionamento do trabalho serão descritas a seguir as características das escolas de natureza prescritivas, que serviram de base para o processo de desenvolvimento do planejamento estratégico.

\subsubsection{A Escola do Design}

A primeira escola de pensamento foi a do design, também denominada SWOT, termo tratado anteriormente, que serviu de referência para as duas seguintes, a do planejamento e do posicionamento. Suas idéias fundamentais estavam na obra de Selznick, "Leadership in Administration", publicado em 1957, mas sua popularidade veio com artigos da Harvard Business School e com o livro "Business Policy: Text and Cases" de Learned et al (1965). Mintzberg (2000) a denominou escola do design por ver seu processo concebendo a estratégia, desenhando-a de acordo com a Figura 1

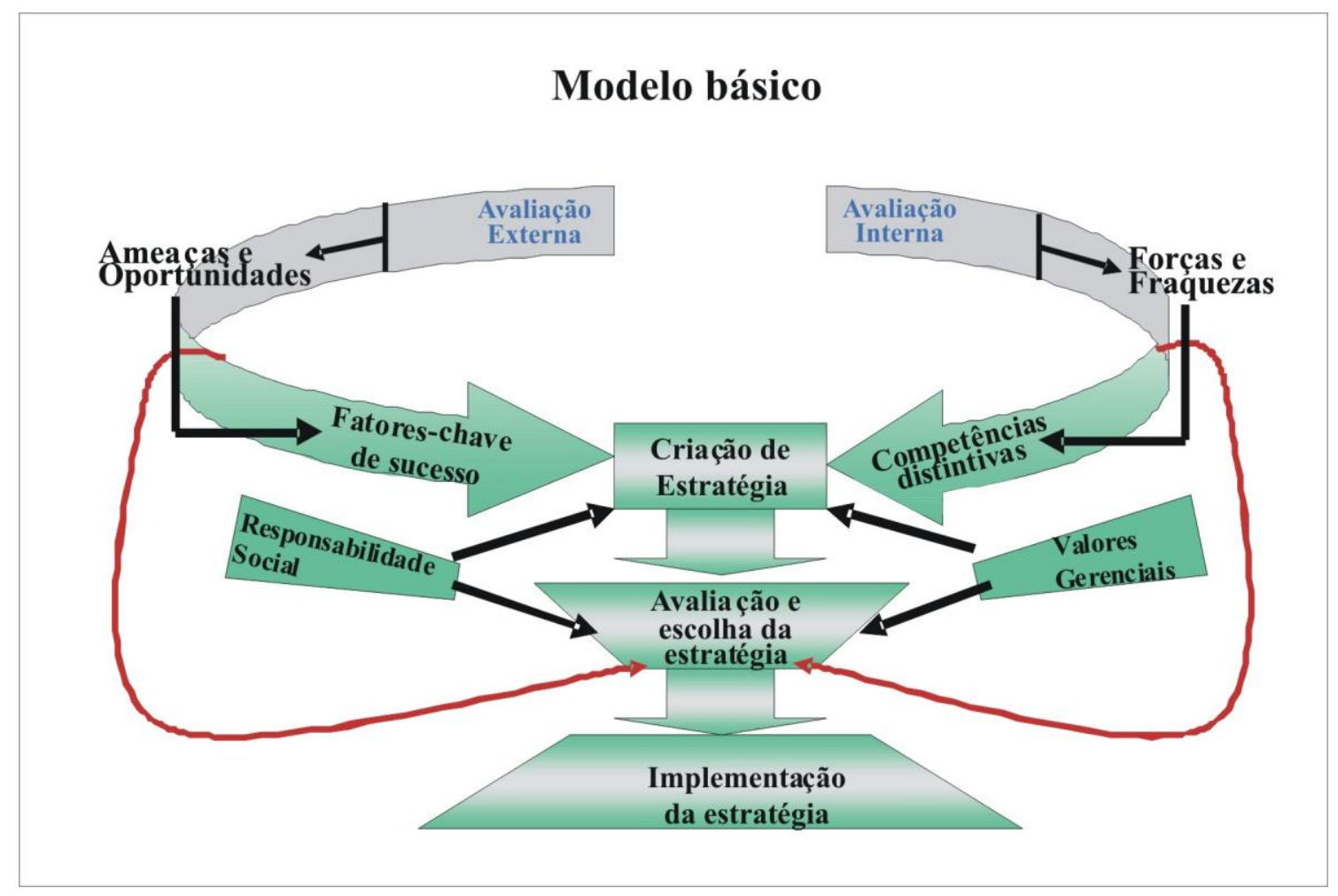

Figura 1 - A escola do Design FONTE: Mintzberg (2000)

A Escola do Design caracteriza-se pela busca da adequação entre a empresa e seu ambiente, mantendo a característica da visão de fora para dentro. Ela confronta as oportunidades e ameaças do ambiente externo, levando em considerarão os fatores-chave de sucesso do negócio, com as forças e fraquezas da empresa, chegando as suas competências distintivas. 
Dessa análise, pode-se buscar aproveitar as oportunidades por meio das forças internas, utilizando-se as competências existentes, ou adquirindo-as e evitar as ameaças, por meio de soluções para as fraquezas existentes. Conceitualmente, podem-se criar estratégias possíveis e selecionar as mais eficazes, respeitando-se os valores gerenciais e a responsabilidade social da empresa. De maneira bastante simples, o modelo divide o processo em duas fases: formulação e implementação.

O modelo se baseia em algumas premissas, extraídas por Mintzberg (2000) e Christensen et al (1982):

- A formação da estratégia é um processo de pensamento consciente e controlado, deliberado, cujo modelo deve ser simples e informal.

- A responsabilidade pelo processo deve ser do principal executivo.

- As estratégias devem ser únicas, as melhores resultam de um processo criativo e construídas sobre competências.

- A estratégia deve sair do processo de concepção. A formulação se encerra com o delineamento das estratégias possíveis e a escolha da mais eficaz, caracterizando um processo de decisão.

- As estratégias devem ser explícitas.

- A estrutura deve seguir a estratégia.

Essa escola assume uma postura ativa frente ao ambiente, interpretando os ambientes e agindo sobre eles, não apenas reagindo a eles. Ela ainda é a escola de pensamento mais influente, não apenas por ter sido a primeira, mas pela sua abrangência conceitual. Ela não só influenciou as demais, como tem uma estrutura que leva à consideração de aspectos abrangentes de uma elaboração estratégica, e ainda, adapta-se às várias formas e modelos analíticos mais recentes para cada uma de suas fases.

Com relação às estratégias geradas, as apropriadas devem ser consistentes em relação aos objetivos e políticas da empresa e de acordo com seus ambientes, manter ou levar as novas vantagens competitivas e serem viáveis com os recursos da empresa ou os de terceiros que ela possa utilizar produtivamente. 


\subsubsection{A Escola do Planejamento}

A Escola do Planejamento seguiu a do design e sua referência é o livro "Corporate Strategy", de Ansoff (2001). Sua diferença básica em relação à escola do design está na fixação de objetivos formais. Enquanto a escola do design oferecia uma estrutura conceitualmente livre, que abria espaços para a criatividade dentro dos limites de desenvolvimento do processo, a escola do planejamento formalizou o processo em fases seqüenciais fechadas e elaboradas, tornando-se mais instrumental e controladora.

Enquanto na escola do design o principal planejador era o principal executivo, na do planejamento ele passou a ser, muitas vezes, o aprovador de estratégias elaboradas por planejadores profissionais, agora mais importantes como planejadores ou consultores.

Aparentemente, a escola do design voltava-se mais ao conteúdo e a do planejamento à forma. A escola do planejamento pode ser interpretada como a escola do design, com seu modelo SWOT, separado em etapas bem divididas e analisadas tecnicamente. Mintzberg (2000) defende que, embora a denominação da escola seja planejamento, o seu objetivo era, pela extensão dos procedimentos, mais voltado ao controle com estratégias delineadas ao longo do processo conforme restrições impostas pelo modelo. Seus resultados eram objetivos, estratégias e programas reunidos em um único plano mestre.

A escola do planejamento separa o planejamento da ação, estratégias e programas, do controle de desempenho, objetivo e orçamentos. "Os objetivos dirigem a formulação de estratégias, as quais, por sua vez, evocam programas cujos resultados influenciam os orçamentos para fins de controle" (MINTZBERG, 2000, p. 49). A Escola do Planejamento baseia-se nas seguintes premissas:

- A formação da estratégia deve ser controlada e consciente e o processo formalizado e elaborado, decomposto em passos distintos, delineados por checklists e suportado por técnicas instrumentais.

- A responsabilidade pelo todo do processo recai em princípio sobre o executivo principal e a responsabilidade pela execução fica, na prática, com os planejadores.

- As estratégias saem acabadas do processo como posições gerais, para serem implementadas por meio de objetivos, orçamentos, programas e planos operacionais detalhados. 
As premissas mantêm aspectos da escola do design, mas abandonam seu caráter informal. Ao não abordar aspectos relevantes da criação da estratégia, deixa no ar a sensação de ser o modelo uma forma de trabalhar quantitativamente.

No âmbito da escola do planejamento, dois desenvolvimentos têm destaque: o planejamento por cenários e o controle estratégico.

A popularização do planejamento por cenários veio com os trabalhos desenvolvidos na Shell (GEUS, 1998).

O termo cenário não é de clareza absoluta. Rebouças (2001) menciona sete definições de cenários, de vários autores, concluindo que delas constam palavras-chave como situação futura idealizada, processos causais, decisão e ambientes alternativos.

Há vários métodos para analisar cenário e dezesseis deles podem ser encontrados em Rebouças (2001). Limita-se à base conceitual de que a montagem de cenários passa pelas análises do macroambiente: político-legal, econômico, demográfico, sócio-cultural, tecnológico e natural e a construção de diferentes perspectivas de futuro, o que requer abstração e dedicação para se poder criar o referencial para mudanças de postura organizacional.

A forma de análise não convencional ou o pensar no que aconteceria se os melhores sonhos ou os piores pesadelos se tornassem realidade, pode ajudar a aceitar a idéia de Prahalad e Hamel (1995) de que se deve diferenciar a competição de mercado da competição pelas oportunidades. Mesmo que não se adote o planejamento por cenários na magnitude do utilizado pela Shell, eles fazem parte da análise situacional no Processo de desenvolvimento do planejamento estratégico.

$\mathrm{Na}$ administração de grandes corporações, é grande a preocupação em garantir que suas empresas mantenham-se alinhadas com os caminhos estratégicos escolhidos pela corporação. Goold e Campbell (1987) consideram três estilos diferentes na criação das estratégias:

- Planejamento estratégico - há envolvimento da direção central nas decisões dos negócios individuais buscando preservar o todo.

- Controle financeiro - há envolvimento mínimo na definição estratégica, sob responsabilidade das unidades de negócios. 
- Controle estratégico - há combinação entre a autonomia das unidades de negócios e os interesses corporativos. As unidades de negócios desenvolvem as estratégias, que devem ser aprovadas pela direção central. Uma vez aprovadas, seus resultados são monitorados pela direção central. Poucas empresas têm um sistema realmente eficaz de controle estratégico, que leve ao questionamento das premissas que originaram as estratégias e não apenas às mudanças nos comportamento das pessoas. Como o importante para a empresa é o seu desempenho, e não o planejamento, o controle estratégico deve ir além dele, monitorando não apenas as estratégias deliberadas como também as emergentes.

\subsubsection{A escola do Posicionamento}

A escola do posicionamento foi muito influenciada por um momento econômico americano e enfatizou a importância da estratégia para os negócios ao mesmo tempo em que acrescentou substância analítica ao processo. Entretanto, ao focar na análise, limitou a liberdade instrumental das escolas anteriores, principalmente a do design. Mintzberg (2000) divide a escola em três grandes fases: a das máximas militares, a das consultorias e a dos modelos analíticos:

- Máximas militares, os destaques dessa fase são os escritos de Von Clausewitz (1966) e Tzu (1996), que ofereciam soluções para vários campos de batalha, disposições e tamanhos de tropas. Algumas dessas máximas são de fácil interpretação e adaptação aos negócios, mas outras requerem um grau maior de abstração. Uma publicação muito popular sobre estratégias de guerra nos negócios é Marketing Warfare, de Ries e Trout (1986), e um bom resumo dessas categorias de estratégias podem ser encontrados em Kotler e Keller (2006). Nesse resumo estão incluídas as estratégias de ataque; frontal, de flanco, de cerco, by pass e de guerrilha e defesa; de posição, de flanco, antecipada, de contra-ofensiva, móvel e de retração.

- A fase das consultorias foi favorecida pelo fato de o ambiente empresarial estar mais voltado à Economia e privilegiando aspectos relacionados ao desempenho. Foram desenvolvidos nesses ambientes vários modelos, já citados anteriormente como a matriz de crescimento e participação do Boston Consulting Group e a Matriz McKinsey-GE, ambas para análises de portfólio, e o Profit Impact of Market Strategies (PIMS) que relacionava, entre outros elementos, volumes e lucratividades. 
- A terceira fase da escola do posicionamento é a do seu maior desenvolvimento e nos remete aos anos de 1980. Seu grande expoente é Porter (1980). Essa fase trouxe modelos analíticos sólidos, e seus conceitos foram agrupados sob a denominação de Administração Estratégica (Mintzberg, 2000). Porter (1985) propunha estratégias genéricas que giravam em torno da competição por preços ou pela diferenciação da oferta, abrindo a possibilidade de se concentrar a ação em um grupo de consumidores ou no mercado amplo.

A partir destas colocações pode-se chegar a uma definição de planejamento estratégico relacionada à formulação de princípios e procedimentos que dizem respeito ao oferecimento de produtos ou serviços para o atendimento do mercado, levando-se em consideração os recursos disponíveis e as mudanças do ambiente. Cria-se a consciência das suas oportunidades, ameaças, seus pontos fortes e fracos para o cumprimento da sua missão, visando aproveitar as oportunidades e evitar os riscos.

As escolas prescritivas tiveram forte influência no desenvolvimento das etapas, passos e análises no Processo de desenvolvimento do PE, descrevê-las e entender suas evoluções são importantes para o desenvolvimento dos atributos que irão relacionar o processo aos modelos organizacionais estudados.

A seguir serão levantados às etapas, passos e análises para o processo de desenvolvimento do planejamento estratégico segundo autores nacionais e internacionais, e ao final pretendem-se compilar aspectos comuns para definição dos atributos da pesquisa.

\subsection{Planejamento estratégico para Fischmann e Almeida (1991), Almeida (1997 e 2003) e Rebouças (2003)}

Antes de abordar as etapas, passos e análises associadas ao planejamento estratégico é importante destacar que numa organização a administração se dá em três níveis:

- Estratégico: define a direção da organização adaptando-se ao meio ambiente e cabe a Diretoria ou Conselho de Administração.

- Administrativo: cuida do relacionamento e integração interna da organização e faz o elo entre a área administrativa e operacional.

- Operacional: cuidam das operações como compras, vendas, produção. 
Estes níveis podem distinguir três tipos de planejamento: estratégico, tático e operacional. De forma resumida o planejamento estratégico relaciona-se com objetivos de longo prazo e com estratégias e ações para alcançá-los que afetam a empresa como um todo, ou risco e amplitude maior.

O planejamento tático relaciona-se a objetivos de médio prazo com riscos e amplitude que afetam parte da empresa como um plano de marketing ou financeiro.

O planejamento operacional é o dia a dia, com riscos e amplitude muito menores como uma alteração no produto ou plano de cargos e salários.

As etapas, passos e análises do planejamento estratégico para Almeida (2003) seguem o modelo da Figura 2.

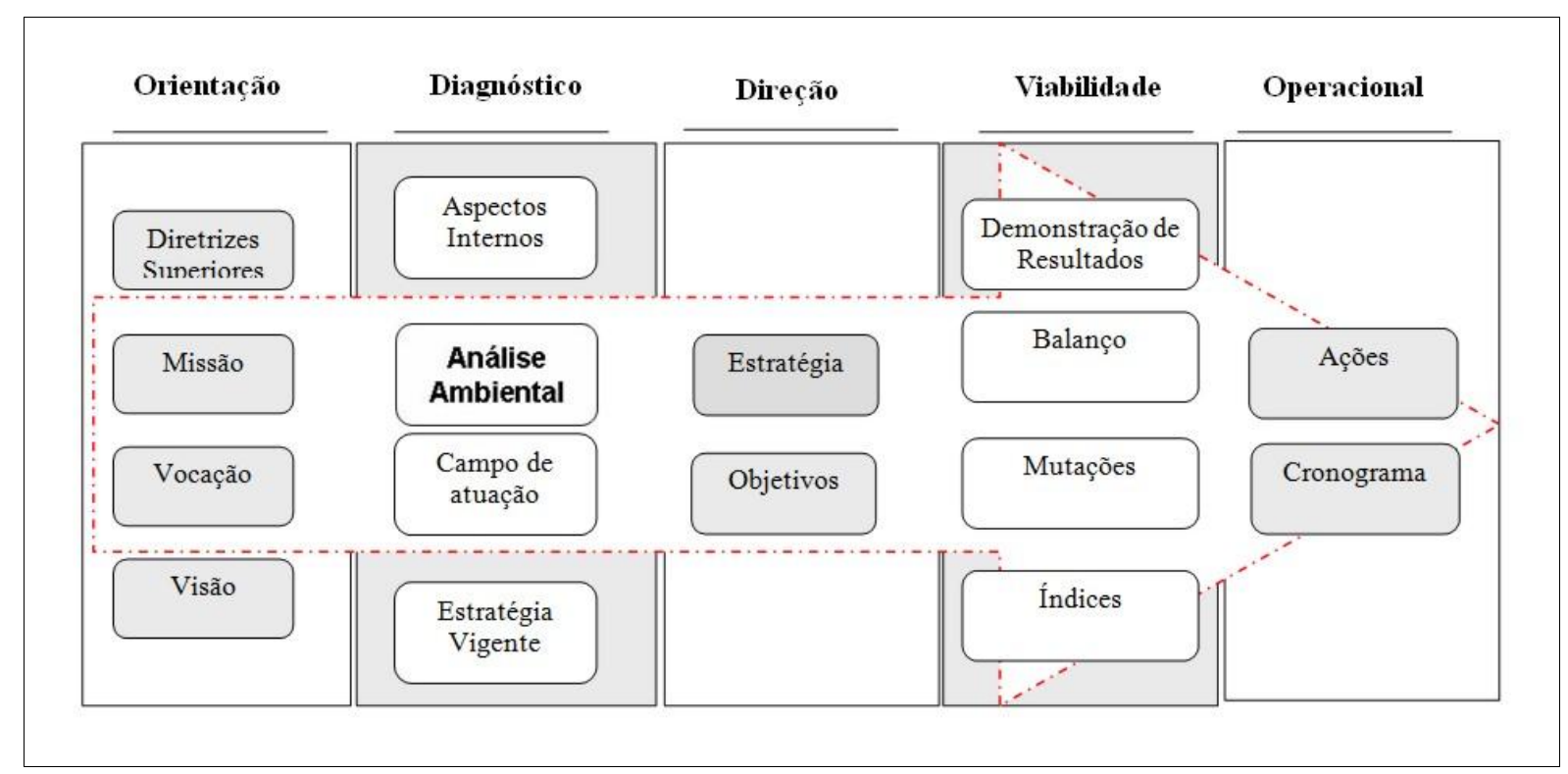

Figura 2 - Modelo para elaboração do planejamento segundo Almeida FONTE: Almeida (2003)

A orientação está voltada ao estabelecimento da missão, vocação e visão, ou a razão de ser da empresa, orienta a estratégia e não pode ser mudada em espaços de tempo muito curto, é mais usada nas grandes empresas e nas Unidades de Negócio de grandes corporações.

O diagnóstico segue a abordagem SWOT da Escola do Design e pode ter técnicas de aplicação diferente em diferentes organizações, o que se espera é que as análises sejam consistentes e confiáveis. 
Para Almeida (1997), tem-se como fator importante neste diagnóstico à análise do ambiente. É tudo aquilo que influencia o desempenho da entidade, pessoa ou organização, sem que ela pouco ou nada possa fazer para mudar esses fatores/variáveis, sendo a análise do ambiente uma etapa muito importante do planejamento estratégico.

A entidade busca a eficácia a partir das oportunidades e ameaças identificadas. Para se ter sucesso deve-se aproveitar as oportunidades e evitar as ameaças.

Para facilitar a análise do ambiente, Fischmann e Almeida (1991) utilizam o conceito de segmentação ambiental, de acordo com o Quadro 4.

\section{Quadro 4 - Segmento ambiental}

\begin{tabular}{|c|c|c|}
\hline Segmento Ambiental & Variáveis Ambientais & $\begin{array}{c}\text { Características } \\
\end{array}$ \\
\hline Macro ambiente clima & $\begin{array}{l}\text { Relações de poder (fatores políticos } \\
\text { que determinam o comportamento das } \\
\text { variáveis) tais como: restrição à } \\
\text { importação, incentivos fiscais }\end{array}$ & $\begin{array}{l}\text { A previsão do clima pode ser de } \\
\text { curtíssimo prazo ou uma tendência a } \\
\text { longo prazo }\end{array}$ \\
\hline Macro ambiente solo & $\begin{array}{l}\text { São compostos da população e suas } \\
\text { características, fornecendo a receita } \\
\text { necessária para manter e desenvolver a } \\
\text { empresa. Tais como: aumento da } \\
\text { população por região, por idade e sexo }\end{array}$ & $\begin{array}{l}\text { As transformações são lentas e } \\
\text { previsíveis }\end{array}$ \\
\hline Ambiente operacional & $\begin{array}{l}\text { Organizações e pessoas que sem } \\
\text { pertencer à empresa, relacionam-se } \\
\text { diretamente com suas atividades. Tais } \\
\text { como concorrentes, fornecedores e } \\
\text { clientes }\end{array}$ & $\begin{array}{l}\text { As previsões são feitas com um } \\
\text { conjunto de variáveis, pois estes são } \\
\text { interdependentes }\end{array}$ \\
\hline Ambiente interno & $\begin{array}{l}\text { É a parte humana e incontrolável das } \\
\text { pessoas que participam diretamente da } \\
\text { empresa. Tais como: valores e } \\
\text { aspirações. }\end{array}$ & $\begin{array}{l}\text { São os determinantes dos indivíduos e } \\
\text { grupos que orientam as suas ações }\end{array}$ \\
\hline
\end{tabular}

FONTE: Fischmann e Almeida (1991)

Para Fischmann e Almeida (1991), deve-se analisar apenas aquelas que tenham relevância para a empresa. Isso é feito relacionando o comportamento de uma variável ambiental em períodos de sucesso e de fracasso. Se o comportamento não se altera nesses períodos, deduzimos que o seu comportamento não é relevante para o desempenho da empresa.

Outro aspecto importante da análise de ambiente é o planejamento de cenários, citado na escola do Planejamento. Para Heijden (2005) o planejamento de cenários é particularmente recomendado para organizações que:

- Operam num ambiente com alto grau de incerteza e seus administradores têm pouca habilidade para lidar com previsões ou necessidades de ajustes. 
- Tem um histórico de surpresas que custou muito dinheiro.

- Tem dificuldades para perceber ou gerar novas oportunidades.

- São muito rotineiras e possuem pensamento estratégico pobre.

- Estão num ramo industrial que tem apresentado mudanças significativas.

- Estão à procura de uma linguagem comum.

- Tem fortes diferenças internas de opinião, muitas com mérito.

- Seus concorrentes usam planejamento de cenário.

A direção está relacionada ao tipo de estratégia que será adotada, o importante é que esteja condizente com as análises anteriores e busque sinergias comerciais, operacionais, de investimento ou administrativas. Os principais tipos de estratégia estão relacionados à integração vertical, integração horizontal, economia de contenção, desinvestimentos, liquidação do negócio, penetração de mercado, desenvolvimento de novos produtos ou novos mercados, diversificação, concentração, retração, inovação, enfim várias são as alternativas e a organização poderá escolher uma ou combinar vários tipos.

Os objetivos têm a função de verificar aquilo que foi projetado na direção, podem ser de longo, médio e curto prazo e a dimensão destes prazos está relacionada ao porte da organização e o ramo de atividades que ela se encontra. Grandes corporações podem trabalhar com objetivos superiores a cinco anos, pequenas empresas o aconselhável é trabalhar com prazos de no máximo três anos.

Eficácia é a palavra usada para indicar que a organização realiza seus objetivos. Quanto mais ela atinge seus objetivos mais ela demonstra sua eficácia, Certo et al (2005), especificam algumas características dos objetivos eficazes:

- Específicos, indicam exatamente o que deve ser realizado, por quem e dentro de que intervalo de tempo.

- Exigentes de esforços, ou seja, desafiadores e deve ser difícil o suficiente para que os funcionários tenham que se esforçar para alcançá-los.

- Atingíveis, todos os membros devem considerar os objetivos atingíveis. 
- Flexíveis, podem ser modificados se necessário.

- Mensuráveis, quantificado, que não gere dúvida.

- Consistente em longo prazo, de acordo com a missão organizacional e que suportem diversos cronogramas em suas etapas até serem atingidos.

A viabilidade está relacionada aos indicadores ou demonstrativos financeiros, como contribuição por produto ou Unidade de Negócio, lucros e perdas, balanço, fluxo financeiro e outros indicadores.

As ações e o cronograma estão relacionados à operacionalização do planejamento e de preferência devem conter os prazos, responsáveis e custos de cada ação assim como sua situação atual e pretendida. É importante que o plano possa ser divulgado para todas as pessoas de decisão da empresa e os detalhes deverão ser do conhecimento apenas dos responsáveis de cada área.

\subsection{Planejamento estratégico para Wright et al (2000), Thompson e Strickland (2000), Aaker (2001) e Kluyver e Pearce (2007)}

Para os autores, de acordo com a Figura 3, o planejamento estratégico deve ser elaborado em cinco etapas, análises dos ambientes externos e internos, formulação de estratégias, implementação de estratégias e controle estratégico.

Estas etapas são similares em todos os autores pesquisados, porém cabe um aprofundamento nos itens implementação da estratégia e controle estratégico. 


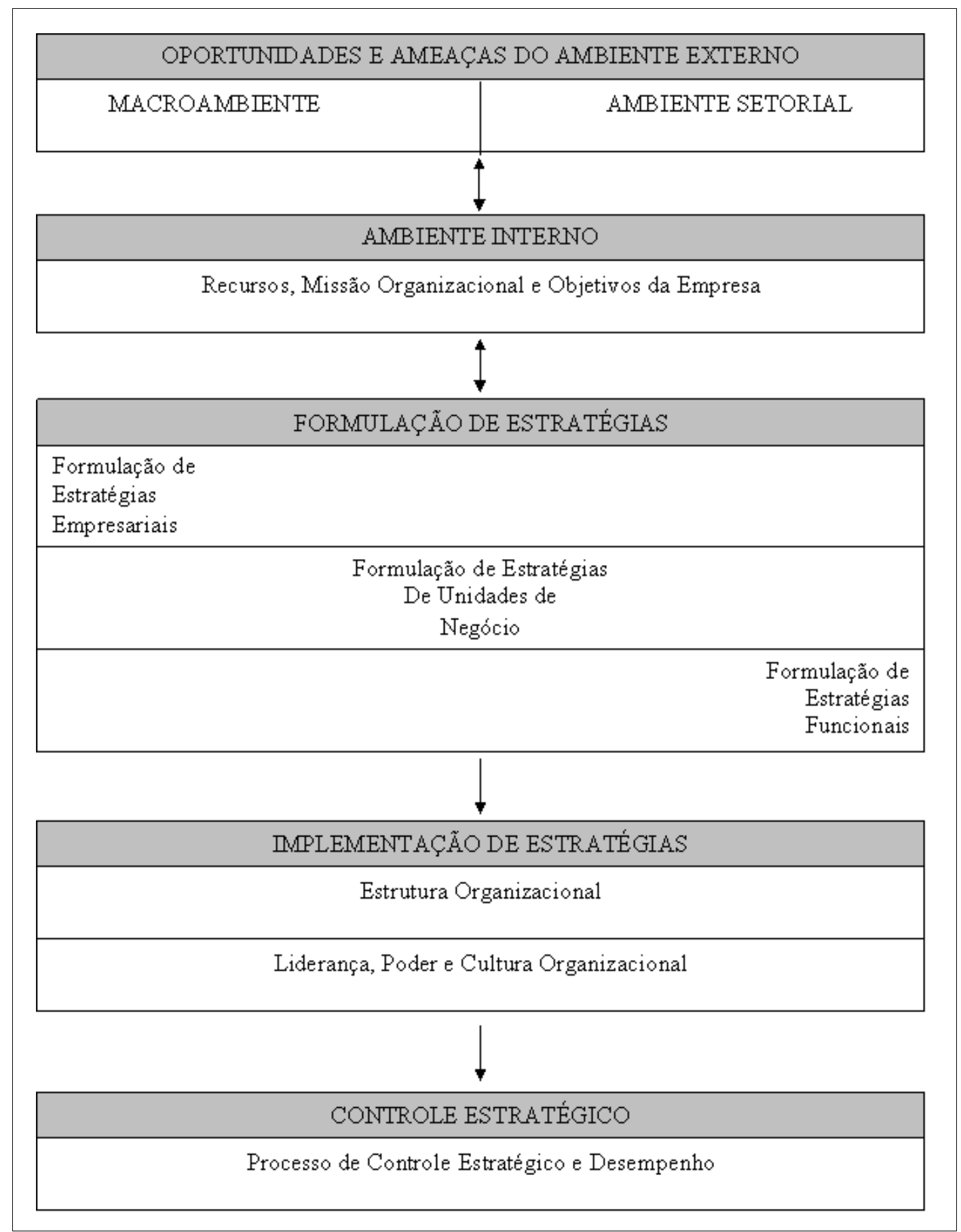

Figura 3 - Modelo adaptado para elaboração do planejamento estratégico

FONTE: Wright et al (2000), Thompson e Strickland (2000), Aaker (2001) e Kluyver e Pearce (2007)

$\mathrm{Na}$ implementação da estratégia deve-se verificar como a estrutura se apresenta. Para Chandler (1962) as organizações tendem a crescer em padrões um tanto previsíveis, inicialmente pelo volume, depois pela geografia, em seguida pela integração vertical e horizontal, finalmente pela diversificação de produtos, ou seja, os padrões de crescimento determinam sua forma estrutural. 
Vasconcellos e Hemsley (1997) colocam que a estrutura de uma organização é o resultado de um processo através do qual a autoridade é distribuída, um sistema de comunicação é delineado permitindo a realização de atividades e exercício da autoridade para se atingir os objetivos organizacionais.

Aaker (2001) escreve que a estrutura organizacional define linhas de autoridade e comunicação, e especifica o mecanismo pelos quais as tarefas e os programas organizacionais são cumpridos. A estruturação de acordo com Araújo (2001) é uma forma sistematizada de agrupar atividades em frações organizacionais definidas seguindo um dado critério, visando à melhor adequação da estrutura organizacional e sua dinâmica de ação.

O termo departamentalização muitas vezes é utilizado para representar a estrutura de uma organização, deve-se tomar o cuidado para não associar departamentalização com criar departamentos e sim criar unidades, frações organizacionais. Essas unidades podem ser divisões, gerências, assessorias, conselhos, células e departamentos (ARAÚJO, 2001).

Para se entender melhor as organizações devem-se estudar os critérios de departamentalização ou estruturação, que são grupos de indivíduos em unidades específicas.

Vasconcellos e Hemsley (1997) e Certo et al (2005) denominam as estruturas como:

- Funcional: base no conhecimento necessário para a realização de determinadas atividades.

- Geográfica: opera em áreas geográficas diferentes e existe necessidade de tratá-las de forma diferente.

- Processo: normalmente utilizado no setor de produção, por exemplo, fundição, usinagem, montagem, etc.

- Por cliente: quando a organização trabalha com diferentes tipos de clientes exigindo tratamento especializado.

- Por produto ou serviços: quando os produtos são muito diversificados.

- Por período, unidades cuja única diferença é o período no qual suas equipes trabalham. 
- Pela amplitude de controle: leva-se em consideração o número máximo de pessoas que o chefe pode coordenar eficientemente.

- Por projetos ou matricial: a organização se adapta ao projeto com equipes multidisciplinares.

Não há regras rígidas que determinem qual estrutura organizacional é melhor para uma empresa em particular, cada abordagem estrutural tem vantagens e desvantagens que os administradores devem considerar ao projetar uma estrutura organizacional ou ao mudar de uma estrutura para outra.

Outros aspectos importantes para se compreender a estrutura organizacional, de acordo com Vasconcellos e Hemsley (1997) estão relacionados à:

- As áreas de apoio podem ser centralizadas ou descentralizadas.

- Decisões centralizadas na alta administração podem causar lentidão e decisões descentralizadas podem ocasionar falta de coordenação e controle.

- O sistema de comunicação está relacionado à definição dos canais de comunicação, ela pode ser:

- vertical, do chefe para o subordinado.

- horizontal, quando dois elementos de unidades diferentes se comunicam diretamente.

- diagonal, quando os elementos estão em unidades e níveis hierárquicos diferentes.

- O grau de formalização também é importante, deve-se chegar a níveis que não comprometam a agilidade e não levem ao conflito ou ineficiência. Os mais utilizados são os organogramas e descrição de atribuições.

- A operação real de uma organização acontece através de sua estrutura formal e informal simultaneamente.

- A unidade de comando está relacionada á hierarquização da organização, priorizando, desde a escola clássica que cada funcionário tenha um chefe. 
De acordo com Keats e O’Neil (2001), a estratégia tem muito mais influência na estrutura do que o inverso, porém para Zajac e Yin (2004), a estratégia e estrutura têm uma relação de reciprocidade que evidencia a interligação entre a formulação da estratégia e sua implementação. Ou seja, a estrutura resulta da seleção da estratégia da empresa ou a segue. Uma vez definida a estrutura pode influenciar as ações estratégicas atuais, assim com a escolha de futuras estratégias.

Diante desta relação entre estratégia e estrutura, fica claro que a decisão deve ser tomadas levando-se em consideração a adequação da estrutura a estratégia de forma a manter a estabilidade necessária para a utilização das vantagens competitivas atuais, bem como a flexibilidade que é exigida para o desenvolvimento de futuras vantagens.

Liderança, poder e cultura organizacional serão tratados nos tópicos seguintes relacionados aos modelos organizacionais.

Quanto ao controle estratégico e desempenho de forma direta ou indireta, implícita ou explícita, as organizações utilizam alguma forma de avaliação, variando com a complexidade de cada empresa, suas ambiências, dinamismo setorial e volume de recursos dos quais disponham.

Do início do período industrial, quando a preocupação com os resultados operacionais era suficiente, aos dias de hoje, quando não basta controlar os resultados puramente internos, mas também aqueles que impactam a sociedade, vários sistemas foram desenvolvidos. Da eficiência na produção, de Taylor (1995), passando pela Management by Objectives (MBO) de Drucker (1986) e outros ao Triple Bottom Line da sustentabilidade do modelo Sigma, o nível de sofisticação foi aumentado.

À medida que os processos de internacionalização de empresas se acentuam, torna-se mais relevante o desenvolvimento de modelos que permitam avaliar o desempenho de empresas no seu conjunto de atividades, o que por sua vez traz modelos adequados a empresas que mesmo operando localmente buscam padrões internacionais de gestão.

$\mathrm{Na}$ administração de grandes corporações, por exemplo, é grande a preocupação em garantir que suas empresas mantenham-se alinhadas com os caminhos estratégicos escolhidos pela corporação. Embora as unidades estratégicas de negócios desenvolvam as estratégias, estas devem ser aprovadas pela direção central, que irá monitorar seus resultados. 
Esse modelo pode também ser utilizado por corporações locais e orientar os diferentes níveis de participação de cada nível hierárquico. Assim, entender e controlar desempenho, de forma integrada, não deve ser privilégio das grandes corporações. Utilizando sistemas mais simples, e compatíveis com os recursos disponíveis, lembrando da máxima que o controle não deveria ser mais caro que o que é controlado, empresas de qualquer porte podem adotar mecanismos que lhes permitam responder se a empresa está ou não no caminho certo, conforme idealizado pelos seus proprietários ou executivos.

Um aspecto relevante no desenho de modelos de controle de desempenho integrado é sua conexão com a estratégia, bem desenvolvido por Kaplan e Norton (1997).

Estes trabalhos mostram um método simples de utilização dos indicadores de desempenho, que posteriormente deu origem ao livro Balanced Scorecard: a estratégia em ação em que Kaplan e Norton (1997) detalharam o conceito e apresentaram o Balance Score Card (BSC) como um novo sistema de gestão estratégica.

Uma vez definida a estratégia, freqüentemente seu controle sai das mãos dos estrategistas, ficando a implantação a cargo de áreas funcionais ou de projetos, sob risco de se perder o controle da execução e adequação às expectativas que originaram as estratégias. Vários modelos de controle não se restringem à definição de um conjunto de indicadores, mas partem para a construção de uma lógica que permita às organizações organizarem e ampliarem sua competitividade, controlando resultados e buscando orientar novas medidas. Os chamados “indicadores de sucesso" do passado ganham corpo e converte-se em sistema de gerenciamento mais complexo.

Um quadro resumo na síntese da revisão de literatura mostra todos os assuntos tratados até este tópico e sua importância para relacioná-los ao processo de desenvolvimento do planejamento estratégico com os modelos organizacionais escolhidos.

A seguir serão abordados o tema organizações e seus modelos, desde sua evolução até as características e particularidades que definirão os atributos para classificar cada modelo e posterior identificação e análise, relacionando-os com o processo de desenvolvimento do planejamento estratégico. 


\subsection{Histórico das organizações}

A história da sociedade humana está ligada à história das organizações, que por sua vez não é uma invenção moderna. As pirâmides foram construídas pelos faraós, os imperadores da China também construíram grandes sistemas de irrigação e os primeiros Papas criaram uma igreja universal a fim de servir a uma religião, tudo isto milhares de anos atrás, com fortes características organizacionais, ou seja, uma organização é um sistema administrativo projetado e operado para atingir um determinado conjunto de objetivos.

Para Mooney (1947) e Schein (1972), as organizações baseiam-se na coordenação racional das atividades de certo número de pessoas, que desejam alcançar um objetivo comum e explícito, mediante a divisão das funções e do trabalho e por meio da hierarquização da autoridade e responsabilidade.

Torna-se difícil imaginar a sociedade atual sem a presença de organizações. Nascemos nelas e, usualmente, morremos nelas. O espaço entre estes dois termos é preenchido por elas. São tão inevitáveis quanto à morte e os impostos (HALL, 1984).

\subsubsection{As relações dos grupos sociais como organizações}

Maximiano (2007) divide os grupos sociais em primários e secundários. Nos grupos sociais primários predominam as relações pessoais, pois se tratam de famílias, grupos de amigos ou certos grupos sociais de caráter informal, já nos secundários prevalecem à formalização com normas rígidas e explicitas. Tanto para os grupos sociais primários como para os secundários, devem-se estabelecer objetivos, gerenciar recursos e dividir os trabalhos e processos de transformação. Ou muitas vezes para gerenciar sistemas complexos ou com algum grau de dificuldade os grupos sociais primários comportam-se como organizações, porém não são organizações formais permanentes.

Lacombe e Heilborn (2003) entendem que organizações informais não têm interesse prático no estudo da administração e que uma característica importante da organização que a distingue de outros tipos de sistemas sociais é a prioridade para a consecução de uma meta específica. Segundo esse critério, os grupos informais não são organizações nesse sentido técnico. Pode-se dizer, portanto, que sem objetivo nenhuma organização teria razão de existir e, em consequiência, todas as organizações realizam objetivos. 
Essa é a diferença: todos os grupos sociais têm os elementos que definem as organizações. Algumas são organizações formais, regidas por regulamentos, enquanto outros são grupos sociais primários ou informais, regidos por relações pessoais.

Dentro das organizações formais, de acordo com Lacombe e Heilborn (2003), surgem grupos espontâneos de pessoas que têm afinidades, interesses ou conhecimentos comuns. Estas relações pessoais funcionam como mecanismos de comunicação e podem afetar as decisões, favorecendo ou prejudicando a organização formal.

Estes conceitos são importantes para se entender como a elaboração de objetivos e, por sua vez, outras etapas no processo do planejamento estratégico são desenvolvidas, aceitas e praticadas dentro dos grupos informais e sua formalização na organização.

\subsubsection{Organizações formais e a burocracia}

A formalização das organizações ou o fato de serem regidas por regulamentos caracterizam-nas como burocracias. O trabalho que mais influenciou o estudo da burocracia foi o de Weber (1982 e 2001). Para o autor, a burocracia deveria ser um agrupamento social em que se rege o princípio da competência definida mediante regras impessoais, normas, regulamentos; da documentação; da hierarquia funcional; da permanência obrigatória do servidor durante determinado período; e da subordinação do exercício dos cargos às normas abstratas. O sentido pejorativo de burocracia associado à inflexibilidade, desperdício, complicação, demora ou algo pernicioso não deve ser associado exclusivamente aos estudos de Weber (1999). Qualquer organização média ou grande deve ter alguma forma de burocracia e o que deve ser julgado é em que grau ela deve ser admitida e sua maior ou menor eficiência. 


\subsection{Linhas de pensamento nos estudos das organizações}

Os trabalhos de Weber (1982, 1999 e 2001) são tão importantes que influenciaram praticamente todos os autores que retomaram o assunto. O Quadro 5 resume as principais contribuições ao estudo das organizações e sua evolução.

Quadro 5 - Modelos ou tipologias das organizações

\begin{tabular}{|l|l|}
\hline \multicolumn{1}{|c|}{ Autores } & \multicolumn{1}{c|}{ Principais Idéias } \\
\hline Weber (1982, 1999 e 2001) & Tipo ideal de burocracia \\
Mooney (1947) & Organizações tipo linear, funcional e linha-staff \\
Burns e Stalker (1961) & Modelo mecanicista e orgânico \\
Etzioni (1974 e 1976) & Tipos de poder \\
Mintzberg (1979 e 2006) & Configurações das organizações \\
Morgan (1996) & Imagens das organizações \\
\hline
\end{tabular}

FONTE: Adaptado de Maximiano (2007)

Diante dos vários estudos sobre modelos ou tipologias das organizações, optou-se no projeto pela base desenvolvida por Mooney (1947), Burns e Stalker (1961), Mintzberg (1979 e 2006) e Morgan (1996), porém, faz-se necessário a introdução de outros autores para reforço do referencial teórico, já que fica clara a coincidência entre eles e sua evolução no contexto das organizações, que serão melhores explicitados nos subtítulos à frente. Não será realizada uma análise das relações entre autores, mas o reforço para elaboração dos atributos que serão testados nas relações com o Processo de desenvolvimento do planejamento estratégico.

Para Mooney (1947) as organizações podem ser do tipo linear, funcional e linha-staff, suas características são:

\subsubsection{As organizações segundo Mooney (1947)}

a) Organização linear

A organização linear constitui a forma estrutural mais simples e antiga, pois tem sua origem na organização dos antigos exércitos e na organização eclesiástica dos tempos medievais. As formas mais antigas de organização possuem em comum o princípio da autoridade linear, também chamado princípio escalar que estabelece a hierarquia da autoridade. $O$ nome organização linear significa que existem linhas diretas e únicas de autoridade e responsabilidade entre superiores e subordinados. Daí seu formato piramidal. Cada gerente recebe e transmite tudo o que se passa na sua área de competência, pois as linhas de 
comunicação são rigidamente estabelecidas. É uma forma típica de pequenas empresas ou estágios iniciais das organizações. As vantagens da organização linear são:

- Estrutura simples e de fácil compreensão.

- Clara delimitação das responsabilidades dos órgãos e uma notável precisão de jurisdição.

- Facilidade de implementação.

- Estabilidade.

- Tipo de organização indicado para pequenas empresas.

Desvantagens da organização linear segundo Mooney (1947):

- Estabilidade e constância das relações formais.

- Autoridade linear baseada no comando único.

- A organização linear exagera a função de comando e chefia.

- A unidade de comando torna o chefe um gerente que não pode se especializar em nada.

- À medida que a empresa cresce, a empresa linear provoca congestionamento nas linhas de comunicação.

- As comunicações por serem lineares tornam-se demoradas.

b) Organização funcional

A organização funcional é o tipo de estrutura organizacional que aplica o princípio funcional ou princípio da especialização das funções. O princípio funcional separa, distingue e especializa, é o germe do staff. Com a organização funcional, o mestre de produção tornou-se um especialista em assuntos de produção, deixando de ser procurado pelos operários para cuidar de problemas. Vantagens da organização funcional:

- Proporciona o máximo de especialização nos diversos órgãos ou cargos da organização. 
- Permite a melhor supervisão técnica possível, com a especialização em todos os níveis.

- Desenvolve comunicação direta sem intermediação.

- Separa as funções de planejamento e de controle das funções de execução.

Desvantagens da organização funcional:

- Diluição e conseqüente perda de autoridade e de comando.

- Subordinação múltipla.

- Tendência de concorrência entre os especialistas.

- Tendência à tensão e conflito dentro da organização.

c) Organização linha-Staff

O tipo de organização linha-staff é o resultado da combinação dos tipos de organização linear e funcional, buscando incrementar as vantagens desses dois tipos de organização e reduzir suas desvantagens. Jucius e Shlender (1972) as denominam organização hierárquicoconsultivo. As características dos dois tipos de organização proporcionam um tipo de organização mais completa e complexa. Na organização linha-staff segundo Mooney (1947), coexiste órgãos de linha e de assessoria mantendo relações entre si. Os órgãos de linha caracterizam-se pela autoridade linear e pelo princípio escalar e os órgãos de staff prestam assessoria e serviços especializados. Vantagens da organização linha-staff:

- Assegura assessoria especializada e inovadora mantendo o princípio de autoridade única.

- Atividade conjunta e coordenada dos órgãos de linha e órgãos de satff.

Desvantagens da organização linha-staff:

- Existência de conflitos entre órgãos de linha e de staff.

- Dificuldade na obtenção e manutenção do equilíbrio entre linha e staff.

A organização do tipo linha-staff tornou-se o formato estrutural típico das empresas no mundo todo e, ainda hoje, prevalece na maioria das organizações. As comissões utilizadas 
como ferramenta provisória para evitar a constante alteração de estrutura organizacional e mantê-la estável é ainda utilizada. Contudo, na atualidade, as comissões estão sendo substituídas por um conceito mais dinâmico e moderno, as equipes. As equipes multifuncionais ou multidisciplinares, autônomas ou semi-autônomas são utilizadas no mundo todo para proporcionar flexibilidade e agilidade às organizações.

No trabalho de Mooney (1947) já se percebe as similaridades entre: organização linear com a empreendedora, funcional com a organização tipo máquina e linha-staff com a inovadora ou adhocrática, modelos que serão abordados a seguir.

\subsubsection{Modelos alternativos de organização de Burns e Stalker (1961)}

Ao estudar empresas na Escócia, Burns e Stalker (1961) identificaram empresas que estavam em declínio por pertencer a ramos industriais tradicionais e para ingressar no ramo de alta tecnologia passaram por dificuldades que levaram a criação de dois tipos de organização:

- Tipo mecanicista: muito parecido com a burocracia de Weber (1999) este tipo de organização é adequado a condições ambientais relativamente estáveis. As tarefas são especializadas e precisas. A hierarquia de controle é bem definida. A responsabilidade pela coordenação, assim como a visão de conjunto, pertencem exclusivamente à alta administração. A comunicação vertical é enfatizada. Organizações desse tipo valorizam a lealdade e a obediência aos superiores.

- Tipo orgânico: adaptada a condições instáveis e a ambientes com os quais a organização não tem familiaridade. Ambientes assim oferecem problemas complexos que não podem ser resolvidos por pessoas com especialidades tradicionais. Por isso, nos sistemas orgânicos, há contínua redefinição de tarefas. Ninguém é especialista em nada, ou todos são especialistas em tudo. A natureza cooperativa do conhecimento é enfatizada, não a especialização. Prefere-se a interação e a comunicação de natureza informativa, em lugar de ordens, o que cria alto nível de comprometimento com as metas da organização. Os organogramas são de pouca utilidade para descrever as tarefas das organizações do tipo orgânico. Muitas vezes, elas não têm organogramas.

No estudo os autores colocam uma dúvida quanto ao fato de organizações mecanicistas tornarem-se orgânicas. 
Organizações mecanicistas têm fortes tendências à formação de feudos, os compromissos são para o grupo mais próximo ou à própria carreira. Novas funções podem criar conflitos e estas organizações muitas vezes reagem à mudança.

O termo mecanicista permanece nos estudos dos autores a seguir, porém, a denominação orgânica passa por algumas transformações e adaptações ao nome.

\subsubsection{Tipologias de poder nas organizações segundo Etzioni (1974 e 1976)}

Etzioni (1974 e 1976) estabelece um estudo comparativo de organizações levando em consideração os padrões de consentimento. O consentimento distingue as organizações de outras coletividades, porque requerem mais consentimento do que as outras e está relacionado de maneira sistemática a muitas outras variáveis organizacionais.

Segundo Etzioni (1974 e 1976), há três tipos ou categorias de organizações: coercitivas, utilitárias e normativas, e também as estruturas dualísticas ou combinações entre elas: normativas-coercitivas, utilitárias-normativas e utilitárias-coercitivas. Cada tipo de organização é definido pelo tipo de poder exercido sobre as pessoas. Cada tipo de poder dá origem a um tipo de obediência.

A obediência é uma relação em que uma pessoa comporta-se de acordo com a orientação que é dada por outra e apóia-se no poder desta segunda pessoa. O tipo de poder determina o tipo de obediência, que define a natureza da organização.

\section{$\underline{\text { Organizações Coercitivas }}$}

Nas organizações coercitivas, a coerção ou força física é o principal meio de controle sobre os participantes operacionais, que não detêm o poder, chamados por Etzioni (1974) de participantes de nível mais baixo. A tarefa principal é deixar as pessoas do lado de dentro, impedindo-as de sair, se as restrições fossem suspensas e a coerção deixasse de ser usada, ninguém permaneceria na organização. Nas organizações coercitivas, as tarefas são realizadas por meio do uso real ou pela ameaça do uso de força.

Campos de concentração, prisões, instituições correcionais e hospitais penitenciários são os principais exemplos de organizações desse tipo de organização, no Brasil ainda se têm madeireiras ou fazendas principalmente nas regiões do Pará com esta configuração. 


\section{Organizações Utilitárias}

A remuneração é o principal meio de controle das organizações utilitárias. Nessas organizações, o envolvimento calculista caracteriza a orientação da grande maioria dos participantes operacionais e mesmo dos membros das elites. Normalmente, as empresas de negócios são organizações utilitárias. Porém, algumas delas podem ter estruturas normativas, quando os participantes de nível mais baixo são profissionais de nível superior, como consultores, advogados, pesquisadores ou médicos. Para empregados de fábrica, de forma geral, a remuneração é o principal meio de controle. No entanto, no conjunto, a remuneração pesa mais, segundo Etzioni (1974). Além da remuneração, as organizações utilitárias recorrem a recompensas como promoções, benefícios e incentivos para obter o comportamento esperado.

\section{$\underline{\text { Organizações Normativas }}$}

Organizações religiosas, organizações políticas de forte programa ideológico, hospitais gerais, universidades e organizações de voluntários, de forma geral, dependem muito mais do comprometimento de seus participantes operacionais do que de recompensas. Usar qualquer tipo de força está fora de cogitação e, em muitas delas, não há sequer necessidade de remunerar os participantes, que trabalham espontaneamente, sem esperar outra recompensa que não seja a própria participação ou a contribuição para realizar a missão. Estas são as organizações em que o poder normativo é o principal meio de controle dos participantes operacionais, os quais apresentam alto nível de comprometimento.

Nas organizações normativas, os participantes internalizam, orientações aceitas como válidas. Liderança, rituais, manipulação de símbolos sociais e de prestigio estão entre as técnicas de controle mais importantes nas organizações normativas. Apesar de ter sido enfatizada no passado, a coerção desempenha papel secundário.

\section{Estrutura Combinada de Obediência na Tipologia de Poder}

Etzioni (1974) identifica as organizações que utilizam combinação de dois tipos de poder: são as organizações com estrutura dupla de obediência: combinação de poder normativo e coercitivo em organizações de combate. Combinação de poder normativo e utilitário em alguns sindicatos. Combinação de poder utilitário e coercitivo em alguma indústria antiga, alguma fazenda ou trabalhadores de alguns navios. 
O poder como visto anteriormente tem influência na implantação da estratégia e um passo importante no Processo de desenvolvimento do planejamento estratégico.

\subsubsection{Novos modelos das organizações segundo Mintzberg (1979 e 2006)}

Nesta parte do referencial teórico, em primeiro lugar, são examinadas as imagens, que procuram classificar as organizações em certas categorias ou representá-las por meio de metáforas, Mintzberg (1979 e 2006) e Morgan (1996) ofereceram as principais contribuições para o desenvolvimento dessas idéias.

As idealizações de Weber (1999) são expandidas ou em alguns casos mantidas no desenvolvimento desses novos modelos organizacionais, que se dá de meados do século XX até a transição para o século XXI. Para Mintzberg (1979 e 2006), há sete tipos ou configurações de organizações. A estrutura da organização ou suas partes mais importantes serão caracterizadas por cada tipo e dependem de algumas condições. Percebe-se uma combinação de idealizações de Weber (1999) e Etzioni (1976). Cabe ao gestor compreender a configuração de sua organização para melhor ajustar suas estratégias, estruturas, mecanismos de avaliação e outros processos, porém muitas vezes esta configuração pode apresentar modelos híbridos ajustados ao mercado ou indústria que a organização pertence.

\section{Organização Empreendedora}

A organização empreendedora é o tipo mais simples de organização, fortemente centralizada na figura do executivo principal ou de um empreendedor que a fundou e a dirige. O exemplo mais comum são as empresas familiares.

Algumas características são importantes para se caracterizar uma empresa empreendedora: o poder tende a se voltar para o executivo principal, a estrutura é simples ou em alguns casos sem estrutura.

Mintzberg (1979 e 2006) identificou formas primárias de estrutura organizacional, que serão abordadas de acordo com o Modelo estudado e as associou aos fatores mais importantes para defini-las. Estes fatores estão relacionados às características do ambiente que a organização está inserida, qual a parte mais importante da organização e a coordenação do esforço para a realização de determinada ação em busca de um objetivo, como a seguir: 
- Fatores ambientais: Apresenta dificuldade na variabilidade do meio ambiente que muda continuamente tanto naquilo que é ou não vendável quanto em quantidades. O pequeno volume que necessitam impede pressionar fornecedores para concessão de facilidades. A vantagem é a versatilidade pelas reduzidas dimensões, permitindo que os proprietários mudem de ramo com facilidade.

- Parte-chave: está na cúpula administrativa gerenciada pelos proprietários.

- Coordenação: supervisão direta dos trabalhadores pelos proprietários. É o ponto fraco que necessitam serem analisados em três aspectos: personalidade, cultura e habilidades e conhecimentos.

A tomada de decisão é flexível com uma alta concentração de poder permitindo rápida reação. O controle pelo líder é rígido, mas com flexibilidade administrativa.

O conhecimento íntimo e detalhado do negócio faz com que o empreendedor se torne o arquiteto da estratégia e esse tipo de conhecimento pode ser eficiente quando concentrado em uma pessoa que está no comando e que retém um forte comprometimento de longo prazo para com a organização.

Porém o fato de na maioria das vezes a estratégia não estar formalizada e detalhada pode gerar direcionamentos duvidosos ou não direcionamento.

Muitas organizações passam por esse estágio estrutural em seus primeiros anos. Algumas que permanecem pequenas ou médias preservam esse modelo. Existe uma semelhança com o modelo orgânico pela sua flexibilidade e agilidade.

\section{Organização tipo Máquina}

O que caracteriza a organização tipo máquina são as ações repetitivas e muitas operações em rotina. Como resultados têm-se processos altamente padronizados e estruturas harmoniosas funcionando como máquinas integradas.

O foco está na essência operacional com fluxo de trabalho racionalizado. Prevalece a tecnoestrutura com níveis hierárquicos bem definidos e baixo poder de decisão por parte da maioria dos funcionários. Os gerentes têm um papel importante quando os conflitos aparecem, porque os problemas não podem ser resolvidos informalmente. 
Regras e regulamentos estão por todo o sistema. A ênfase na padronização se estende bem além da essência operacional e com ela segue-se à influência dos analistas. Como analistas podem-se considerar o trabalho de engenheiros de qualidade, programadores, contadores, coordenadores de operação e muito outros.

A estrutura é altamente funcional e existe uma grande obsessão pelo controle. A alta gerencia é a única com conhecimento mais generalista com perspectiva para enxergar todas as funções. Organizações maduras e que atuam em ambientes que lhe permitam um grande volume de trabalho operacional são normalmente denominadas organizações tipo máquina. Como a ação da empresa foi muito forte para dominar determinados mercados, o ambiente para ela pode ser considerado mais estável, conforme os fatores:

- Fatores ambientais: o ambiente necessita ser simples permitindo a divisão do trabalho em micro tarefa exigente de pouca habilidade. Ex. linhas de montagem. A base do planejamento está no núcleo operacional.

- Parte-chave: necessitam de especialistas com capacidade de especificar o que fazer, o quando e o como do núcleo operacional, com o fim de obter a eficiência. Tecnoestrutura é o mais importante componente, sendo que a concretização das atividades da empresa são as normas e processos padronizados.

- Coordenação: passa a ser o próprio processo de trabalho padronizado, ficando o supervisor com a função de atuar somente nos casos de exceção.

A organização tipo máquina tem forte embasamento no modelo burocrático de Weber (1999), a palavra máquina é encontrada na obra do autor e está associada a uma organização precisa, confiável e fácil de controlar, prima pela eficiência pelo menos enquanto restrita a tarefa que lhe foi conferida.

A estratégia numa organização tipo máquina, normalmente, parte da alta administração ou o topo da hierarquia, que tem a perspectiva mais ampla e o poder mais concentrado.

Como exemplos de organizações tipo máquina têm-se as grandes empresas industriais, usinas siderúrgicas, fabricantes de automóveis ou aviões, e mesmo pequenas indústrias podem optar por este tipo de estrutura. 
Uma abordagem interessante é que máquinas são instrumentos especializados, projetados para a eficiência e não para a adaptação, solução de problemas ou inovação.

\section{Organização Profissional}

Existem organizações que dependem das habilidades dos profissionais que nelas trabalham. Esta organização pode ser burocrática sem ser centralizada. Normalmente a estrutura está voltada a uma burocracia profissional, os conhecimentos e habilidades pessoais são notórios nestas organizações denominadas profissionais.

O treinamento formal é importante para a coordenação das habilidades visando uma padronização. Os profissionais que atuam neste tipo de organização têm mais liberdade de atuação, ou seja, trabalham com relativa independência, mas o fazem intimamente com seus clientes.

Como exemplos de organizações profissionais têm-se as universidades, hospitais, escritórios de advocacia ou trabalho artesanal. Um fato que pode diferenciar a organização profissional da organização tipo máquina é que nesta a burocracia depende da autoridade do poder do cargo enquanto na profissional o poder do expertise.

$\mathrm{Na}$ organização tipo profissional os padrões podem ser gerados fora da organização como em associações independentes a que pertencem seus profissionais com seus colegas de outras instituições.

$\mathrm{Na}$ estrutura da organização profissional o pessoal de apoio tem pouco impacto sobre os profissionais, porém dado ao alto custo destes faz sentido apoiá-los da melhor maneira possível, os fatores abaixo são importantes:

- Fatores ambientais: são variáveis e complexos ao mesmo tempo, de modo que devem dar destaque à parte que atende às condições do ambiente estável pela mudança lenta da variável tecnologia, mas que os clientes exigem atendimento personalizado.

- Parte-chave: unidade composta por especialistas de alto nível com o fim de atender diretamente os clientes que necessitam de atendimento ou as pessoas que desejam aprender alguma profissão 
- Coordenação: função de estabelecer cargas e disciplinas de horários, além de administrar conflitos e casos de exceções, sendo negativo o fato de ser frágil pela possibilidade de resistência por parte dos profissionais que alegam autonomia para os procedimentos. Padroniza as habilidades para levá-las ao efeito.

A organização profissional muitas vezes é descrita como uma pirâmide invertida, em virtude do poder de seus profissionais, estes ficam em cima e a administração em baixo para servi-los.

Pela dependência direta destes profissionais, deve ser considerado que a elaboração da estratégia em uma organização profissional não é tarefa fácil. Se elas formulassem estratégias de maneira convencional, os administradores centrais desenvolveriam planos detalhados e integrados, o que pode acontecer, mas dependeriam da aprovação dos profissionais ou participação dos mesmos tornando o processo complexo.

As características e condições de organizações profissionais estão sempre relacionadas ao domínio por funcionários hábeis, os quais usam procedimentos difíceis de aprender e que, no entanto, são bem definidos. Tem-se uma situação complexa o suficiente para requerer procedimentos que podem ser aprendidos com forte treinamento e estável para que seu uso possa tornar-se padronizado.

\section{Organização Diversificada}

Segundo Mintzberg (1979 e 2006), a organização diversificada normalmente é o resultado da diversificação de uma organização máquina, grandes corporações empresariais, com muitas unidades de negócio controladas por um escritório ou administração central. Por se entender que se pode confundir com a organização tipo máquina não foi considerada neste trabalho.

\section{Organização Inovadora ou Adhocrática}

Flexibilidade é o termo que caracteriza melhor uma organização inovadora ou adhocrática, aliás, termo popularizado na obra de Toffler (1990).

A estrutura é altamente orgânica, com pouca formalização de comportamento, cargos especializados com base em treinamentos especiais, uma tendência de agrupar os especialistas em unidades para efeito de preparação interna, porém destacando-os em pequenas equipes de projeto para realização dos trabalhos. 
A coordenação foge de qualquer forma de padronização, ou seja, das armadilhas da estrutura burocrática. A adhocracia precisa admitir e delegar poder aos especialistas, pessoas cujos conhecimentos e habilidades tenham sido amplamente desenvolvidos em programas de treinamento. Mas diferente da organização profissional, a adhocracia não pode depender das habilidades padronizadas de seus especialistas para obter a coordenação, pois isto desencorajaria a inovação.

Os projetos específicos rompem as fronteiras da especialização e diferenciação convencional, delegando problemas não para peritos, individualmente, em feudos predeterminados, mas para equipes multidisciplinares que juntam seus esforços.

Nas organizações inovadoras os limites de controle são pequenos, os gerentes raramente dão ordens, no sentido da organização tipo máquina, mas funcionam como elemento de ligação para coordenar o trabalho entre as várias equipes.

Um dos papeis mais importantes dos gerentes deste tipo de organização é a ligação com o ambiente externo, como depende de projetos e estes não são claramente definidos, a organização nunca terá certeza de onde virá o próximo projeto.

A organização inovadora é encontrada muitas vezes, em ambientes que são ao mesmo tempo dinâmicos e complexos. Um ambiente dinâmico, por ser imprevisível, exige uma estrutura orgânica e um ambiente complexo uma descentralizada, de acordo com os fatores:

- Fatores ambientais: ecossistema composto por clientes cujas necessidades são de produtos ou serviços muito variáveis e destinados a novos usos (o que exige forma não convencional). Criou-se esta estrutura para atender às pressões de fatores externos caracterizados por exigirem invenções e uso de tecnologias consideradas "high tech".

- Parte-chave: é constituída por equipes multidisciplinares interligadas, formadas por especialistas de alto nível. Caracteriza-se por ser mutável, sendo criada, modificada e desfeita segundo as exigências dos serviços ou produtos que a organização se responsabiliza.

- Coordenação: ajustamento mútuo onde os próprios membros decidem o que fazer. A linha intermediária confunde-se com a tecnoestrutura, a assessoria é necessária para fazer a folha de pagamento, contabilidade e outras atividades burocráticas e a cúpula 
estratégica fica mais voltada ao ecossistema em busca de serviços de clientes do que para operações internas. O núcleo operacional tem um papel secundário, podendo até ser terceirizado.

A estratégia numa organização inovadora não pode ser elaborada a partir de um processo de planejamento formal, principalmente por ter que reagir continuamente a um ambiente complexo e imprevisível.

A ação especifica realizada em muitos lugares é que irá definir a formação da estratégia, qualquer processo que separe o pensamento da ação, o planejamento da execução, a formulação da implementação, pode impedir a flexibilidade da organização em reagir criativamente a seu ambiente dinâmico.

Agências de propaganda, espaciais, produtoras de filmes ou empresas que trabalhem com projetos específicos, são exemplos de organizações inovadoras ou adhocráticas. São organizações jovens, que enfatizam a pesquisa e precisam inovar constantemente.

A adhocracia tem algumas dificuldades. Há certa tendência ao desperdício de tempo, porque as pessoas precisam falar muito. Apesar dessa desvantagem e da indefinição de responsabilidades, Mintzberg (1979e 2006) acredita que as vantagens são largamente superiores. É, para ele, o tipo de organização do futuro e também a mais apreciada.

\section{Organização Missionária}

A organização missionária tem como parte mais importante não uma unidade ou grupo de pessoas, mas a ideologia. A ideologia, um sistema de valores e crenças, é o elemento aglutinador que mantém unidas as partes da organização missionária. Organizações religiosas, empresas japonesas e empresas ocidentais como Amway são exemplos de organizações com a configuração missionária.

Também por se considerar organização de difícil caracterização não foi utilizada neste trabalho.

\section{Organização Política}

As organizações políticas não têm parte mais importante, nem mecanismos de coordenação geral e são caracterizadas pelo conflito. Ocorre freqüentemente em organizações públicas, 
pela dificuldade de acesso, obtenção de informações e entrevistas também não será utilizada neste projeto.

Tem-se a partir do exposto que as organizações que mais propiciam à análise são: empreendedora, máquina, inovadora ou adhocrática e profissional.

\subsubsection{As Organizações segundo Morgan (1996)}

Segundo Morgan (1996), todas as pessoas têm imagens mentais das organizações em que trabalham. Uma organização é vista de forma diferente por diferentes pessoas. A mesma pessoa também pode vê-la de diferentes maneiras. Conhecer as imagens mentais permite entender e administrar melhor as organizações. $\mathrm{O}$ autor propõe oito imagens possíveis das organizações: máquinas, organismos vivos, cérebros, culturas, sistemas políticos, prisões psíquicas, sistemas em fluxo e transformação e instrumentos de dominação.

\section{a) Máquina}

A organização imaginada como máquina enfatiza a organização e a hierarquia, procurando deixar bem claro quais são as responsabilidades e quem tem autoridade sobre quem. Lojas de cadeias de fastfood, desfiles militares e departamentos de contabilidade são freqüentemente vistos como máquinas. Disciplina, estabilidade e tratamento uniforme das pessoas são características valorizadas pela máquina. Taylor (1995) e Fayol (1994) foram advogados desse tipo de organização. Weber (1999) a descreveu em seu clássico tipo ideal, que foi retomado por Burns e Stalker (1961), Mintzberg (1979 e 2006). Para Morgan (1996), o ponto forte desse tipo de organização é o mesmo das máquinas reais: o funcionamento regular. Seu ponto fraco é não dar a devida importância aos trabalhadores.

\section{b) Organismo vivo}

O organismo vivo é a metáfora biológica das organizações. É o mesmo modelo orgânico de Burns e Stalker (1961). A ênfase está na capacidade de adaptação e não no arranjo ordenado das coisas. Os centros acadêmicos e os departamentos de criação das agências de propaganda são exemplos de organizações vivas. As tarefas e as linhas de autoridade podem ser mudadas continuamente, para permitir o alinhamento da organização com seu ambiente. Morgan (1996) aponta, como pontos fortes, à flexibilidade dos sistemas abertos e a ênfase no desenvolvimento das competências humanas, o que é particularmente apropriado para lidar 
com ambientes turbulentos e competitivos, como é o caso dos ramos de alta tecnologia. Os organismos vivos, no entanto, não são indefinidamente adaptativos. Como também apontaram outros autores, o conflito interno que é característico dos sistemas orgânicos pode levá-los à obsolescência e à extinção.

\section{c) Cérebro}

A imagem do cérebro aplica-se às organizações em que a inteligência e o conhecimento estão espalhados em todos os lugares, como acontece nas instituições de pesquisa e nas universidades. Assim, qualquer parte da organização pode reproduzir e fazer o papel do todo. Além disso, cada parte aprende por si e aprende a aprender. A aprendizagem vai além da simples correção dos erros, para chegar até o questionamento e correção das condições que provocam os erros. Nas organizações mecanicistas, essa possibilidade é reduzida. No entanto, o cérebro pode ser feito de partes que não aprendem com as outras, ou não conseguem questionar sua própria forma de trabalhar.

\section{d) Cultura}

A quarta imagem de Morgan (1996) é a das organizações como culturas. As pessoas, que compartilham uma cultura interpretam situações e eventos da mesma forma. É o que acontece nas organizações religiosas e nas que têm missões filantrópicas. A visão da cultura permite enxergar outros aspectos alem dos formais e racionais, mostrando as possibilidades de mudança. Quando uma empresa de transportes vê seus passageiros como clientes, e não como carga, a mudança de perspectiva tem impacto positivo sobre a estratégia e a competitividade.

e) Sistema Político

Como sistema político, a organização é feita de interesses de vários tipos: departamentais, grupais, pessoais e assim por diante. Além disso, pode ser democrática ou autocrítica, ou ficar em algum ponto no meio desses dois extremos. Essa idéia, que já havia sido explorada por Cyert e March (1963), mostra as empresas, e qualquer outro tipo de organização, como coalizões políticas com múltiplos objetivos que precisam ser compatibilizados. O processo de administrar organizações, segundo Morgan (1996), deve reconhecer a natureza política das organizações. 


\section{f) Prisão Psíquica}

A visão das prisões psíquicas mostra as organizações com muito maior poder sobre as pessoas do que elas na realidade têm. As pessoas ficam confinadas a seus papeis limitados e tornam-se incapazes de pensar de forma diferente da que acreditam ser a desejada pela organização. Essa ilusão ocorre apenas na mente das pessoas e pode ser rompida, de acordo com Morgan (1996). Por isso, e responsabilidade dos gerentes derrubarem as barreiras mentais e interpretar de maneira diferente suas tarefas e a organização em que trabalham.

\section{g) Sistema em fluxo e transformação}

A sétima imagem de Morgan (1996) e a das organizações em continuo processo de mudança e intercambio com o ambiente, Essa imagem permite enxergar a necessidade de adaptação para a sobrevivência, em que a influencia e recíproca, entre a organização e o ambiente. Todas as organizações são sistemas que funcionam como fluxos, processos, interagindo com o ambiente, e transformam-se para adaptar-se. A incapacidade de transformação torna a organização ineficaz e condena-a a extinção.

h) Instrumento de dominação

A última imagem de Morgan (1996) mostra as organizações como instrumentos de dominação. Os grandes empreendimentos, como a construção da Muralha da China, ou a Pirâmide de Quéops, são demonstrações do triunfo da técnica e da habilidade, e também do sacrifício de muitos para a glória de poucos. As organizações têm poder e o utilizam para beneficiar-se, muitas vezes causando danos a seus empregados, ao ambiente e à sociedade.

Na obra de Morgan (1996) também algumas relações podem ser estabelecidas: há um nome em comum com os outros trabalhos que é a organização tipo máquina, a caracterização de organismo vivo com a empresa inovadora, cérebro com a profissional e instrumento de dominação com a empreendedora. As outras metáforas se misturam e algumas como exposto anteriormente não serão abordadas no projeto.

Um quadro resumo na síntese da revisão da literatura lista os modelos ou tipologias em comum nos vários autores pesquisados e define a base para o estudo. 


\subsection{Síntese do referencial teórico}

As organizações podem estabelecer relações de análises dentro da visão de fora para dentro, mais tradicional, ou uma visão mais atualizada de dentro para fora.

O gerenciamento dos recursos tangíveis e intangíveis pode estar relacionado à evolução da estratégia e outros atributos nos modelos organizacionais.

O processo de desenvolvimento do planejamento estratégico pode passar por várias etapas, porém as mais utilizadas dentro das escolas escolhidas para o projeto são: definição de missão e visão, análises dos ambientes externos e internos, elaboração dos objetivos e estratégias, viabilidade do plano, implantação com os planos de ação e mecanismos de avaliação e controle.

As estruturas organizacionais devem ser estabelecidas de acordo com as estratégias e podem variar nos modelos organizacionais.

A avaliação organizacional deixou de ser uma série de indicadores financeiros e passou a levar em consideração outros fatores importantes para a competitividade e efetividade da organização.

A partir do referencial teórico pretende-se chegar aos atributos que irão caracterizar as organizações e como estas desenvolvem o planejamento estratégico dentro das linhas de pensamento dos autores expostos no referencial teórico. De acordo com o exposto no referencial teórico, as tipologias mais comuns e base para o projeto de pesquisa são as organizações tipo: empreendedora, máquina, profissional e inovadora ou adhocrática.

O Quadro 6 resume os autores e modelos ou tipologias estabelecidas pelos mesmos, base para se chegar as variáveis independentes. 
Quadro 6 - Resumo dos modelos, tipologias organizacionais

\begin{tabular}{|l|l|l|}
\hline \multicolumn{1}{|c|}{ Autores } & \multicolumn{1}{|c|}{ Tipos de Organizações } & Tipologias comuns aos autores \\
\hline Mooney (1947) & Linear (empreendedora) & \\
Funcional (máquina) & \\
Murns e Stalkler (1961) & Linha-staff (inovadora) & \\
& Mecanicista & \\
Orgânica & Empreendedora \\
2006) & Empresarial (empreendedora) & Máquina \\
& Máquina & Profissional \\
& Profissional & Inovadora ou adhocrática \\
& Diversificada & \\
& Inovadora ou adhocrática & \\
& Missionária & \\
Morgan (1996) & Política & \\
& Máquina & \\
& Organismo Vivo (adhocrática) & \\
& Cérebro (profissional) & \\
& Cultura & \\
& Sistema político & \\
& Prisão psíquica & \\
& Sistema em fluxo e transformação & \\
& Instrumento de dominação (empreendedora) & \\
\hline
\end{tabular}





\section{PROCEDIMENTOS METODOLÓGICOS}

Este capítulo explica a metodologia de pesquisa adotada e descreve os procedimentos de pesquisa utilizados. A presente pesquisa terá uma abordagem predominantemente explicativa ou interpretativa, com o tratamento dos dados predominantemente qualitativo; foi realizada ex-post facto, numa perspectiva transversal em termos temporais e utilizou-se o método de estudo de casos múltiplos.

\subsection{Método ou delineamento da pesquisa}

De acordo com seus objetivos as pesquisas podem ser classificadas em três categorias: exploratória, descritivas e explicativas (SELLTIZ et al, 1974; GIL, 2005; HAIR et al, 2005).

$\mathrm{Na}$ pesquisa exploratória, o objetivo é aproximar-se do fenômeno ou conseguir nova compreensão dele, freqüentemente, para que pesquisas futuras consigam formular um problema mais preciso de pesquisa ou criar novas hipóteses. A pesquisa descritiva apresenta, precisamente, as características de uma situação, ou então estabelece relações entre variáveis.

Já a pesquisa explicativa procura verificar uma hipótese de relação causa e efeito entre variáveis ou está destinada a responder as causas dos acontecimentos, fatos e fenômenos físicos ou sociais, seu interesse está em responder por que e em quais condições um fenômeno ocorre e em quais condições ou por que duas ou mais variáveis estão relacionadas (SELLTIZ et al, 1974, GIL, 2005, SAMPIERI et al, 2006). Yin (2007) considera um estudo explicativo aquele que consiste em uma interpretação cuidadosa dos fatos, algum tipo de consideração sobre explicações alternativas a respeito desses fatos e uma conclusão baseada naquela explicação que parece mais congruente com os fatos.

Godoy (2006) além de classificar como pesquisa descritiva utiliza a denominação interpretativa que vai além de conter uma rica descrição do fenômeno estudado, buscando padrões nos dados e desenvolvendo categorias conceituais que possibilitem ilustrar, confirmar ou opor-se a suposições teóricas. Deve-se ressaltar que as pesquisas podem possuir características de mais de uma das categorias citadas acima, pois essas não são mutuamente excludentes.

Relacionar os modelos organizacionais ao processo de desenvolvimento do planejamento estratégico vai além de um estudo exploratório, pois algumas proposições já foram 
estabelecidas na revisão da literatura, assim como não será somente descrita uma relação entre variáveis e sim responder a indagações de como os diferentes modelos lidam com o processo de planejamento estratégico, quais as visões que prevalecem em cada modelo, qual processo ou etapa, passos e ações estão mais adequados a cada um deles. Assim configura-se um estudo explicativo de acordo principalmente com Yin (2007) e pode-se aproveitar a denominação de Godoy (2006) interpretativo, as duas classificações têm similaridades ou se completam.

O tratamento dos dados nos fornece outra forma de classificar o método de pesquisa, que pode ser quantitativa ou qualitativa (GODOY, 1995a e 1995b; RICHARDSON, 1999). O estudo quantitativo caracteriza-se a partir de um plano de pesquisa pré-estabelecido, com hipóteses claramente especificadas procurando enumerar e medir os eventos estudados pelas mais variadas técnicas estatísticas. Já no estudo qualitativo o pesquisador parte de questões e interesses mais amplos que vão se configurando à medida que o estudo se desenvolve, o objeto de estudo passa a ser a descrição do contexto do problema em questão, analisado sob a perspectiva dos participantes envolvidos na questão em estudo (GODOY, 1995a). Richardson (1999) complementa que a pesquisa qualitativa é adequada quando se pretende investigar eventos em profundidade.

Por se tratar de um estudo que lida principalmente com aspectos intangíveis da organização e requer entrevistas mais aprofundadas optou-se por um estudo qualitativo, o que não descarta no futuro um estudo quantitativo quando os atributos das pesquisas passarem por ajustes para estabelecerem as relações com amostras estatísticas.

A pesquisa não sofrerá interferência do pesquisador e as variáveis independentes não são manipuláveis, principalmente porque o fato já ocorreu, ou seja, os eventos estão finalizados caracterizando o ex-post-facto.

Como a coleta dos dados se dará em um ponto determinado no tempo a pesquisa será transversal, caso fosse realizada em momentos distintos seria um estudo longitudinal (GIL, 2007).

Quanto à sua estrutura, o estudo está dividido basicamente, em torno de duas partes bem definidas:

- A pesquisa de dados secundários realizados por meio da revisão da literatura;

- A pesquisa de dados primários que foi realizada por meio de pesquisa de campo. 
A revisão da literatura buscou levantar um arcabouço teórico sobre o tema para satisfazer os principais objetivos. Primeiro, estabelecer, discutir e consolidar as etapas, análises e passos para o processo de desenvolvimento do planejamento estratégico. Segundo caracterizar os modelos organizacionais definindo os atributos para cada modelo. A pesquisa de campo, cuja classificação é explicativa, buscará encontrar evidências que confirmem ou não as proposições iniciais.

Existem diversos métodos de pesquisas aceitas para se atender aos objetivos da pesquisa explicativa. Godoy (1995b) divide os possíveis métodos de pesquisa em documental; estudo de caso, e etnográfica. Marshall e Rossman (1999) acrescentam a esta lista a teoria fundamentada ou grounded theory, pesquisa-ação, dentre outros.

Segundo Hartley (1994), o estudo de caso consiste em uma investigação detalhada, com a coleta de informações de um ou mais organizações ou grupos, com a visão de conseguir analisar o contexto e os processos envolvidos no fenômeno de estudo. $\mathrm{O}$ autor escreve que o estudo de caso é uma estratégia e não simplesmente um método de pesquisa.

Eisenhardt (1999) descreve o estudo de caso como uma estratégia de pesquisa que se concentra na compreensão das dinâmicas presentes em cenários únicos, combinando métodos de coleta como análise de documentos, entrevistas, questionários e observações, podendo a evidência ser quantitativa, qualitativa ou ambas, apesar de que os métodos qualitativos são mais empregados.

Yin (2007) argumenta que o estudo de caso é uma das muitas maneiras de se fazer pesquisa em ciências sociais. Essa estratégia de pesquisa é utilizada quando questões do tipo "como?" e “por quê?” são colocadas, quando o pesquisador tem pouco controle sobre o evento pesquisado e quando o foco se encontra em fenômenos contemporâneos inseridos num contexto da vida real.

Para Stake (1994), o estudo de caso não é um método. Mas a escolha de um objetivo a ser estudado. O estudo de caso pode ser único ou múltiplo e a unidade de análise pode ser um ou mais indivíduos, grupos, organizações, eventos, países, ou regiões.

Alguns autores como Eisenhardt (1999) e Yin (2007) também preocuparam-se com a construção de teorias por meio de casos privilegiam o uso de casos coletivos. Entretanto para Platt (1988), mesmo quando mais de um caso for pesquisado, a individualidade de cada caso é 
retirada e o número de casos em si não é considerado significativo. Alguns aspectos caracterizam o estudo de caso como uma estratégia de pesquisa, permite o estudo de fenômenos em profundidade dentro do seu contexto, é especialmente adequado ao estudo de processos e explora fenômenos com base em vários ângulos.

Assim, pelo exposto, optou-se por um estudo de casos múltiplos, pois a questão de pesquisa está relacionada à “como?” e o foco se encontra em fenômenos contemporâneos inseridos num contexto organizacional.

Foram estudadas duas organizações de cada tipologia dos modelos definidos, num total de oito empresas, de grande e médio porte. Não foi imposta a condição dos modelos pertencerem ao mesmo setor de atividades.

\subsection{Modelo conceitual e operacionalização das variáveis}

O modelo conceitual desta pesquisa é composto por três vertentes principais identificadas na Figura 4.

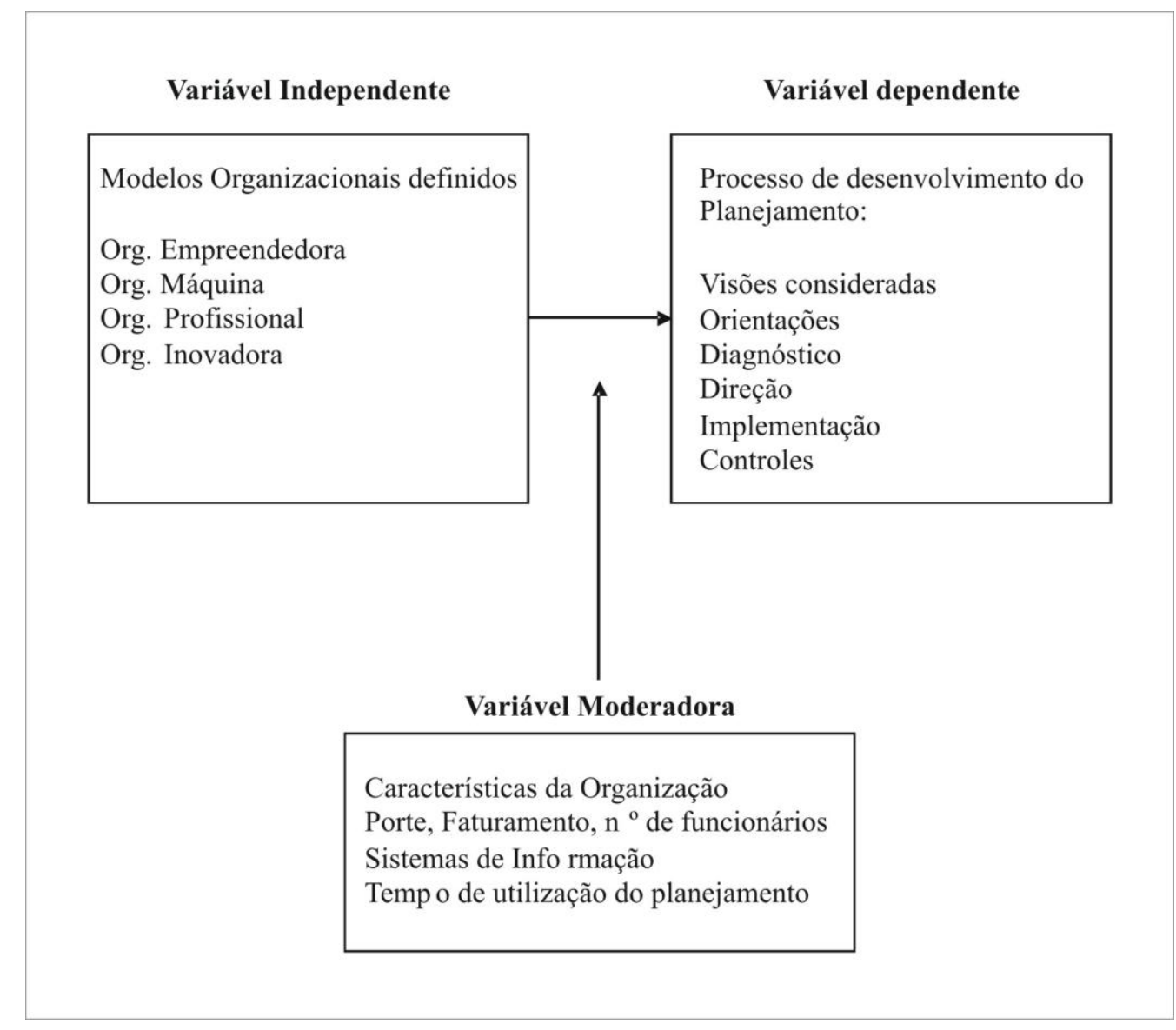

Figura 4 - Modelo conceitual do projeto de pesquisa 
A estruturação lógica da pergunta de pesquisa, além de ter fundamentado o modelo conceitual da pesquisa, fundamentou também a elaboração de algumas proposições que são estudadas empiricamente neste trabalho.

P1: Organizações tipo empreendedora tendem a visões de curto prazo ou sem desenvolvimento do planejamento

P2: Organizações tipo máquina tendem a desenvolver o planejamento considerando a visão de fora para dentro.

P3: Organizações tipo profissional tendem a desenvolver o planejamento considerando os públicos interessados.

P4: Organizações tipo inovadora ou adhocrática tendem a desenvolver o planejamento considerando a visão de dentro para fora.

As proposições estabelecidas relacionam a variável independente a variável dependente e seguem os conceitos.

\subsubsection{Definições conceituais e operacionais das variáveis}

Eisenhardt (1999) recomenda a elaboração de variáveis ligadas ao problema de pesquisa para a delimitação do estudo e seu conceito é definido por Marconi e Lakatos (2003, p. 137) como:

Uma variável pode ser considerada como uma classificação ou medida; uma quantidade que varia; um conceito operacional, que contém ou apresenta valores; aspecto, propriedade ou fator discernível em um objeto de estudo e passível de mensuração.

Para este estudo trabalhou-se com três diferentes tipos de variáveis: independente, dependente e moderadora. De acordo com Marconi e Lakatos (2003, p. 138), variável independente "é aquela que influencia, determina ou afeta outra variável [...]”. Já a variável dependente “[...] consiste naqueles valores, fenômenos, fatores a serem explicados ou descobertos, em virtude de serem influenciados, determinados ou afetados pela variável independente [...]”. Marconi e Lakatos (2003, p. 138) afirmam ainda que “[...] a variável independente é o antecedente e a variável dependente é o conseqüente[...]”.

A variável moderadora são fatores que podem modificar a relação entre as variáveis independente e dependente. É geralmente utilizada em pesquisas cujos problemas são complexos e possuem fatores inter-relacionados. Marconi e Lakatos (2003, p. 144) a definem como: 
Um fator, fenômeno ou propriedade, que também é condição, causa estímulo ou fator determinante para que ocorra determinado resultado, efeito ou conseqüência, situando-se, porém no nível secundário no que respeita a variável independente [...] é selecionado, manipulado e medido pelo investigador, que se preocupa em medir se ela tem ou influência ou modifica a relação da variável independente com o fator ou fenômeno observado (variável dependente).

A definição ou operacionalização é feita através de adição de valores às variáveis "[...] acompanhados de um conjunto de instruções que permitam atribuir um valor determinado a uma unidade de análise determinada." (SELLTIZ et al, 1974, p. 1). Segundo Marconi e Lakatos (2003 p. 137) esses valores "[...] podem ser quantidades, qualidades, características, magnitudes, traços, etc. que se alteram em cada caso particular e são totalmente abrangentes e mutuamente exclusivos [...]".

A revisão da literatura apresentada nos primeiros tópicos desta tese forneceu subsídios para definição operacional das variáveis que colaborarão para a resposta aos objetivos propostos.

Variável independente, linhas de pensamento, Mooney (1947), Blau e Scott (1970), Etzioni (1974), Mintzberg (1979 e 2006), Morgan (1996) e outros.

Variável dependente, linhas de pensamento, Fischmann e Almeida (1991), Almeida (1997, 2003, 2004), Thompson e Strickland (2000), Wrigth (2000), Hitt et al (2002 e 2008), Heijden (2005), Certo et al (2005), Mintzberg (2004 e 2006), Almeida e Benny (2007) e Kluyver e Pearce (2007).

Variável moderadora, indicadores das características da organização que podem modificar a relação entre as outras variáveis levantadas nas entrevistas e pesquisa de dados secundários disponibilizados pelas empresas.

\subsubsection{Operacionalização da variável independente}

Atributos característicos de acordo com o referencial teórico, para modelo de organização tipo empreendedora.

- Sua empresa é dirigida por um proprietário ou sócio gerente.

- As estratégias e os objetivos são elaborados por este proprietário ou tem sua participação direta.

- Existe pouco planejamento e treinamento. 
- As políticas internas são alteradas conforme o desejo do proprietário ou sócio gerente.

Atributos característicos de acordo com o referencial teórico, para modelo de organização tipo máquina.

- A empresa rotiniza as tarefas e possibilita controle por meio de regulamentos.

- O poder está dividido entre a alta gerencia e os técnicos especializados.

- Sua empresa é caracterizada por tamanho, trabalho repetitivo e ambiente estável.

Atributos característicos de acordo com o referencial teórico, para modelo de organização tipo profissional.

- A base do conhecimento se dá na gestão do conhecimento, com especialista tipo professor, médico ou advogado.

- A empresa é dominada por especialistas com treinamento avançado, que apreciam a autonomia e exercem atividades que exigem habilidades técnicas.

- A maioria dos profissionais é independente e a demanda por seus serviços é elevada.

- A estrutura da organização tende a democracia.

Atributos característicos de acordo com o referencial teórico, para modelo de organização tipo inovadora ou adhocrática.

- Sua empresa se caracteriza pela ênfase na pesquisa e desenvolvimento.

- Sua empresa é considerada uma organização jovem e inovadora.

- Sua empresa prima pela busca de novos conhecimentos. 


\subsubsection{Operacionalização da variável dependente}

Atributos relacionados ao processo de desenvolvimento do planejamento estratégico:

- Sua empresa estabelece claramente as etapas, análises e passos para o desenvolvimento do planejamento estratégico.

Dentro desses pode-se encontrar:

- A definição do negócio clara a partir da missão e visão.

Elabora algum tipo de diagnóstico (SWOT), sendo:

- Leva em consideração os fatores do ambiente para definição de estratégias.

- Analisa os fatores mais amplos como variáveis econômicas, sociais, culturais, políticas, demográficas, ecológicas e outras.

- Analisa os fatores que estão mais próximos da organização como: poder de algum fornecedor, poder de grandes clientes, produtos alternativos, novos concorrentes e todos os concorrentes diretos.

- Analisa o dinamismo do mercado que está inserida.

- Gerencia os recursos internos para a busca de vantagens competitivas e consegue identificar recursos internos raros, difíceis de imitar ou alguma competência única conhecida como competência essencial.

- As estratégias usadas na sua empresa são fáceis de serem compreendidas e disseminadas.

- Pode-se dizer que sua empresa tem um posicionamento estratégico para diferenciação, baixo custo ou foco em algum segmento de mercado específico.

- Os objetivos são estabelecidos para o curto, médio e longo prazo.

- O que considera curto, médio e longo prazo.

- Estruturas organizacionais são continuamente questionadas e reconsideradas na sua empresa. 
- Existem planos de ação definidos por área funcional ou outro tipo de estrutura para implementação das estratégias e para atingir os objetivos.

- Sua empresa tem mecanismos de avaliação e controle e se os têm quais são.

- Existe a possibilidade de fornecer algum documento que comprove as etapas, análises e passos para o processo de desenvolvimento do planejamento estratégico sem comprometer a confidencialidade da organização.

\subsubsection{Operacionalização da variável moderadora}

Atributos da variável moderadora:

- Características da organização: porte, faturamento, número de funcionários.

- Sistemas de informação, qual e como é disseminado.

- Tempo de utilização do planejamento.

\subsection{Universo da pesquisa, seleção dos casos e da unidade de análise}

A especificação da população é um requisito fundamental para a seleção do estudo de caso. Segundo Eisenhardt (1999) isto reduz as variações e dá clareza aos resultados.

O universo da pesquisa foi restrito as organizações privadas por conveniência desde que se cumpram os critérios das variáveis, e os casos foram selecionados de acordo com os atributos levantados na operacionalização da variável independente, ou seja, as tipologias definidas entre as similaridades dos autores pesquisados.

De acordo com os critérios de lógica de replicação na abordagem de casos múltiplos, já citados anteriormente, é necessário que se tenham, além de casos comparáveis (conseguido através da similaridade entre os casos), unidades de análises comparáveis. Então, na prática, após a caracterização dos modelos, as organizações terão que obedecer a alguns critérios de seleção que visam garantir a homogeneidade, como similaridades da variável moderadora.

As organizações foram escolhidas com base nas tipologias definidas, caso haja modelos híbridos, optou-se por aquele que tem a maior predominância. 
Organização tipo empreendedora:

- SBT ou Sistema Brasileiro de Televisão, com autorização concedida pelo Diretor Financeiro Sr. José Roberto Maciel.

- Transportadora Granero, com autorização concedida pelo Diretor Financeiro Sr. Everton Granero

Organização tipo máquina:

- Owens-Illinois do Brasil S.A., antiga Cisper, com autorização concedida pelo Diretor de Marketing e Vendas Sr. Rildo Lima.

- Embraer, com autorização concedida pelo Vice-Presidente Comercial Engenheiro Luiz Affonso.

Organização tipo Inovadora:

- F/Nazca Saatchi \& Saatchi Agência de Publicidade, com autorização concedida pelo Diretor de Planejamento Sr. Fernand Alphen.

- Vivo telefonia celular, com autorização concedida pelo Diretor Comercial da Regional São Paulo, Sr. Antonio Carlos Cipriano.

Organização tipo profissional:

- Fundação Armando Álvares Penteado (FAAP), com autorização concedida pelo Diretor da Faculdade de Administração Professor Henrique Vailati Neto.

- Hospital Carlos Chagas, com autorização concedida pelo sócio proprietário Dr. Antonio Carlos Garcia. 


\subsection{Técnica de coleta de dados e procedimentos operacionais}

Foram utilizadas entrevistas, com roteiro semi-estruturado e observação direta. A entrevista em profundidade é aquela em que o entrevistador segue um roteiro previamente estabelecido, ou seja, as perguntas feitas ao entrevistado são pré-determinadas. O motivo da padronização é obter dos entrevistados diversas respostas às mesmas perguntas, permitindo que elas sejam comparadas com o mesmo conjunto de perguntas e que as diferenças reflitam diversidades entre os respondentes e não diferenças nas perguntas (MARCONI; LAKATOS, 2003).

As entrevistas foram realizadas em duas etapas, a primeira para caracterização do modelo para aprovação ou não da amostra e a segunda com os atributos que relacionam os modelos ao processo de desenvolvimento do planejamento estratégico.

Foi entrevistado um diretor de área responsável pelo processo de desenvolvimento do planejamento estratégico como, marketing, comercial ou financeiro e pelo menos dois gerentes de duas áreas responsáveis também pelo mesmo processo. Foram entrevistados três colaboradores para cada tipo de organização, de três departamentos estabelecendo uma triangulação.

A observação direta deu-se a partir do comportamento e atividades relacionadas ao processo de desenvolvimento do Planejamento Estratégico levantados no período mínimo de três dias em cada organização.

Foram solicitados os relatórios que compõe o plano estratégico que é o resultado do planejamento. Mas como muitas vezes são considerados confidenciais somente duas organizações os disponibilizaram.

Visando a obtenção de dados consistentes e resultados fidedignos, os entrevistados foram informados a priori que:

- A pesquisa poderá ser mantida em confidencialidade.

- Será preservada a confidencialidade dos seus nomes no caso da publicação de artigos.

- Será oferecida a confidencialidade dos nomes das empresas.

- Todas as entrevistas serão gravadas (mediante aceitação do entrevistado). 
- A aplicação do instrumento de coleta de dados será não disfarçada e será o mesmo para todas as empresas.

- A transcrição das entrevistas será realizada em no máximo 36 horas após cada entrevista.

- Novos dados secundários podem ser estudados para triangulação e validação das entrevistas.

- O relatório final individual de cada empresa será retornado para o entrevistado (via email) com a finalidade de validar as informações.

\subsection{Procedimento para análise dos dados}

Yin (2007) sugere três estratégias para analisar os dados coletados:

- Proposições teóricas - confrontação de dados coletados com as proposições derivadas da teoria (segundo o autor a melhor estratégia de análise).

- Explanações concorrentes - comparação dos resultados com proposições teóricas concorrentes, onde se uma explanação for válida, as outras não podem ser.

- Descrição do caso - desenvolve uma estrutura descritiva para organizar o estudo do caso.

Para este estudo utilizou-se a estratégia geral de proposição teórica. O objetivo foi de analisar e organizar os dados a partir das proposições estabelecidas na revisão teórica. 


\subsection{Validade e confiabilidade}

Para Musson (1998), a validade é atingida por meio da congruência das explicações de pesquisa com os significados que os membros constroem sobre suas realidades, assim os entrevistados serão selecionados de acordo com o tempo de trabalho nas empresas, no mínimo dois anos, e suas relações com o processo de desenvolvimento do planejamento estratégico, como participação nas reuniões que antecedem o processo de planejamento e importância nas tomadas de decisão. Qualquer entrevistado que não tenha requisitos mínimos de atuação na organização ou influência na elaboração do planejamento e tomada de decisão será descartado da análise.

Yin (2007) estabelece alguns testes que visam aumentar a qualidade da pesquisa:

Validade de constructo: a validade de construto tenta trazer evidências de variadas fontes para prover múltiplas mensurações sobre o mesmo, ou seja, diz respeito ao estabelecimento de medidas operacionais corretas, definições operacionais, para medir os conceitos a serem estudados ou variáveis. $\mathrm{O}$ autor cita três táticas disponíveis para aumentar a validade de construtos:

- Uso de múltiplas fontes de dados - garantindo evidências de uma variedade de fontes garante múltiplas mensurações sobre o mesmo fenômeno.

- Estabelecimento de uma cadeia de evidências - isso pode ser realizado através do cruzamento dos dados coletados com a literatura revisada.

- A revisão do relatório pelos informantes chaves: isso possibilita que a participação dos informantes seja incluída no relatório final.

A validade do constructo se dá a partir das fontes múltiplas de evidências, com os autores pesquisados e estabelece encadeamento destas evidências, das linhas de pensamentos estabelecidas pelas variáveis dependentes e independentes.

\subsubsection{Limitações do estudo}

Além das limitações colocadas na situação problemática, este estudo apresenta as limitações clássicas dos estudos qualitativos. A impossibilidade de generalização estatística é uma delas. Por isso mesmo, as conclusões deverão se restringir ao contexto das indústrias pesquisadas e às especificidades das empresas-casos estudadas. 



\section{ESTUDO DE CASOS MÚLTIPLOS}

Tem-se a seguir o propósito de: caracterizar o modelo organizacional de acordo com os atributos definidos para cada modelo.

Discutir e consolidar as etapas, análises e passos estabelecidos para o processo de desenvolvimento do planejamento estratégico.

Identificar as relações do processo de desenvolvimento do planejamento estratégico em cada modelo Organizacionalo.

Analisar as relações entre o processo de desenvolvimento do planejamento estratégico e os modelos organizacionais.

As visitas e entrevistas foram realizadas no período de março a outubro de 2009, oito empresas no total, 24 entrevistados com mais de 60 horas de entrevistas gravadas e em média 90 horas de visita. Todos os entrevistados têm mais de dois anos de empresa e participam diretamente na elaboração e desenvolvimento do planejamento estratégico.

Para as análises e conclusões optou-se por utilizar o substrato das entrevistas, assim como uma consolidação do que foi dito pelos entrevistados e observado pelo pesquisador.

\subsection{SBT - Sistema Brasileiro de Televisão}

O histórico da empresa foi fornecido pelos entrevistados, porém está disponível na Internet no site da organização (SBT, 2009).

\subsubsection{Apresentação da empresa}

Em 1976, Silvio Santos iniciou a operação do Canal 11 do Rio de Janeiro, denominada TVS, embrião do SBT. A partir desse canal, cuja programação era baseada em filmes e desenhos, começou a realizar seu sonho. No pequeno estúdio do bairro de São Cristóvão, começaram a serem produzidos os primeiros programas da TV de Silvio Santos. 
Silvio Santos foi em frente até obter uma concessão do governo federal e ser autorizado a assumir mais quatro emissoras remanescentes da rede Tupi: TV Tupi, TV Marajoara, TV Piratini e TV Continental.

Em 19 de agosto de 1981 nascia o Sistema Brasileiro de Televisão, que entrou no ar imediatamente, inaugurando sua programação com a transmissão da assinatura de contrato entre Silvio Santos e o governo federal, representado pelo então presidente Ernesto Geisel e o Ministro das Comunicações, Euclides de Oliveira.

Obrigado por lei a preencher 12 horas de programação diária, o Sistema Brasileiro de Televisão começou a se apresentar ao público por meio de filmes e desenhos, um pouco de jornalismo e obviamente o Programa Silvio Santos.

Logo vieram, "Moacyr Franco Show", "O homem do sapato branco", "Povo na TV" e "Alegria". O SBT alcançou rapidamente uma posição de destaque em audiência, chegando a uma participação de $24 \%$ no seu primeiro ano de operação.

Entre 1983 e 1987, na fase definida como popular, foram apresentados os programas de Flávio Cavalcanti e Hebe Camargo, a série "Joana", com Regina Duarte, a minissérie internacional "Pássaros Feridos", estrelada pelo ator Richard Chamberlain e uma cuidadosa seleção de filmes de sucesso.

De 1988 a 1990 passou a buscar qualidade de audiência através da contratação de profissionais como Boris Casoy, Jô Soares e Carlos Alberto de Nóbrega.

No final da década de 80, o SBT entrou na quarta fase de sua existência, com as estréias dos programas "Aqui Agora", "Programa Livre", "Jô Onze e Meia", e a participação no jornalismo de nomes como Bóris Casoy, Alberto Tamer e Hermano Henning. Consolida-se a "A Praça é Nossa", "Cinema em Casa" e o núcleo de dramaturgia, cujo maior sucesso foi a novela "Éramos Seis".

O SBT entrou nos anos 90 com $21 \%$ de participação em audiência e um faturamento de quase 140 milhões de dólares. Terminava a fase do sacrifício.

Surge então em 1995 o Complexo Anhanguera, grande passo para a concretização do Projeto SBT Ano 2000. 
Instalado no quilômetro 19 da Rodovia Anhanguera em um terreno de 231 mil metros quadrados, sendo 62 mil de área construída, o Complexo Anhanguera é a verdadeira "Cidade da Televisão".

Com um investimento de 120 milhões de dólares, o SBT dotou sua nova sede de toda infraestrutura necessária para garantir a qualidade de produção: equipamentos de última geração, restaurante, lanchonete, agência bancária, loja de conveniência, barbearia, ambulatórios médico e odontológico, estacionamento e transporte interno. São 2500 pessoas que circulam diariamente pelo Complexo Anhanguera.

\section{Caracterização no modelo, análises e considerações}

O SBT é dirigido pelo sócio proprietário, Sr. Senor Abravanel ou mais conhecido como Silvio Santos, as estratégias e objetivos são elaboradas por ele ou tem sua participação direta e as políticas internas são alteradas conforme seu desejo.

Nos últimos onze anos a organização passou por cinco ciclos de gestão, que são realizados com o afastamento de sócio proprietário, onde um profissional de mercado assume o controle e tenta implementar planejamento e treinamento forte, porém com o passar do tempo o sócio proprietário sente falta da operação e volta para a organização afastando o profissional e impondo sua maneira de gerir.

Diante destas colocações a organização se caracteriza como uma empresa tipicamente empreendedora. Além do sócio proprietário muitos funcionários que começaram com o Sr. Silvio Santos têm uma veia empreendedora muito forte, desprezando passos importantes para implementação de projetos como fontes de recursos ou sem muito planejamento. A percepção do proprietário e que ninguém sabe fazer o que ele sabe fazer.

\subsubsection{Dados coletados}

As entrevistas foram realizadas no complexo Anhanguera entre os dias 13 e 24 de julho de 2009, com os seguintes diretores: Sr. José Roberto dos Santos Maciel, diretor financeiro. Sr. Fernando Justos Fischer, diretor de operações comerciais. Sr. Roberto Franco, diretor técnico. 


\subsubsection{Como a organização desenvolve o planejamento estratégico}

Apesar de não apresentar um planejamento formal estruturado e contínuo algumas etapas são realizadas, existe uma definição de negócio clara a partir da visão e missão, com elaboração de diagnóstico tipo SWOT, porém a dificuldade é convencer o sócio proprietário que alguns fatores estão diferentes de suas crenças, ocasionando um desgaste entre o corpo diretivo e o mesmo.

Muitas coisas não são apresentadas como estratégicas e sim de forma tática, ou seja, a cada dia é apresentada uma ação que no final tende a configurar a estratégia pré-estabelecida sem o proprietário perceber, pois a palavra estratégia assusta muito na organização.

O diagnóstico é feito por área, os fatores do ambiente são considerados, porém as ações são de curto prazo principalmente pelo modelo de negócio, televisão, que não pode estocar o tempo. A programação tem que estar pronta na hora de entrar no ar e isto não permite muito planejamento de longo prazo.

A rotina operacional é muito pesada e cabem aos gestores direcionarem a organização para onde eles desejam. Hoje a organização tem orçamento anual, previsão de gastos, ajustes de fluxo de caixa, porém o sócio proprietário, pelas palavras dos entrevistados, funciona como o coração da empresa só que um dia ele aperta e não bombeia sangue para lugar nenhum, e no outro dia ele solta tudo de uma vez e pode ocasionar uma hemorragia.

A organização não tem grandes problemas com fornecedores, por ser verticalizada, porém sofre grande influencia dos clientes, pois o mercado está concentrado em uma emissora de televisão, Rede Globo, que tem em média $75 \%$ do orçamento dos anunciantes e o resto é dividido entre as outras emissoras.

Os produtos alternativos vêm dos novos formatos de mídia eletrônica, como Internet e o celular, e os concorrentes diretos são analisados diariamente a partir da audiência.

Pelo fato de ter poucos players e grande concentração e uma única emissora, o mercado não apresenta grande dinamismo.

A organização tem dificuldade de identificar recursos internos raros e difíceis de imitar, e as estratégias não são fáceis de serem compreendidas e disseminadas principalmente pela ação do sócio proprietário. 
O SBT posiciona-se como uma organização diferenciada, tentando competir diretamente com o líder do mercado, com a mesma competência e seriedade.

Os objetivos são estabelecidos para o curto prazo, 12 meses à frente e o médio prazo no máximo dois anos.

O SBT é a única empresa de mídia no Brasil que publica balanço, principalmente pela transparência. Sua estrutura é continuamente questionada e submete-se ao gosto do sócio proprietário.

Os planos de ação são definidos para a execução das táticas por uma coordenação de atividades, com grande capacidade de entrega principalmente pelo domínio da operação. Pelas palavras dos entrevistados eles fazem o "possilvio" para entregar toda a demanda de serviços que a organização necessita.

Os mecanismos de avaliação e controle são feitos a partir de quatro relatórios principais, rentabilidade por produto, gênero e faixa horária, relatório de performance mensal total da empresa e área por área.

A organização é considerada de grande porte, seu faturamento anual esta por volta de $\mathrm{R} \$$ 850.000.000,00, com 2.300 funcionários diretos e 700 terceirizados. O sistema de informação atual é da IBM Cognus, e a base de ERP da Oracle. Também utiliza várias ferramentas de Inteligência de Mercado com aplicativos da Microsoft. 


\subsection{Granero Transportes Ltda.}

O histórico da empresa foi fornecido pelos entrevistados.

\subsubsection{Apresentação da empresa}

Em 31 de março de 1.967, o Sr. Pedro Granero, auxiliado por alguns colaboradores, fundou, no bairro do Belenzinho - São Paulo, a "GRANERO \& FILHOS LTDA." Empresa entregadora cujos principais clientes eram Monark e Goodyear.

Em 1973, a Granero adquiriu seus primeiros veículos zero quilometro. Comprou quatro caminhões Mercedes Benz e foi subcontratada por uma grande empresa de transportes de mudanças. Esta experiência fez com que abrisse sua primeira Divisão de mudanças locais e a expansão era estimulante.

Em 1978, com o fechamento de um contrato com as Forças Armadas, inauguraram-se as primeiras filiais no Rio de Janeiro, Brasília, Salvador e Recife. Posteriormente foram implantadas unidades em todo o País, completando até 1993, 34 Filiais no Brasil. Qualquer lugar do território nacional pode ser atendido pela Granero.

Em 1993, por se tratar de uma marca forte no mercado, a Granero transformou algumas de suas filiais em franquias. O processo foi tão bem sucedido que resolveu implantar o novo sistema em todas as suas filiais. Contando atualmente com 54 franquias em todo o Brasil, a empresa objetiva 70 Unidades no médio prazo.

A partir de 1997, os sócios fundadores enxergaram outras oportunidades no mercado de transporte brasileiro pelo crescimento da indústria. Com isto, originou-se a G-tech, G-log, Ginter, G-arts, Revitech e a Living Brazil, empresas que visam à qualidade e eficiência, objetivando oferecer o melhor custo-benefício para seus clientes.

\section{Caracterização no modelo, análises e considerações}

A Granero Transportes é dirigida pelos sócios proprietários, Sr. Bernardo Granero e Sr. Roberto Granero, as estratégias e objetivos são elaboradas por ele ou tem sua participação direta e as políticas internas são alteradas conforme seu desejo. 
Os sócios proprietários pertencem a um conselho que direciona a organização e as ações diárias são elaboradas por gerentes nas várias unidades. O planejamento, quando existe é de curto prazo e voltado para as oportunidades do momento. Por exemplo, diante do presente cenário os sócios decidiram minimizar custos para se encaixar nos parâmetros do mercado.

Diante destas colocações a organização se caracteriza como uma empresa tipicamente empreendedora.

\subsubsection{Dados coletados}

As entrevistas foram realizadas nos escritórios da Av. Presidente Altino no 1879, Jaguaré, e Av. Fernando Cezar Coimbra, Barueri, São Paulo, entre os dias 27 e 30 de julho de 2009, com

os seguintes gerentes e diretor: Sr. Julio Pires, Gerente de Marketing, Sr. Eduardo Órfão, Controller, Sr. Everton Granero. Diretor Financeiro Grupo Granero.

\subsubsection{Como a organização desenvolve o Planejamento Estratégico}

Não há no momento uma definição de negócio clara a partir da missão e visão.

Não elabora diagnóstico como análise SWOT.

Analisa o ambiente com ações de curto prazo, como exemplo tem-se a substituição das filiais que não tinham uma boa performance por franquias com resultados favoráveis para a organização.

Outros fatores são analisados em parte, como a opção em atender classes sociais com alto poder aquisitivo, visando uma qualidade de atendimento superior.

Com relação aos fatores mais próximos da organização, analisam com mais ênfase os concorrentes diretos.

A análise de mercado não é tão profunda, limita-se a levantamentos de demanda, crescimento ou diminuição do mercado e para onde está migrando, como hábitos do consumidor em se mudar sem levar todas as coisas e sim comprar tudo novo.

Não há um gerenciamento direto dos recursos internos, porém percebe-se um apego muito grande dos colabores pela marca e o tempo que estão na organização, realizaram seus objetivos pessoais junto com a história da organização. 
As estratégias são fáceis de serem disseminadas pela sua simplicidade e imediatismo. A organização tem um posicionamento mais voltado para o público de alta renda com base na mudança residencial, comercial e guarda móveis, armazém.

Os objetivos são elaborados para o curto prazo, seis meses e médio prazo um ano. As estruturas organizacionais não são continuamente questionadas e dependem diretamente da posição dos sócios proprietários.

Existem alguns planos de ação, porém mais voltados à correção. Por exemplo, ações para reduzir o número de avarias nas mudanças com mais treinamento da mão de obra ou buscar fornecedores com mais qualidade na embalagem.

Os mecanismos de avaliação e controle são basicamente de indicadores financeiros básicos como, faturamento, lucro líquido, lucro operacional.

A organização é considerada de grande porte, seu faturamento anual esta por volta de $\mathrm{R} \$$ 13.000.000,00, com 2.000 funcionários diretos fora às franquias. $\mathrm{O}$ sistema de informação atual é da TUTVS.

\subsection{Análise e resultados sobre o processo de desenvolvimento do planejamento estratégico no modelo de empresa empreendedora}

A organização empreendedora tem fortes raízes no compartilhamento de valores e crenças dos sócios proprietários e dependem diretamente de suas aspirações e objetivos pessoais, fatores citados por Mooney (1947), Mintzberg (1979 e 2006) e Morgan (1996).

Caso a organização consiga crescer e se despontar no mercado o grande desafio é separar a gestão do fundador para uma gestão profissional e que consiga dar efetividade ao negócio, vale a colocação de Weber (1999) sobre o grau de burocracia e em que grau ela deve ser admitida. Pelos levantamentos e comparação entre as organizações pesquisadas percebe-se que muitas vezes não é só a figura do dono ou sócio proprietário, funcionários que participaram da fundação e crescimento da empresa trazem consigo culturas e crenças que podem dificultar adaptações para cenários não estáveis ou diferente daquele que estão acostumados. 
Termos ou ferramentas de gestão fora do contexto de aprendizado ou desenvolvimento do sócio proprietário e seus colaboradores mais antigos, não serão aceitos com facilidade gerando um grande desafio para os gestores mais novos que se desenvolveram num ambiente diferente. Fica mais difícil a tarefa da gerencia de ajustar e renovar os recursos e relacionamentos com o passar do tempo a fim de manter seu valor e posição competitiva, conceito defendido por Wernerfelt (1984), Rumelt (1984), Dierickx e Coll (1989) e Peteraf (1993). A palavra estratégia pode parecer algo que não pertence ao cotidiano destas organizações, porém ela existe em prazo, amplitude e risco diferentes.

Os prazos são mais curtos, difíceis passarem de dois anos. A amplitude restrita muitas vezes as regiões de atuação da organização e o risco muito voltado à tentativa e erro, não são elaboradas análises muito complexas ou quase nenhuma, depende da experiência e disponibilidade a correr risco do sócio proprietário no momento da decisão. De certa forma são desprezadas as análises defendidas por Smith e Chistensen (1951), Porter (1980), Ohmae (1985), Ansoff (2001) e Barney e Hesterly (2008).

Não foram observadas interferências das variáveis moderadoras.

A proposição P1 se confirma deixando claro que organizações tipo empreendedora tendem a visões de curto prazo ou sem o desenvolvimento do planejamento visando mais ações táticas de curto ou médio prazo.

\subsection{Owens-IIIinois do Brasil embalagens de vidro}

A história da empresa foi retirada do site da organização (O-I, 2009).

\subsubsection{Apresentação da empresa}

Em 1917, a O-I foi fundada no Rio de Janeiro pelos engenheiros, Olavo Egydio de Souza Aranha Jr e Alberto Monteiro de Carvalho e Silva, com a razão social Companhia Industrial São Paulo e Rio - Cisper.

A Cisper tornou-se conhecida, em todo o mercado brasileiro, como a indústria mais avançada na produção de embalagens de vidro. Esta marca inovadora acentua-se em 1960, quando assina um contrato de assistência técnica com a Owens Illinois, com opção de compra, pela empresa americana. 
A Owens Illinois surgiu em 1929, com a fusão da Owens Bottle Company com Illinois Glass Company. Em 1962, a Owens Illinois adquiriu o controle acionário da Cisper, operação que ofereceu à empresa acesso as mais avançadas tecnologias de produção do vidro e permitiu ao Grupo Monteiro Aranha realizar maior diversificação dos seus investimentos

A O-I é a maior empresa fabricante de embalagens de vidro do mundo. De cada dois recipientes de vidro feitos no mundo possivelmente um será fabricado pela O-I, por suas subsidiárias e por seus licenciados. A empresa é o principal fabricante de embalagens de vidro em 19 dos 22 países onde compete no segmento e o único fabricante dos recipientes de vidro em oito destes países.

A indústria do vidro transformou-se, diversificou-se e chegou a uma fase de maturidade, onde a O-I está presente em mais de 50 países da América Latina, Europa, América no Norte, Ásia e Oceania.

No Brasil a O-I tem 90 anos, com a marca CISPER, e é formada por quatro fábricas, que produzem mais de 500 itens para diversos segmentos, incluindo embalagens e utilidades.

\section{Caracterização no modelo, análises e considerações}

A organização ainda rotiniza as tarefas e possibilita controle por meio de regulamentos. $\mathrm{O}$ poder está dividido entre a alta gerencia e os técnicos especializados. A O-I é caracterizada por tamanho, trabalho repetitivo e ambiente estável. Até pouco tempo atrás o índice de performance organizacional mais importante era o pack-to-melt, ou uma relação do que entrava na fábrica como matéria prima para ser fundida e o que saia como embalagem. Hoje o conceito de pack-to-melt vem mudando para vender valor nas embalagens, porém o processo produtivo não é esquecido. Outro fator importante é o direcionamento da organização para projetos, como novos negócios e redução de custos. Existe um equilíbrio entre projetos para novos negócios e projetos para redução de custos, ou uma tendência da organização se tornar um híbrido entre máquina e inovadora, mas a predominância é para uma organização tipo máquina. 


\subsubsection{Dados Coletados}

As entrevistas foram realizadas nos escritórios da fábrica na Av. Olavo Egídio de Souza Aranha $n^{\circ}$ 2270, São Paulo, entre os dias 19 e 21 de outubro de 2009, com os seguintes gerentes e diretor: Sr. Leandro Pignataro, Gerente Comercial, Sr. Reinaldo Kuhl Gerente de Novos Negócios, Sr. Rildo Lima, Diretor de Marketing.

\subsubsection{Como a organização desenvolve o Planejamento Estratégico}

A organização tem uma definição clara a partir da missão e visão, porém esta missão é da matriz e cada região tem sua definição de acordo com as características das unidades estratégicas de negócio.

Uma ferramenta importante para a disseminação das estratégias regionais é o BSC. Sua estrutura atual já contempla uma série de analises voltadas à elaboração do diagnóstico.

A organização analisa todos os fatores do ambiente, e atualmente tenta entender melhor o ajuste de todas as cadeias produtivas com ferramentas denominadas customer back expertise e consumer back expertise, ou entendimento do comportamento dos principais fornecedores e clientes.

A organização também não deixa de realizar uma boa análise dos concorrentes diretos e analisa o dinamismo do mercado por segmento devido às várias aplicações dos seus produtos. Como trabalha com grandes clientes tem analises individuais.

O termo competência essencial não é claro para os entrevistados, porém a organização tem suas vantagens competitivas voltadas principalmente a projetos pontuais na fábrica, em vendas, na logística e outros.

As estratégias são compreendidas, porém pelo porte da empresa não é fácil disseminá-las. Os entrevistados enfatizam a importância do BSC nesta disseminação, mas não é tão simples.

O posicionamento está direcionado para diferenciação e foco em segmentos específicos. Os objetivos de curto prazo são definidos para o próximo ano, médio prazo de um a três anos e o longo prazo de três a cinco anos.

As estruturas organizacionais não são continuamente alteradas, e os planos de ação derivam do BSC. 
Os mecanismos de avaliação e controle são na sua maioria gerados pelo PTM ou pack-tomelt, BSC, normas ISO, e um aplicativo denominado Risk Management.

A organização é considerada de grande porte, seu faturamento mundial anual está por volta de $\mathrm{R}$ \$ 6.700.000.000,00, com 1.100 funcionários diretos no Brasil. O sistema de informação está migrando para o SAP. A organização utiliza o planejamento há mais de cinco anos.

\subsection{EMBRAER Empresa Brasileira de Aeronáutica S.A.}

Histórico fornecido pelos entrevistados a partir do relatório anual de 2008.

\subsubsection{Apresentação da empresa}

A Embraer, Empresa Brasileira de Aeronáutica S.A. é a terceira maior fabricante de aviões do mundo, atrás da Boieng e Airbus, posição alcançada graças à busca permanente pela inovação e pela plena satisfação de seus clientes.

Com mais de 38 anos de experiência em projeto, fabricação, comercialização e pós-venda, a empresa já produziu cerca de 4.900 aviões, que hoje operam em mais de 70 países, nos cinco continentes. A Embraer tem uma base global de clientes e importantes parceiros de renome mundial, o que resulta em uma significativa participação no mercado.

A Embraer foi a maior empresa exportadora brasileira entre os anos de 1999 e 2001, e foi a segunda maior empresa exportadora nos anos de 2002, 2003 e 2004. Atualmente sua força de trabalho totaliza mais de 23.878 empregados, $88,2 \%$ baseados no Brasil e contribui para a geração de mais de 5.000 empregos indiretos.

A Embraer continua a liderar o setor com suas inovadoras linhas de jatos regionais comerciais. Mais de 1000 ERJ foram produzidos desde 1996 e entregues a mais de 37 companhias aéreas em 24 países. Oferecendo um alto índice de comunalidade entre os membros da família, os ERJ 135, ERJ 140 e ERJ 145, com disponibilidade para 37, 44 e 50 passageiros respectivamente, oferecem versatilidade única para as empresas moldarem a capacidade das aeronaves com o tamanho do mercado. 
O negócio da Embraer é gerar valor para seus acionistas, através da plena satisfação de seus clientes do mercado aeronáutico global. Por geração de valor entende-se a maximização do valor da Empresa e a garantia de sua perpetuidade, com integridade de comportamento e consciência social e ambiental.

A Embraer investe em tecnologia direcionada à implementação de tecnologias de ponta que agregam valor, seja na engenharia, manufatura ou como parte de seus produtos. A assimilação dessas novas tecnologias chega aos fornecedores brasileiros, além de existir cooperações com instituições acadêmicas e de pesquisa.

\section{Caracterização no modelo, análises e considerações}

A organização rotiniza as tarefas e possibilita a gestão por meio de processos e busca otimizar estes processos. O poder está dividido entre a alta gerencia e os técnicos especializados, existem as áreas funcionais, mas também tem as áreas de projetos. Estas áreas têm seus planos de ação com resultados esperados e orçamentos, assim como, metas especificas para alcançar objetivos específicos. A EMBRAER é caracterizada por tamanho, trabalho repetitivo e ambiente relativamente estável.

A EMBRAER se caracteriza com uma predominância para organização tipo máquina.

\subsubsection{Dados coletados}

O primeiro contato foi em treze de Agosto de 2009, com as entrevistas finalizadas somente em 29 de outubro de 2009, nos escritórios da fábrica na Av. Brigadeiro Faria Lima, n 2170, São José dos Campos, SP, com os seguintes diretores: Engenheiro Luís Carlos Affonso, Vice Presidente Executivo da Aviação Executiva, Engenheiro Antônio Campello, Diretor de Planejamento Estratégico.

\subsubsection{Como a organização desenvolve o Planejamento Estratégico}

A definição do negócio é clara a partir da missão e visão, voltadas à consolidação da organização como uma das principais forças globais dos mercados aeronáuticos e de defesa, líder nos seus segmentos de atuação, reconhecida pelos níveis de excelência em sua atuação empresarial.

A organização elabora diagnóstico tipo SWOT, e considera o mercado de aviação um terreno já amplamente mapeado. A EMBRAER está bem preparada tecnologicamente e é detentora 
de pesquisa própria e patenteada gerando certa vantagem competitiva em relação aos concorrentes. Considera prioritariamente fatores como:

- Viabilidade e potencialidade dos mercados em que atua.

- Prospecção de produtos e serviços para novas regiões com potenciais de crescimento já auferidos.

- Análise criteriosa da atuação de seus principais competidores.

- Competências a serem ressaltadas e pontos fracos a serem aprimorados pela empresa.

- Oportunidades, desafios e riscos a serem enfrentados e superados.

A organização leva em consideração os fatores do ambiente para definição de estratégias, sendo que destas análises é que surgiu a idéia de atuar na aviação executiva, que hoje responde por quase $20 \%$ do faturamento da empresa. Dentre as variáveis mais importantes têm-se os fatores econômicos globais.

A aviação comercial tem uma correlação muito forte com o crescimento do PIB regional, e a aviação executiva com a elevação da rentabilidade corporativa. Regionalmente a organização avalia fatores sociais e culturais para o desenvolvimento de produtos personalizados.

As análises são realizadas por negócio nas distintas áreas de atuação atual da organização, ou seja, aviação comercial, aviação executiva e defesa.

A empresa trabalha com grandes contratos globais de fornecimento e está sujeita a capacidade de novos clientes em comprar. Os concorrentes diretos são analisados continuamente e também analisa o dinamismo do mercado.

Os recursos internos são continuamente gerenciados, sendo os valores da EMBRAER definidos a partir da participação de todos os empregados em um amplo processo de mapeamento e construção da cultura corporativa. Todos os empregados levam esses valores consigo no verso do seu crachá de identificação, em gesto de apoio, adesão e compromisso. Os valores que modelam as atitudes e unem as ações para assegurar a perpetuidade da empresa são:

- Nossa gente é o que nos faz voar.

- Existimos para servir nossos clientes. 
- Buscamos a excelência empresarial.

- Ousadia e inovação são a nossa marca.

- Atuação global é nossa fronteira.

- Construímos um futuro sustentável.

Para disseminar todos estes valores a EMBRAER tem um programa interno denominado P3E, ou seja, Programa de Excelência Empresarial EMBRAER. O programa abrange todas as áreas da companhia e foi a base para a superação de obstáculos e vem unindo todos os empregados em um grande trabalho de revisão de processos e busca de melhoria de resultados.

O P3E tem quatro pilares:

- O desenvolvimento da cultura organizacional da EMBRAER.

- O desenvolvimento das pessoas.

- A formação contínua de líderes e de suas habilidades de gestão

- A busca da excelência e eficiência em todos os processos da empresa.

Para viabilizar o programa os empregados se organizam em mais de quatrocentas células, que envolvem todas as unidades da EMBRAER. As iniciativas gerenciais do P3E também foram aplicadas a todas às áreas da cadeia produtiva e foram estruturadas com base na filosofia Lean Manufacturing, visando à otimização geral da arquitetura produtiva e à introdução das melhores práticas de manufatura utilizada no segmento aeronáutico mundial.

A organização identifica suas competências básicas, estratégias centrais e para novos negócios.

As estratégias são disseminadas e compreendidas a partir de um esforço de comunicação e relacionamento com as equipes de trabalho. Alguns programas são importantes nesta tarefa como: Conversa com a Direção, programa Boa Idea, programa Plano de Vôo.

A organização se posiciona como diferenciação e os objetivos são estabelecidos para o curto prazo, dois anos, médio prazo, dez anos e longo prazo uma visão estratégica para os próximos 20 anos. 
A organização está se transformando de uma estrutura fortemente funcional para uma estrutura focada nas Unidades de Negócio, com unidades de apoio centralizadas e planos de ação desenvolvidos e desdobrados em departamentos com metas e orçamentos.

Os controles de avaliação são internos com vários indicadores de desempenho, a EMBRAER implementa, desde 2002, processo estruturado e rígido de gestão de riscos em todos os níveis corporativos de seu negócio e que atendem amplamente às atuais exigências regulamentares do setor da aviação, seguindo padrões nacionais e globais.

A organização é considerada de grande porte, seu faturamento mundial anual está por volta de $\mathrm{R}$ \$ 11.000.000.000,00, com 17.000 funcionários diretos no Brasil. O sistema de informação é SAP com vários outros. A organização utiliza o planejamento desde 1994, porém com grau de importância nos últimos quatro anos.

\subsection{Análise e resultados sobre o processo de desenvolvimento do planejamento estratégico no modelo de empresa tipo máquina}

As organizações pesquisadas mostraram uma evolução dos indicadores de processos produtivos da máquina de Mooney (1947), Burns e Stalker (1961), Mintzberg (1979 e 2006) e Morgan (1996), para indicadores que de alguma forma possam medir o valor agregado de seus produtos e serviços. Percebe-se que aquela empresa nitidamente industrial está migrando para uma estrutura mais flexível adaptada para ambientes menos estáveis e com concorrentes que podem estar em qualquer lugar da terra seguindo a linha de pensamento de Dierickx e Cool (1989), Prahalad e Hamel (1990), Barney (1997) e Barney e Hesterly (2008).

As unidades de negócio apesar de receberem o direcionamento da matriz em âmbito global, Ackoff (1974), têm liberdade para desenvolverem produtos de acordo com a região e comportamento dos consumidores locais, respondendo melhor ao dinamismo do mercado local e concorrentes diretos e indiretos, análise de Porter (1980), Almeida (1997), Wrigth et al (2000) e Kluyver e Pearce (2007).

Apesar de ter uma característica que tende a uma organização híbrida, ou seja, uma predominância de máquina, porém com tendências a inovação, o ambiente tem um impacto forte neste tipo de empresa, mais uma vez Porter (1980). A visão de fora para dentro 
prevalece e as estratégias adotadas pendem para escala e escopo de Chandler (1990), ou atender muitos segmentos de mercado com poucas matérias primas.

Observa-se um embasamento forte na escola do Design de Mintzberg (2000), e apesar de gerenciar seus ativos intangíveis, reconhecer aqueles que são raros ou difíceis de imitar, os conceitos desenvolvidos principalmente por Prahalad e Hamel (1990), Barney (1997) e Barney e Hesterly (2008) não pareceram ser muito conhecidos entre os entrevistados.

As ferramentas de avaliação e controle são bem desenvolvidas, sendo o BSC de Kaplan e Norton (1997) a mais citada e utilizada, além dos indicadores próprios de cada indústria ou organização.

As organizações pesquisadas têm grande porte com sistemas de informação atual e integrado. Apesar de utilizarem o planejamento há muito tempo, sua importância é recente, não passa de cinco anos.

Não foram observadas interferências das variáveis moderadoras.

A proposição P2 não se confirma totalmente, pelas informações levantadas estas organizações apresentam uma característica Híbrida, ou seja, existe uma predominância para ênfase nos controles e trabalho repetitivo, porém pelo dinamismo de mercado este tipo de organização está se flexibilizando com áreas de projetos e estruturas que possam migrar da característica funcional.

\subsection{Fundação Armando Alvares Penteado}

O histórico da empresa e o Plano de Desenvolvimento Institucional Obrigatório foram fornecidos pelos entrevistados, porém com restrições para divulgação.

\subsubsection{Apresentação da empresa}

A Fundação Armando Alvares Penteado começou com um sonho do Conde Armando Alvares Penteado, compartilhado com sua esposa Dona Annie Alvares Penteado construir em São Paulo uma escola de arte.

Ao falecer, em 1947, ficou em seu testamento o delineamento da Fundação Armando Alvares Penteado, com a determinação de que fosse construída no local em que hoje ainda se encontra, uma "Eschola de Bellas Artes, compreendendo Pintura, Esculptura, Decoração e Architetura, com uma Pinacoteca”. 
Determinou, por outro lado, que a renda obtida com a venda das ações da Cia. Paulista de Estrada de Ferro e dos aluguéis de quatro prédios no Centro Velho de São Paulo seria dividida entre a Fundação e a Escola Politécnica da Universidade de São Paulo, renda esta que a Politécnica recebe até hoje.

O desenvolvimento da FAAP pode ser dividido em três períodos: o que antecedeu à morte de Annie Alvares Penteado em 1965, o período de implantação e consolidação, que ocorreu entre 1966 e 1990, e o período de renovação e preparação para o terceiro milênio, com a intenção de construir uma escola para o futuro, a partir de 1990.

Em 4 de janeiro de 1962, o governo estadual reconheceu a Fundação como entidade de utilidade pública. O mesmo reconhecimento foi realizado pelo governo federal em 1968, e pelo governo municipal em 1971.

O ingresso na área educacional deu-se com o curso de Licenciatura em Desenho e Artes Plásticas, reconhecido, pelo extinto Conselho Federal de Educação, em 1963.

Foi durante as décadas de 1960 e 1970 que foram criadas as Faculdades de Artes Plásticas, Comunicação, Engenharia, Administração e Economia.

A FAAP passou por uma reestruturação que a transformou em uma entidade com espírito inovador e empreendedor, sua grande marca ainda hoje.

Foi implantado um novo modelo administrativo, atualizado, moderno, para que pudesse sobreviver com autonomia, gerindo, equilibradamente, as receitas e os custos, possibilitando investimentos em recursos humanos, professores e funcionários mais qualificados, materiais, aquisição de equipamentos e reforma geral das instalações.

Como parte integrante da sua política de ação e da sua organização, a FAAP buscará consolidar, cada vez mais, seus vínculos com organizações sociais, culturais, artísticas, governamentais e empresariais para fortalecer o desenvolvimento das suas unidades encarando-as como importantíssimas vias de acesso ao conhecimento. Assim, aos poucos, as Faculdades estão acompanhando o surgimento de um novo modelo de integração da FAAP com as empresas e a sociedade, o que impulsionará o desenvolvimento do educando e facilitará a sua imediata inserção no universo profissional. 


\section{Caracterização no modelo, análises e considerações}

A FAAP têm na maioria dos seus colaboradores professores com treinamentos avançados, que apreciam a autonomia e exercem atividades que exigem habilidades técnicas. A maioria destes profissionais é independente e a demanda por seus serviços é elevada.

A Mantenedora emana as diretrizes amplas e cada escola tem liberdade de conduzir o planejamento pedagógico, linhas de pesquisa, formas de conduta docência e outros.

Os parâmetros de caráter orçamentário são enviados pela mantenedora e cada escola pode ser considerara como uma empresa relativamente autônoma como unidades de negócio.

Assim tem-se uma nítida caracterização de uma organização profissional.

\subsubsection{Dados Coletados}

As entrevistas foram realizadas no campus da R. Ceará no 3, São Paulo, entre os dias 19 e 28 de agosto de 2009, com os seguintes docentes: Prof. Henrique Vailati, Diretor da Faculdade de Administração, Prof. Dr. Tharcisio Bierrenbach de Souza Santos, Diretor do MBA e Prof. Walter Gomes da Cunha Filho Coordenador de Operações.

\subsubsection{Como a organização desenvolve o planejamento estratégico}

A organização tem sua definição de negócio clara a partir da missão e visão, inseridas no plano de desenvolvimento institucional obrigatório, e no momento tenta aprimorar a elaboração do diagnóstico. Um conselho diretivo junto com a mantenedora realiza sistematicamente o diagnóstico.

Os fatores do ambiente são constantemente levados em consideração, o fator econômico pode influenciar variações de fluxo de caixa, adimplência e inadimplência, demanda para o vestibular. Porém, as duas grandes linhas de análise se encontram nas variáveis culturais e sociais. A variável cultura tem um impacto importante pelo próprio posicionamento da organização, sempre foi muito voltada ao desenvolvimento e divulgação da cultura mundial.

A organização considera seus grandes fornecedores colégios de ensino médio de segmentos de mercado diferenciados com perfil de aluno oriundos das classes mais favorecidas. Outro 
fator importante é a chegada de grandes conglomerados internacionais de investimento adquirindo entidades de ensino superior e algumas fusões entre grupos de ensino.

Os concorrentes diretos são constantemente analisados, assim como dinamismo do mercado.

Os recursos internos são gerenciados e podem ser considerados como diferenciais da organização, a relação professor/ aluno, recuperação paralela ou trabalho com pais fazem parte destas competências. Outras foram relatadas pelos entrevistados que optaram por não divulgar.

As estratégias são fáceis de serem compreendidas e disseminadas, e o posicionamento da organização é claramente direcionado para diferenciação.

Os objetivos são estabelecidos para o curto prazo um ano devido principalmente ao vestibular, médio prazo de três anos até quatro anos, muito ligado às visitas do Ministério da Educação (MEC) que podem obrigar a revisão do PDI e o longo prazo superior a quatro anos, à média de ciclo de cada turma.

A organização vem sofrendo algumas reformulações internas nos últimos seis anos para melhorar rotinas e atendimento e principalmente se adequar à legislação do MEC pelo fato de não ser Universidade.

As unidades de negócio têm planos de ação para implementação das estratégias e para atingir os objetivos.

Os mecanismos de avaliação e controle são, CPA uma comissão interna de avaliação onde funcionários e professores realizam esta avaliação institucional, a avaliação feita pelos alunos a cada semestre da instituição para o corpo docente e a avaliação interna feita sistematicamente pelo MEC. Os entrevistados consideram o Plano de Desenvolvimento Institucional como algo parecido ao BSC adaptado para instituições de ensino.

A organização é considerada de grande porte, seu faturamento anual está por volta de R\$ 200.000.000,00, com 1.400 funcionários diretos. O sistema de informação para gestão acadêmica é feito pelo Lyceum e a gestão administrativa com banco de Dados base Oracle. A organização utiliza o planejamento há mais de dez anos. 


\subsection{Hospital Carlos Chagas}

Histórico fornecido pelos entrevistados e disponível no site da organização (HCC, 2009).

\subsubsection{Apresentação da empresa}

Fundado por sete médicos há quarenta e seis anos, o Hospital Carlos Chagas S/A, é um hospital da iniciativa privada, de prestação de serviços médicos a particulares e convênios. É um hospital geral, isto é, destinado ao atendimento de pacientes nas mais variadas especialidades médicas. Iniciou-se com um pronto socorro em dezembro de 1962, tendo este quatro leitos, passando para doze leitos em 1964, recebendo nesta data a denominação de Pronto Socorro e Maternidade Guarulhos Ltda. A direção desta entidade sempre visando aprimorar os serviços médicos que vinham prestando a população de Guarulhos, em meados de 1965 sentiu necessidade e também a possibilidade de construírem um hospital com maiores recursos, planejando desta forma um hospital com sessenta e dois leitos. Dois anos após, ou seja, 1967 fundaram o Hospital Pronto Socorro Maternidade de Guarulhos.

Em 1969, já com o $1^{\text {o }}$ andar construído, tendo vinte leitos e Centro Cirúrgico, passa a denominar-se Hospital Carlos Chagas, passando de Ltda. para S/A em 1973. A construção do $2^{\circ}$ andar terminou em meados de 1970, ampliando-se o número de leitos para sessenta e seis. Em 1985 houve uma expansão com a construção do $3^{\circ}$ e $4^{\circ}$ andares elevando o número de leitos para cento e setenta e quatro. Em 1996, nova expansão com a construção do $5^{\circ}$ andar. Com esta evolução gradativa do hospital, seus diretores destinaram os novos recursos gerados para a ampliação e melhoria dos serviços através da compra de equipamentos e instalação de novos serviços. A esta estrutura, foram agregando-se profissionais médicos das mais diversas especialidades e demais profissionais da área da saúde, bem como pessoal da administração e do serviço de apoio, que vem no decorrer desses anos, atuando na preservação do bem mais importante para todos, a saúde.

Hoje o Hospital Carlos Chagas S/A, conta com uma área de internação formada por apartamentos privativos e semi-privativos, uma Unidade de Terapia Intensiva Adulto, Infantil e Neonatal, totalmente equipada com aparelhos de última geração e assistida permanentemente por especialistas intensivistas. Dispões ainda de serviços de Medicina Diagnóstica , capacitada para a realização de diversos exames no diagnóstico e tratamento, 
além do serviço de tomografia computadorizada, ressonância nuclear magnética, Multi-slice, entre outros aparelhos de última geração.

\section{Caracterização no modelo, análises e considerações}

O Hospital Carlos Chagas tem na maioria dos seus colaboradores médicos com treinamentos avançados, que apreciam a autonomia e exercem atividades que exigem habilidades técnicas. A maioria destes profissionais é independente e a demanda por seus serviços é elevada.

Nos últimos quinze anos a organização passa por um processo de profissionalização que se iniciou com a ajuda do Prof. João Bosco Lodi da Fundação Getúlio Vargas.

Os profissionais médicos têm uma carga de atualização muito grande com cobrança e apoio da organização, porém hoje uma parte da administração já é gerida por especialistas de outras áreas como economistas, administradores, especialistas em marketing, jornalistas e outras funções, mesmo assim a predominância é por uma organização tipo profissional.

\subsubsection{Dados coletados}

As entrevistas foram realizadas no hospital Carlos Chagas, na Rua Barão de Mauá $\mathrm{n}^{\circ}$ 100, Guarulhos, São Paulo, entre os dias 23 e 25de setembro de 2009, com os seguintes médicos e administradores: Dr. Antonio Carlos Garcia, Conselho de administração, Sr. Carlos Américo Rente, Superintendente, Sr. Pedro Rodrigues, Administrador Hospitalar.

\subsubsection{Como a organização desenvolve o planejamento estratégico}

A definição do negócio é clara a partir da Missão e Visão da empresa. Complementando o histórico, o grupo Carlos Chagas é composto de cinco empresas dentro do negócio saúde: dois hospitais, uma operadora de planos de saúde, um dental center e uma organização de medicina ocupacional. Optou-se por analisar somente o hospital Carlos Chagas.

A organização levanta informações a partir de uma controladoria financeira e de qualidade, além do Serviço de atendimento ao Consumidor, SAC. Dentro do hospital tem a Organização Nacional de Saúde (ONA), creditado no nível dois, que é chamado nível pleno, e existe uma auditoria independente. 
A organização acompanha todos os movimentos da cidade de Guarulhos, pela proximidade com São Paulo anteriormente chegou-se a perder muitos pacientes. Hoje pelo desenvolvimento da cidade e fatores que dificultam o acesso a São Paulo, pode-se dizer que a organização tende a crescer junto com a cidade.

A organização no momento tem acompanhado os avanços do setor que acontecem em grandes centros como São Paulo e pode competir de igual para igual.

Um fato interessante da entrevista foi à preocupação do Dr. Antonio em alegar que é médico, mas aprendeu administração lendo muito e acompanhando os administradores da organização, motivos que o levaram a presidência da organização por sete anos.

A organização vem tentando diminuir o poder de alguns fornecedores com o desenvolvimento de novos fornecedores, porém ainda sofre em alguns produtos como oxigênio, soro e outros serviços. A empresa procura ter sempre dois ou três fornecedores para cada tipo de produto. As compras são anuais e negociadas sempre com mais dois fornecedores. Com a obtenção da ONA todos os fornecedores devem ter qualidade assegurada, principalmente em organizações que lidam com vidas humanas.

Existe um fator político legal que interfere diretamente no negócio, o governo é quem define os reajustes de preço das operadoras de planos de saúde que por sua vez são os grandes clientes dos hospitais, ou seja, todos estão sofrendo grandes pressões que podem impactar na rentabilidade do negócio.

Além do controle de preços existe também o controle dos procedimentos que também podem impactar diretamente nos custos. A tendência é a minimização de operadoras e seguradoras de saúde, assim como de hospitais.

A organização tem no momento quatro concorrentes diretos, sendo que um deles com grande potencial. No momento devido ao seu controle de custos muito eficiente tem se mantido na liderança na região de Guarulhos.

O dinamismo do mercado é analisado continuamente.

Os recursos internos raros estão focados na experiência de alguns profissionais com larga experiência na empresa, porém de acordo com os entrevistados esta dependência pode em algum momento comprometer a performance da organização. 
As estratégias da organização tornaram-se mais fáceis de serem disseminadas e compreendidas a partir de um esforço de comunicação interna que está sendo realizado com o auxílio de uma profissional.

O hospital se posiciona como uma organização diferenciada e os objetivos de curto prazo são para no máximo um ano, o médio prazo três anos e o longo prazo cinco anos.

As estruturas organizacionais não são continuamente questionadas e os planos de ação são definidos por setores. Dentro de um hospital existem vários setores, porém as metas são estabelecidas na alta gerencia.

A organização tem controles financeiros que são emitidos todos os dias, com despesas e receitas de todos os setores. Porém existia um excesso de controles que muitas vezes não estavam relacionados principalmente a rentabilidade e performance do negócio, foi necessária uma revisão para saber o que realmente interessa.

A organização é considerada de grande porte, seu faturamento anual está por volta de $\mathrm{R} \$$ 245.000.000,00, com 1.430 funcionários diretos. O sistema de informação é próprio com banco de Dados base Oracle. A organização utiliza o planejamento há mais de cinco anos.

\subsection{Análise e resultados sobre o processo de desenvolvimento do planejamento estratégico no modelo de empresa tipo profissional}

Um fato comum entre as organizações pesquisadas é a dependência de profissionais com alto grau de treinamento e uma certa autonomia nas suas atividades, característica deste tipo de organização defendida por Mintzberg (2000) e Morgan (1996). Mesmo com a profissionalização de algumas áreas fica difícil imaginar uma faculdade sem professores ou um hospital sem médicos.

As entrevistas evidenciaram a dependência deste tipo de organização, ou pelo menos as pesquisadas por regulamentações governamentais com forte impacto no desenvolvimento e rentabilidade das empresas, ou como se adapta aos desafios do ambiente, conceito colocado por Hampton (1986).

A Faculdade pesquisada disponibilizou o plano de desenvolvimento institucional e como já existe esta determinação por parte do órgão regulamentado, ou seja, o MEC optou-se por não sugerir outro modelo e fica no trabalho particularidades e características para este tipo de 
empresa e a preocupação em acompanhar este fator político-legal. Não se pode esquecer a importância da organização em criar vínculos com organizações sociais, culturais, artísticas, governamentais e empresariais para fortalecer o desenvolvimento das suas unidades encarando-as como importantíssimas vias de acesso ao conhecimento, evidenciado no trabalho de Harrison (2005).

Assim para organizações profissionais o foco neste trabalho será para hospitais. De acordo com Organização Pan-Americana de Saúde (OPAS, 2009), hospitais são todos os estabelecimentos com pelo menos cinco leitos, para internação de pacientes, que garantem um atendimento básico de diagnóstico e tratamento, com equipe clínica organizada e com prova de admissão e assistência permanente prestada por médicos. Além disso, considera-se a existência de serviço de enfermagem e atendimento terapêutico direto ao paciente, durante 24 horas, com a disponibilidade de serviços de laboratório e radiologia, serviço de cirurgia e/ ou parto, bem como registros médicos organizados para a rápida observação e acompanhamento dos casos. Assim os hospitais são organizações complexas que, como qualquer empresa precisa lidar com aspectos econômicos, sociais e ambientais, com a característica própria onde seu principal negócio é cuidar da saúde das pessoas. Este conjunto de atividades engloba lidar, além de pessoas, com tecnologias, governos, sociedade, aspectos críticos ambientais, tudo isso com a preocupação de gerir bem seus recursos e, no caso de hospitais privados, darem lucro.

De forma simplificada, os hospitais devem cuidar de duas saúdes: a dos pacientes, e a do próprio hospital, o que nem sempre é fácil de ser conseguido. Mas a responsabilidade funcional dos profissionais da medicina será mais bem atendida se forem oferecidos os recursos materiais necessários para o exercício de sua profissão. Dosar esses recursos de forma a garantir esse exercício e a continuidade dos bons serviços do conjunto da operação é a magia, no bom sentido, da gestão hospitalar.

Os principais públicos interessados dos hospitais privados são: proprietários, conselho, representante dos associados contribuintes que podem contratar e demitir executivos profissionais, comunidade mais próxima, fornecedores, pacientes e familiares, funcionários, médicos, universidades, governo, operadores de saúde e sociedade, no sentido mais amplo.

Não foram observadas interferências das variáveis moderadoras.

Diante do exposto a Proposição P3 se confirma, ou pelas pesquisas levantadas percebe-se uma forte dependência das organizações profissionais dos públicos interessados. 


\subsection{Vivo telefonia celular}

O histórico da empresa foi retirado do site da organização (VIVO, 2009).

\subsubsection{Apresentação da empresa}

A Vivo, controlada pelos grupos Portugal Telecom e Telefônica, é a operadora de telefonia celular que oferece a melhor qualidade de ligação, de acordo com os indicadores da Agência Nacional de Telecomunicações, Anatel. Entre seus diferenciais competitivos destacam-se: a constante busca na excelência da prestação de serviço, com foco na qualidade em todos os pontos de contato do cliente com a operadora, os serviços de transmissão de dados em banda larga baseada na rede de terceira geração e o amplo portfólio de produtos e serviços. Além disso, a empresa cumpre com seu papel de ser um agente de transformação social. Para isso, busca realizar suas ações sempre com o objetivo de atender o maior número de pessoas.

Sua missão está relacionada à, ser a melhor opção em comunicação com mobilidade, e sua visão de futuro, ser a empresa líder e inovadora em soluções móveis de comunicação, informação e entretenimento. Comprometida na geração de valor aos clientes, colaboradores, acionistas e comunidade.

A marca Vivo foi lançada em 2003 para representar a maior comunidade de clientes do Brasil. A proposta da marca é oferecer produtos e serviços de comunicação móvel, trazendo inovações e vantagens para tornar o dia-a-dia de seus clientes mais fácil e divertido. A marca Vivo, como o próprio nome diz, representa vida, energia, alegria e uma atitude positiva. $\mathrm{O}$ ícone que representa a marca traduz a postura convidativa e os valores da Vivo: proximidade, transparência, simplicidade, brasilidade e acessibilidade.

O ícone representa o companheiro que torna o dia-a-dia mais fácil e divertido. Seu dinamismo e seu aspecto visual, com diversas cores e posições, representam a diversidade da comunidade de clientes da Vivo. Uma comunidade brasileira que inclui a todos, porque a Vivo é para todo mundo! O ícone também personifica a Vivo, a tecnologia e os serviços que oferece, tornandoa mais tangível e humana. A Vivo é a maior operadora móvel do Brasil no momento, com mais de $30 \%$ de participação de mercado e quarenta e oito milhões de clientes. 


\section{Caracterização no modelo, análises e considerações}

A inovação faz parte da Visão da empresa com forte desenvolvimento em pesquisa e os aspectos tecnológicos por si só não são os principais, mas a decorrência deles. A organização entende que ser inovadora é facilitar a vida das pessoas, tem apenas seis anos e estão em constante renovação sempre visando à simplicidade de utilização dos seus serviços para o usuário final.

Embora os processos sejam importantes para o funcionamento da organização, pelos entrevistados não está na sua alma, o que prevalece é a inovação.

Assim a predominância é por uma característica inovadora.

\subsubsection{Dados coletados}

As entrevistas foram realizadas no escritório da Vivo na Av. Dr. Chucri Zaidan no 860, São Paulo, entre os dias 2 e 7 de outubro de 2009, com os gerentes e diretor: Sr. Antonio Carlos Cipriano, Diretor Regional São Paulo, Sr. Felipe Campos, Gerente de Planejamento Administração de Vendas, Sr. Rene Ruszki, Gerente de Operações de Varejo.

\subsubsection{Como a organização desenvolve o Planejamento Estratégico}

A organização tem sua definição de negócio absolutamente clara a partir da Missão e Visão, e é um dos elementos mais cobrados pelo presidente para que haja estes atributos.

A organização tem um coordenador de Planejamento Estratégico que orienta as áreas e nasce de premissas que os acionistas colocam levando em consideração um diagnóstico do mercado brasileiro, os concorrentes diretos mais um histórico da operação dos anos anteriores e os objetivos que pretendem alcançar. Tudo isto como uma grande orquestração e que demora em média de três a quatro meses.

A organização é olhada no ponto de vista quantitativo e qualitativo, ou pessoas mais resultados e atualmente visando a sustentabilidade. A Vivo recolheu mais de trinta e oito mil baterias para dar um uso correto e todas as lojas têm postos para depósito de baterias. Ou seja um dos fatores importantes de análise do ambiente é o fator ecológico. 
Outra ferramenta importante para análise do ambiente é o Geomarketing, que determina as áreas com carências de cobertura, falta de capilaridade de vendas, áreas com gestão deficiente, áreas onde os concorrentes diretos estão melhores ou a organização se sobressai. A ferramenta do Geomarketing é cruzada com outras métricas e os objetivos estabelecidos para melhor análise.

A Vivo tinha, anteriormente, uma briga com os quatro maiores fornecedores, Nokia, Sansung, Motorola e LG, numa ação inovadora trouxe para dentro do negócio os fornecedores indagando-os sobre como eles gostariam de participar mediante os objetivos da organização. Esta parceria fez com que vários lançamentos tivessem sua exclusividade com a Vivo e a briga passou a ser de como cada fornecedor pode contribuir mais com o resultado da organização e não como cada um pode diminuir seu custo com a Vivo.

O mercado em telecomunicações é muito dinâmico, a tecnologia muda constantemente e toda indústria está na fase de melhorar sua cobertura em $3^{\mathrm{a}}$ Geração e já se preocupa com a $4^{\mathrm{a}}$ Geração, com bandas mais velozes que as atuais.

A organização gerencia os recursos internos com a ajuda do BSC e mais quatro avaliações formais de feedback para cada um dos colaboradores, para que os mesmos entendam como contribuíram de forma diferente para os resultados da organização que no decorrer do tempo pode formar um banco de dados identificando height flyers, ou pessoas com talento diferenciado e que gerem inovação para o negócio. Estas pessoas são recompensadas semestralmente e a organização é permeável a entender como cada um contribui e se desenvolve desde projetos simples até absolutamente inovadores no ganho de escala. Existe também um programa de trainee que é um dos mais disputados no Brasil, que coloca dentro da organização trinta pessoas todos os anos com diferentes experiências para questionar e opinar em diferentes áreas da organização.

A organização nos seus sistemas de avaliação internos sempre pergunta aos colaboradores:

- Você confia nas decisões estratégicas dos líderes da companhia.

- Você compreende, entende e pode discutir estas estratégias.

- O seu gestor está aberto a discutir estas estratégias. 
A organização prima, nas palavras do seu presidente Sr. Roberto Lima, pelo empenho em orientar as pessoas para que elas saibam para onde a Vivo quer ir e assim fica mais fácil de conduzi-las.

A organização posiciona-se com uma estratégia voltada para diferenciação, até porque é percebida como a operadora mais cara do mercado, inovadora e de qualidade.

Pela característica da organização e dinamismo do mercado os objetivos de curto prazo são estabelecidos trimestralmente, o médio prazo semestral e longo prazo um ano.

A estrutura organizacional muda toda hora e a Vivo trabalha num conceito de estrutura matricial. Os planos de ação são integrados entre as áreas com dependências muito forte devido principalmente à estrutura matricial.

A organização utiliza como mecanismo de controle o BSC.

A organização é considerada de grande porte, seu faturamento anual está por volta de $\mathrm{R} \$$ 15.000.000.000,00, com 10.000 funcionários diretos. O sistema de informação é SAP. A organização utiliza o planejamento há mais de seis anos.

\subsection{F/Nazca Saatchi \& Saatchi agência de publicidade}

O histórico da organização foi adaptado e fornecido pelos entrevistados.

\subsubsection{Apresentação da empresa}

A F/Nazca nasceu em 1994 e faz parte da rede internacional de agências Saatchi \& Saatchi, pertencente ao Publicis Group, que possui cerca de 7.000 funcionários trabalhando em 143 escritórios espalhados por 83 países.

Em 2000 a agência recebeu seu primeiro título internacional, o de Agência do Ano para as Américas, concedido pela publicação norte-americana Advertising Age. No ano anterior, em 1999, recebeu o principal prêmio da propaganda brasileira, o Prêmio Caboré de Agência do Ano.

Já em 2001 conquistou seu maior título, o de Agência do Ano no Festival de Cannes, considerado o Oscar da propaganda, por ter sido a mais premiada do mundo naquele evento, 
com oito Leões, três bronzes em filmes, dois ouros em mídia impressa e um ouro e dois bronzes em Internet.

Por cinco anos consecutivos, de 2003 a 2007, a F/Nazca recebeu o título de Agência do Ano no Festival Brasileiro de Publicidade promovido pela Associação Brasileira de Propaganda.

A agência é responsável por cases de sucesso e slogans como 'Desce redondo', para a Skol, 'Nem parece banco', para o Unibanco, e 'O melhor plano de saúde é viver. O segundo melhor é Unimed', para a Unimed. Personagens como as formiguinhas da Philco e a tartaruga da Brahma também foram criações da F/Nazca.

\section{Caracterização no modelo, análises e considerações}

A organização tem uma vocação criativa muito grande, com ênfase na pesquisa principalmente para clientes. Considera-se inovadora por ser a primeira agência a ter uma área voltada a Internet há mais de 10 anos, totalmente flexível sem estrutura fixa ou até salas individualizadas. Não existe hierarquia rígida e a organização dá preferência para pessoas que tragam novos conhecimentos.

Dentro destas características pode-se enquadrar como uma organização tipicamente inovadora.

\subsubsection{Dados coletados}

As entrevistas foram realizadas no escritório da F/Nazca na Av. República do Líbano nº 253, São Paulo, entre os dias 14 e 15 de outubro de 2009, com os diretores: Sr. Fernand Alphen, Diretor de Planejamento, Sr. André Gustavo Souza, Diretor de Atendimento, Srta. Eliana Bueno, Diretora de Mídia.

\subsubsection{Como a organização desenvolve o planejamento estratégico}

A organização tem uma intuição sobre a missão e visão, mas não está escrito em lugar nenhum.

O tempo todo está de olho nos concorrentes, para verificar como as agências estão atendendo seus clientes e qual o olhar que elas trazem para a publicidade. Por ser uma agência internacional ela é demandadora de novidades que vem de fora e fornecedora de novidades estudadas no Brasil. 
O fator econômico é importante, mas nunca fez com que a organização redefinisse sua vocação. O que realmente faz com que a organização possa rever sua vocação é à busca do novo, como fazer diferente.

No último encontro do MaxiMídia o presidente da empresa Sr. Fábio Fernandes debateu sobre a crise como uma oportunidade para as agências se diferenciarem.

A organização não sofre pressão dos grandes fornecedores, é mais uma relação de parceria e ao longo dos anos foi deixando de depender de poucos clientes.

O que traz algum transtorno para a organização é o que os entrevistados chamam de concorrente especializado, ou consultorias de comunicação que podem interferir no processo de criação e posicionamento dos clientes, assim como aquele consultor que foi contratado para outras áreas mas dá suas sugestões na comunicação. Outro fator importante são os concorrentes diretos que se vendem por qualquer preço. Existe também a ação de concorrentes complementares, mas na maioria das vezes podem até ajudar.

A agência na grande maioria dos clientes está entre as primeiras opções e tem um posicionamento para diferenciação.

Não são estabelecidos objetivos para o curto, médio e longo prazo. As estruturas organizacionais são questionadas o tempo inteiro.

Não há planos de ação formalizados e os mecanismos de controle e avaliação não foram revelados pelos entrevistados.

A organização é considerada de grande porte, seu faturamento anual está por volta de $\mathrm{R} \$$ 1.000.000.000,00, com 300 funcionários diretos. Não foi informado o sistema de informação e como não há planejamento formal se desconhece o tempo de utilização. 


\subsection{Análise e resultados sobre o processo de desenvolvimento do planejamento estratégico no modelo de empresa tipo inovadora}

As pesquisas mostram o dinamismo e facilidade de adaptação deste tipo de organização, assim como a busca pelo novo ou ajuste tecnológico.

São organizações que se moldam de acordo com o mercado ou estão continuamente buscando se diferenciar dos concorrentes, ou até criar novos conceitos para utilização de produtos e serviços. Cabe a colocação de Schumpeter (1942) onde as organizações podem ser inovadoras e eficientes, e numa economia competitiva apresentar novas combinações eliminando o velho.

As pessoas são os ativos mais valiosos para a organização inovadora e apesar dos entrevistados não citarem os termos desenvolvidos no referencial teórico por Prahalad e Bettis (1986), Prahalad e Hamel (1990), Mahoney e Pandian (1992), Peteraf (1993), Collis e Montgomery (1995), Foss (1997) e Barney e Hesterly (2008), fica claro todo seu gerenciamento e a busca do talento criativo.

O mais curioso, principalmente na pesquisa realizada com a agência de publicidade é a fuga do formal, do engessado e do burocrático. Os colaboradores entendem a razão de ser da empresa, mas nada é imposto ou formalmente divulgado, não há objetivos explícitos, mas a busca por resultados é constante e o ajuste inevitável.

A estrutura matricial citada por Vasconcellos e Hemseley (1997), Aaker (2001) e Certo et al (2005), impera e a facilidade de comunicação e integração entre as equipes de projeto são os grandes desafios.

Não foram observadas interferências das variáveis moderadoras.

A proposição $\mathrm{P} 4$ se confirma apesar das organizações entrevistadas não citarem os termos do referencial teórico como, competências essenciais ou teorias da RBV. 


\section{CONSIDERAÇÕES FINAIS}

O tema tratado neste trabalho sempre será um grande desafio para qualquer organização, pesquisador ou gestor que de alguma forma desejar permanecer em um ambiente complexo e instável.

Planejamento estratégico e administração estratégica têm a ver com o futuro de uma organização e seu desenvolvimento. O primeiro constrói a condução, e o segundo como será conduzida. A reflexão antecede a ação, e está relacionada ao sonho de se chegar a algum lugar como se espera, mas sem a ação corre-se o risco de ficar somente sonhando. A ação sem reflexão pode ser um pesadelo, não se chegar a lugar nenhum ou se chegar com um esforço que talvez não compense.

Lidar com futuro e mudança pode fugir do controle, o que cria um grau de incerteza e pode inibir qualquer tentativa de prevê-lo ou conduzi-lo.

A estratégia está relacionada à mudança, a direcionar algo de um ponto ao outro, deve considerar a situação existente e projetar como e quando a mudança deverá ocorrer, quem é o responsável por esta mudança, quais os recursos necessários e como o cenário vai se apresentar e impactar. Resumindo, não é fácil, o "samba do analista doido", no ano de 2008, serviu para mostrar a fragilidade dos modelos de previsão do futuro usados por economistas, analistas ou qualquer gestor que tentou prever aquele cenário.

Tem-se a partir de todo referencial teórico levantado uma base para se entender as visões que vigoram até o momento sobre o processo de desenvolvimento do planejamento estratégico, e como os diversos autores tratam das etapas, passos e análises.

As configurações organizacionais apresentadas podem ajudar pesquisadores e gestores a entenderem melhor sua organização e como lidar com estas particularidades.

A pesquisa levantada identifica e analisa de uma forma inédita as relações do planejamento estratégico em cada modelo organizacional escolhido, assim como se tem a seguir uma proposta de estrutura diferente para o desenvolvimento desse planejamento. Um fato importante é que a maioria das organizações entrevistadas usa o planejamento em média há cinco anos. 
Para empresas que se caracterizam como empreendedoras no processo de desenvolvimento do planejamento estratégico inicialmente deve-se contar com a participação direta do sócioproprietário e seus colaboradores mais próximos.

Como existe certo receio à terminologia utilizada na academia, uma sugestão pode ser trocar o termo planejamento estratégico por plano de crescimento organizacional. Conceitos como missão e visão, para facilitar o entendimento e adaptá-lo à realidade pode ser trocado por uma definição do negócio, que deixe claro para o sócio-proprietário e seus seguidores diretos:

- Que necessidade do mercado a organização atende (O que?).

- Para quem direcionamos nossos esforços (Para quem?).

- Com que conhecimento ou qual a tecnologia (Como?).

Os levantamentos ou análise do ambiente, posicionamento de mercado, objetivos, planos de ação e avaliação e controle foram sugeridos pelos levantamentos da pesquisa e adaptados para melhores ajustes à organização tipo empreendedora de acordo com a estrutura proposta na Figura 5. 


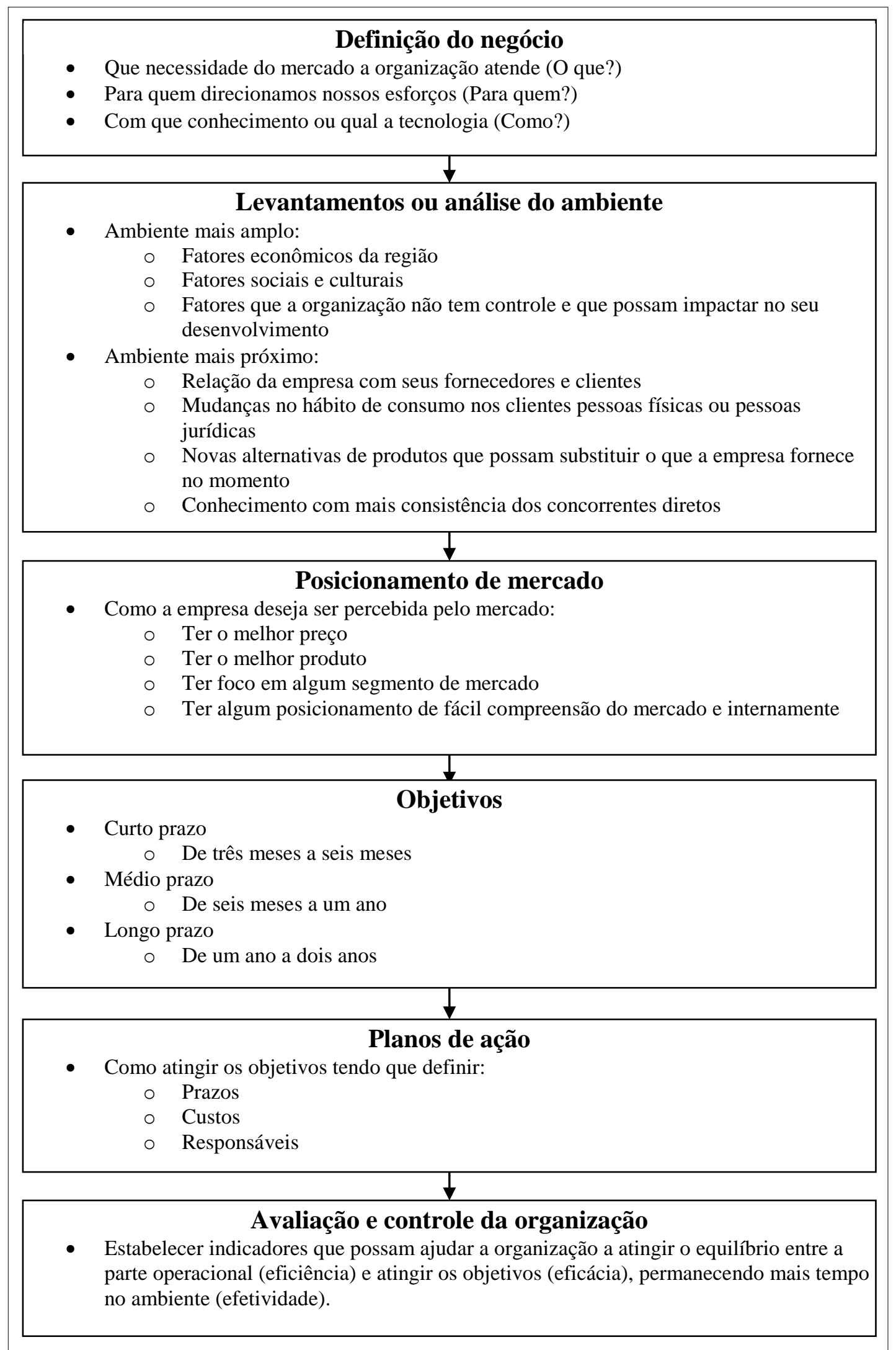

Figura 5 - Sugestão para o desenvolvimento do Planejamento Estratégico para empresas tipo empreendedora 
Para empresas tipo máquina a sugestão é um planejamento voltado às unidades de negócio, já que as pesquisas mostraram que estas Unidades apesar de responderem diretamente para uma matriz elas têm certa autonomia com mercados e concorrentes muitas vezes distintos.

Os fatores do ambiente devem levar em consideração características globais e regionais e passa a ser importante este tipo de organização entender toda sua cadeia produtiva. Como colocado por uma das organizações entrevistadas projetos que visem o conhecimento do customer back expertise e consumer back expertise são passos fundamentais para perpetuidade no mercado.

O trinômio preço, prazo e qualidade devem ser revistos continuamente para melhor posicionamento de mercado e os objetivos, diferentes de outras tipologias podem ser definidos com prazos maiores.

Os planos de ação podem ser definidos por área ou funcionais, porém deve-se levar em consideração que este tipo de organização tende a um modelo híbrido podendo gerar objetivos por projetos.

Para avaliação e controle a organização pode optar por modelos já desenvolvidos e consagrados como BSC ou modelos que de alguma forma contemplem a Responsabilidade Social Empresarial.

Estrutura sugerida de acordo com a Figura 6. 


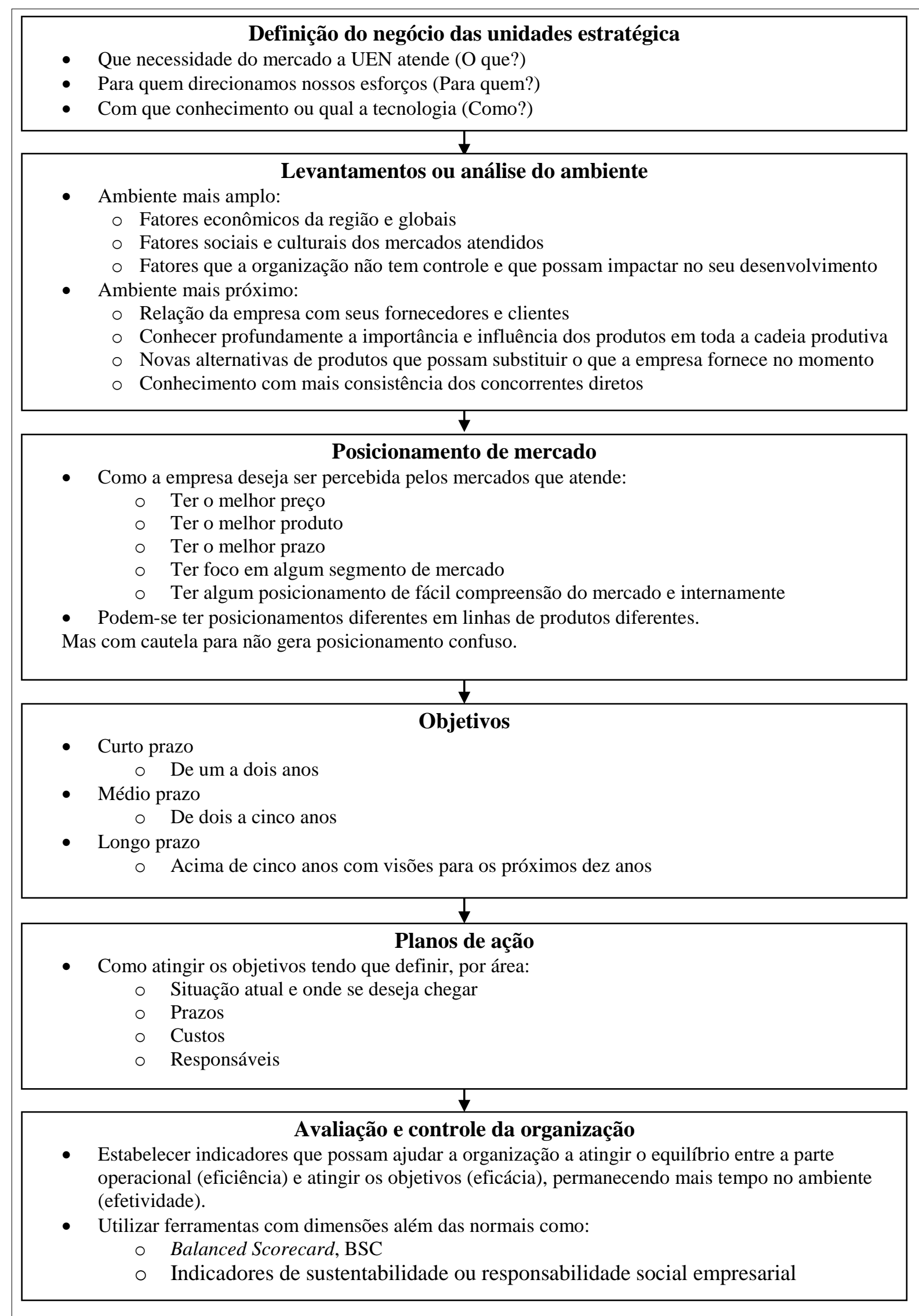

Figura 6 - Sugestão para o desenvolvimento do Planejamento Estratégico para empresas tipo máquina 
Como sugestão do planejamento para empresas profissionais com exceção de faculdades que já possuem um plano de desenvolvimento institucional imposto pelo MEC, tem-se inicialmente em substituição a missão e visão uma projeção da instituição, ou como a instituição deseja ser percebida pelos públicos interessados.

Nas análises do ambiente o foco deve ser em fatores econômicos da região, fatores sociais e culturais que de alguma forma possam impactar favoravelmente ou desfavoravelmente.

Para o ambiente mais próximo da organização, a pesquisa mostrou à forte influência de órgãos governamentais, a comunidade onde a empresa está inserida, os provedores de conhecimento como escolas e faculdades, além de fornecedores monopolistas e concorrentes No posicionamento é importante destacar fatores de diferenciação como serviços, imagem, pessoas ou outro que os públicos interessados percebam.

Os objetivos no caso de instituições de ensino estão atrelados ao ano letivo e no caso de outro tipo de instituição como hospitais podem trabalhar com prazos médios de dois a quatro anos.

Os planos de ação devem ser definidos por área ou setores e os mecanismos de avaliação podem contemplar indicadores como:

diretos.

- Recursos humanos.

- Eficiência operacional.

- Utilização da capacidade.

- Infra- estrutura.

- Responsabilidade social.

- Resultados econômicos- financeiros.

Estrutura sugerida para organização tipo profissional com foco em hospitais de acordo com a Figura 7. 


\section{Projeção da Instituição}

- Como a instituição deseja ser percebida pelos públicos interessados

\begin{tabular}{|c|c|}
\hline \multicolumn{1}{|c|}{ Levantamentos ou Análise do Ambiente } \\
- Ambiente mais amplo: \\
$\circ \quad$ Fatores econômicos da região \\
$\circ \quad$ Fatores sociais e culturais \\
$\circ \quad$ Fatores que a organização não tem controle e que possam impactar no seu \\
$\quad$ desenvolvimento \\
$\circ \quad$ Relação da instituiçãa com seus fornecedores \\
$\circ \quad$ Relação da instituição com o governo \\
$\circ \quad$ Relação da instituição com provedores de conhecimento \\
$\circ \quad$ Relação da instituição com a comunidade \\
$\circ \quad$ Relação com os concorrentes diretos \\
\hline
\end{tabular}

\section{Posicionamento de mercado}

- Como a empresa deseja ser percebida pelo mercado:

- Ter o melhor serviço

- Ter a melhor imagem

- Ter os melhores colaboradores

○ Ter algum posicionamento de fácil compreensão do mercado e internamente

- Curto prazo

\section{Objetivos}

○ Um ano

- Médio prazo

- Até dois anos

- Longo prazo

$\circ$ Acima de quatro anos

Planos de ação por áreas ou setores

- Como atingir os objetivos tendo que definir:

- Prazos

- Custos

○ Responsáveis

\section{Avaliação e controle da organização}

- Desenvolver indicadores para:

- Recursos humanos

- Eficiência operacional

- Utilização da capacidade

- Infra-estrutura

- Responsabilidade Social

○ Resultados econômicos- financeiros

Figura 7 - Sugestão para o desenvolvimento do planejamento estratégico para empresas tipo profissional 
Nas empresas inovadoras a sugestão é também substituir a missão e visão, mesmo que em uma das organizações entrevistadas esta parte não está explicita, por uma definição de negócio que aborde:

- Que necessidade do mercado a UEN atende no momento(O que?)

- Para quem direcionamos nossos esforços (Para quem?)

- Com que conhecimento ou qual a tecnologia (Como?)

$\mathrm{O}$ ambiente mais amplo segue as mesmas indicações, porém com análises mais freqüentes devido ao dinamismo do mercado. Para o ambiente mais próximo a relação da empresa com complementadores passa a ser fundamental, pois estes podem definir elos importantes na cadeia produtiva.

O posicionamento deve estar muito claro para os mercados atendidos e os objetivos, pela flexibilidade de ajuste não devem ultrapassar um ano no longo prazo.

Os indicadores de avaliação e controle de alguma forma serão estabelecidos para acompanhar o dinamismo do mercado, porém os modelos conhecidos podem ser adapatados.

Estrutura sugerida para organização tipo inovadora de acordo com a Figura 8. 


\section{Definição do negócio}

- Que necessidade do mercado a UEN atende no momento(O que?)

- Para quem direcionamos nossos esforços (Para quem?)

- Com que conhecimento ou qual a tecnologia (Como?)

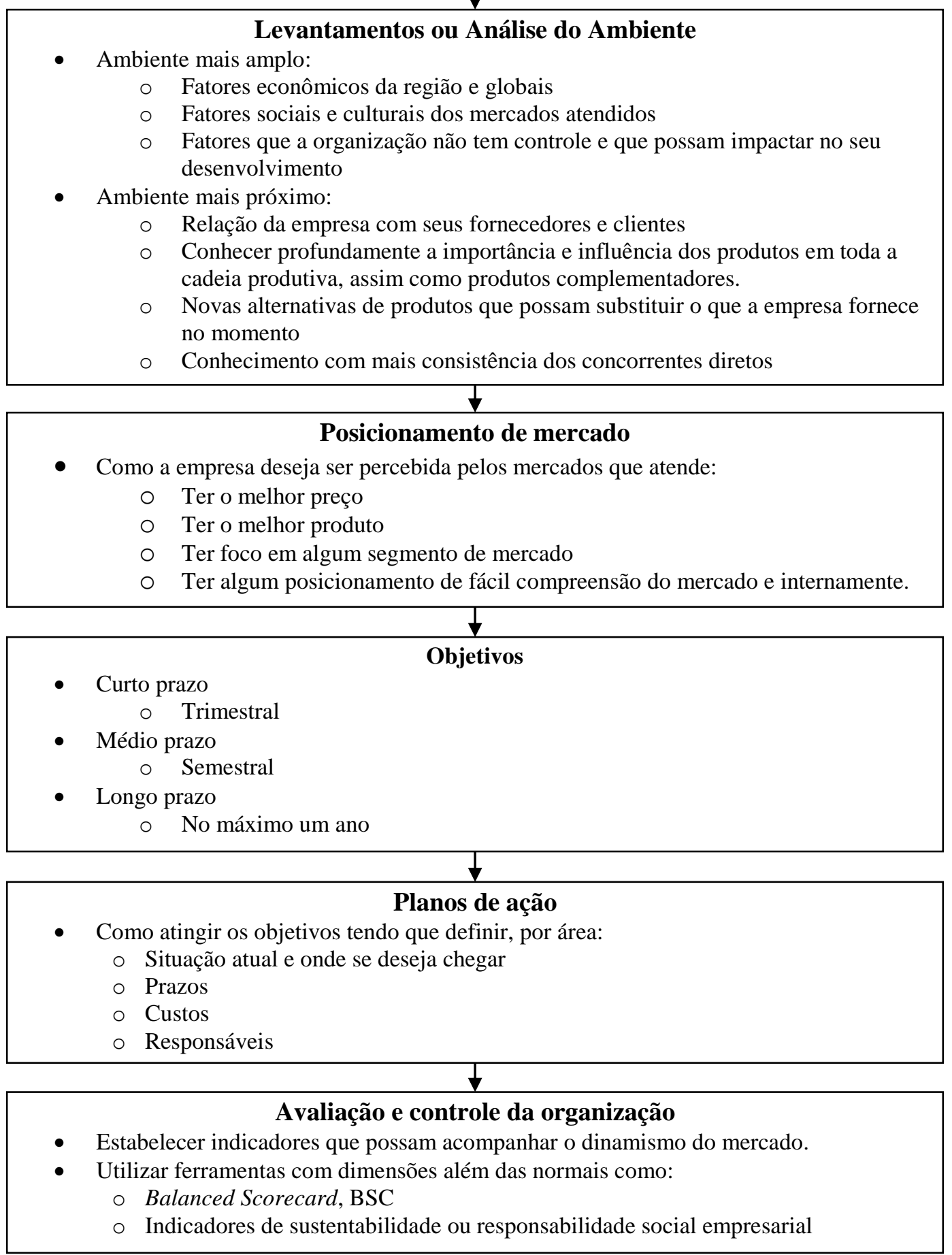

Figura 8 - Sugestão para o desenvolvimento do planejamento estratégico para empresas tipo inovadora 
As proposições adotadas no início do trabalho são de alguma forma corroboradas de acordo com as pesquisas e tem-se um trabalho que pode ajudar o futuro pesquisador ou gestor a melhor lidar com todos os fatores levantados.

De acordo com a análise e resultados apurados vale ressaltar novamente:

- A proposição P1 se confirma deixando claro que organizações tipo empreendedora tendem a visões de curto prazo ou sem o desenvolvimento do planejamento visando mais ações táticas de curto ou médio prazo.

- A proposição P2 não se confirma totalmente, pelas informações levantadas estas organizações apresentam uma característica híbrida, ou seja, existe uma predominância para ênfase nos controles e trabalho repetitivo, porém pelo dinamismo de mercado este tipo de organização está se flexibilizando com áreas de projetos e estruturas que possam migrar da característica funcional.

- Proposição P3 se confirma, pelas pesquisas levantadas percebe-se uma forte dependência das organizações profissionais dos públicos interessados.

- A proposição P4 se confirma apesar das organizações entrevistadas não citarem os termos do referencial teórico como, competências essenciais ou teorias da RBV.

Alguns entrevistados se mostraram interessados pelo trabalho e pretendem utilizá-lo para aprimorar o desenvolvimento do planejamento estratégico, assim como argumentação para melhor negociar com fornecedores, clientes e financiadores.

Antes das entrevistas serem ministradas foi realizado um pré-teste para ajuste do roteiro de forma a não comprometer muito o tempo dos diretores e gerentes. Foi considerado o tempo de em média uma hora por entrevistado como ideal para um período pós-crise.

Como o Universo de pesquisa foi restrito a oito organizações, sendo duas de cada modelo adotado, fica como sugestão avançar com um estudo quantitativo adaptando o roteiro de pesquisa a um questionário com escala Likert para análises mais conclusivas e tratamentos estatísticos. Pode-se também avançar com estudos qualitativos explorando melhor cada modelo escolhido ou trabalhar com novos modelos ou Universos diferentes. 
Deve-se levar em consideração para o futuro pesquisador que não foi fácil o acesso ao Universo pesquisado, uma entrevista pode demorar até três meses para ser marcada e executada e existe uma dependência muito grande do relacionamento do pesquisador com os entrevistados.

A tese em questão não teve apoio financeiro de nenhuma entidade ou bolsa auxílio.

Alguns termos da Administração não são plenamente conhecidos pelas empresas e entrevistados acarretando um esforço do pesquisador em tentar traduzir o roteiro para uma linguagem que possa direcionar as respostas para o objetivo do trabalho.

Para finalizar uma história narrada na Revista Exame, por Lethbridge (2008).

Durante a Segunda Guerra Mundial, o economista americano Kenneth Arrow, que ganharia um Nobel em 1972, foi convocado para liderar um grupo de pesquisadores. A missão era prever as condições meteorológicas nos campos de batalha com um mês de antecedência. Os estatísticos do grupo logo perceberam que as previsões não tinham o menor valor, ou seja, não eram diferentes de um chute qualquer. $\mathrm{O}$ grupo mandou um relatório a seus superiores informando que não enviaria as inúteis previsões. Veio, então, a resposta. "O comandantegeral sabe que as previsões não são boas. No entanto ele precisa delas para fins de planejamento."

Como tomamos decisões baseadas em previsões o tempo inteiro, diante das incertezas que o futuro apresenta, é preciso avaliar os cenários, assumir o risco e decidir. 

AAKER, D. Administração estratégica de mercado. 5ª ed. Porto Alegre: Bookman, 2001.

ACKOFF, R. L. Planejamento empresarial. Rio de Janeiro: LTC, 1974.

ALMEIDA, M. I. R. Manual de planejamento estratégico. 2a ed., São Paulo: Atlas, 2003.

. Planejamento estratégico para unidades e departamentos da USP [tese]. São

Paulo: Universidade de São Paulo, 2004.

.. Por que não desenvolver uma análise ambiental para o planejamento estratégico.

Rio de Janeiro: Enanpad, 1997.

ALMEIDA, M. I. R.; BENNY, Kramer. Estratégia aplicações setoriais. São Paulo: Jurua, 2007.

ANSOFF, Igor. Nova estratégia empresarial. São Paulo: Atlas, 2001.

ARAUJO, Luis César G. de. Tecnologias de gestão organizacional. São Paulo: Atlas, 2001.

BARNEY, J. B, Gaining and sustaining competitive advantage. New Jersey: Prentice Hall, 1997.

Firm resources and sustained competitive advantage. JM, v. 17, n. 1, p. 99-120, 1991.

Strategic factor markets: expectation, luck, and business strategy. Management Science, v. 32, p. 1231-1241, 1986.

BARNEY, J. B.; HESTERLY, W. S. Administração estratégica e vantagem competitiva. São Paulo: Pearson Prentice Hall, 2008.

BETHLEM, A. Estratégia empresarial. São Paulo: Atlas, 1998.

BLAU, P.; SCOTT, R. Organizações formais. São Paulo: Atlas, 1970.

BURNS, T.; STALKER, G. M. The management of innovation.Routledge: Chapman \& Hall, 1961.

CERTO, S.; PETER, J. P.; MARCONDES, R. C.; CESAR, A. M. R. Administração estratégica. $2^{\mathrm{a}}$ ed. São Paulo: Pearson Prentice Hall,2005.

CHANDLER, A. D. Strategy and structure: chapters in the history of industrial enterprise. Cambridge: MIT Press, 1962. 
Scale and Scope. Cambridge: MIT Press, 1990.

CHRISTENSEN, Andrews, HAMERMESH, Richard G., PORTER, M. E. Business policy. Homewood: Irwin-IL, 1982.

CHRISTENSEN, H. K.; MONTGOMERY, C. A. Corporate economic performance: diversification strategy versus market structure.SMJ, v. 8, p. 163, 1981.

CLAUSEWITZ, C. On war. Londres: Routledge e Kegan Paul, 1966.

COLLIS, D. E,; MONTGOMERY, C. Creating corporate advantage. Nova York: Prentice Hall, 1995.

CYERT, R. M.; MARCH, J. A. A behavioral theory of the firm. Nova York: Prentice Hall, 1963.

DIERICKX, I.; COLL, K. Asset stock accumulation and sustainability of competitive advantage. Management Science, v. 35, n. 12, p. 1505-1513, 1989.

DRUCKER, Peter F. The practice of management. New York: Harper Perennial, 1986.

EISENHARDT, K. Building theories from case study research. Academy of Management Review. v. 14, n. 4, 1999.

ETZIONI, A. Análise comparativa de organizações complexas. São Paulo: Zahar, 1974.

Organizações complexas. São Paulo: Atlas, 1976.

FAYOL, Henry. Administração Iindustrial e Geral. São Paulo: Atlas, 1994.

FERREIRA, A. Gestão empresarial. São Paulo: Pioneira, 2000.

FISCHMANN, A. A.; ALMEIDA, M. I. R. Planejamento estratégico na prática. $2^{\mathrm{a}}$ ed. São Paulo: Atlas, 1991.

FLEURY, Maria Tereza Leme; OLIVEIRA JUNIOR, Moacir de Miranda. Gestão estratégica do conhecimento. São Paulo: Atlas, 2001.

FOSS, N. J.The classical theory of production and the capabilities view of the firm, Institute of Industrial Economics and Strategy. Copenhagem: Copenhagen Business School, 1997.

GERSCHENKRON, A. Social attitudes, entrepreneurship and economic development. A Comment. Explorations in Entrepreneurial History, n. 6, p. 245-272, 1953. 
GEUS, A. P. A empresa viva. Rio de Janeiro: Campus, 1998.

GHEMAWAT, P. A estratégia e o cenário de negócios. Porto Alegre: Bookman, 2000.

GIL, A. C. Como elaborar projetos de pesquisa. $4^{\text {a }}$ ed. São Paulo: Atlas, 2007.

GODOY, A. S. Introdução à pesquisa qualitativa e suas possibilidades. Revista de Administração de Empresas, v. 35, n. 2, p. 57-63, 1995 a.

Pesquisa qualitativa em estudos organizacionais. São Paulo: Saraiva, 2006.

Pesquisa qualitativa: tipos fundamentais. Revista de Administração de Empresas, v. 35, n. 3, p. 20-29, 1995 b.

GOOLD, M.; CAMPBELL, A. Strategies and styles: the role of the center in managing diversified corporations. Oxford: Basil Blackwell, 1987.

HAIR JR., J. F.; BABIN, B.; MONEY, A. H.; SAMOUEL, P. Fundamentos de métodos de pesquisa em administração. Porto Alegre: Bookman, 2005.

HALL, R. H. A framework for linking intangible resources and capabilities to sustainable competitive advantage. Strategic Management Journal, v. 14, p. 607-618, 1993.

Organizações: estrutura e processos. $3^{\text {a }}$ ed. Rio de Janeiro: Prentice Hall, 1984.

HAMPTON, D. R.; Management. Nova York: McGraw-Hill, 1986.

HARRISON, J. S. Administração estratégica de recursos e relacionamentos. Porto Alegre: Bookman, 2005.

HARTLEY, Jean F. Case studies in organizational research. In: CASSEL, C.; SYMON, G. Qualitative methods in organizational research: a practical guide. Londres: Sage, 1994.

HCC - HOSPITAL CARLOS CHARGAS. Disponível em <http://www.hcc.com.br>. , Acesso em 29 set 2009.

HEIJDEN, K. V. D. Planejamento de cenários. Porto Alegre: Bookman, 2005.

HEILBRONER, Robert. A história do pensamento econômico. São Paulo: Nova Cultural, 1996.

HITT, M. A.; IRELAND, R. D.; HOSKISSON, R. E. Administração estratégica. São Paulo: Thomson, 2008. 
ITAMI, H. Mobilizing invisible assets. Cambridge: HUP, 1987.

KAPLAN, Robert S.; NORTON, David P. A estratégia em ação - Balanced scorecard.. $13^{\text {a }}$ ed. Rio de Janeiro: Campus, 1997.

KEATS, B. O'NEIL, H. M. Organizational structure: looking through a strategy lens. In HITT, M. A.; FREEMAN, R. E.; HARRISON, J. S. The Blackwell handbook of strategic management. Oxford: Blackwell Publischer, 2001

KLUYVER, C. A.; PEARCE II, J. A. Estratégia uma visão executiva. São Paulo: Prentice Hall, 2007.

KOTLER, P.; KELLER, K. L. Administração de marketing. São Paulo: Prentice Hall, 2006.

LACOMBE, F. J. M.; HEILBORN, G. L. J. Administração: princípios e tendências. São Paulo: Saraiva, 2003.

LEARNED, E. P.; CHRISTENSEN, C. R.; ANDREWS, K. R.; GULTH, W. D. Business policy: text and cases. Homewood: McGraw-Hill, 1965.

LETHBRIDGE, T. Para que servem os analistas. Revista Exame. Ed. 932, ano 42, no 23, 3 $\operatorname{dez} 2008$.

LOASBY, B. J. Long range formal planning in perspective. The Journal of Management Studies, out. p.300-308, 1973.

MAHONEY, J. T.; PADIAN, R. The resource based view within the conversation of strategic management. SMJ, v. 13, n. 5, p. 363-380, 1992.

MARCONI, M. A.; LAKATOS, E. M. Fundamentos de metodologia científica. $5^{\text {a }}$ ed. São Paulo: Atlas, 2003.

MARSHALL, C.; ROSSMAN, G. B. Designing qualitative research. $3^{\text {a }}$ ed. Londres: Sage, 1999.

MAXIMIANO, A. C. A. Teoria geral da administração. São Paulo: Atlas, 2007.

MINTZBERG, Henry. Acessão e queda do planejamento estratégico. Porto Alegre: Bookman, 2004.

O processo da estratégia. $4^{\mathrm{a}}$ ed. Porto Alegre: Bookman, 2006.

Safári de Estratégia. Porto Alegre: Bookman, 2000.

The structure of organizations. Englewood Cliffs: Prentice Hall, 1979. 
MOONEY, J. D. The principles of organization. Nova York: Harper \& Bros, 1947.

MORGAN, G. Imagens da organização. São Paulo: Atlas, 1996.

MUSSON, G. Live histories. Iin: SYMON, G, CASSEL, Walter Richard. Qualitative methods and analysis. Londres: Sage, 1998.

OHMAE, K. Triad power, the coming shape of global competition. Nova York: Free Press, 1985.

ORGANIZAÇÃO PAN-AMERICANA da SAÚDE. Disponível em <http://www.opas.org.br/>. Acesso em 25 jun 2009.

OWENS-ILLINOIS do BRASIL. Disponível em <http://www.o-i.com>. Acesso em 23 out 2009.

PASCALE, R. T. Administrando no limite. São Paulo: Record, 1994.

PENROSE, E. The theory of the growth of the firm. Oxford: Oxford University Press, 1959.

PETERAF, M. A. The cornerstones of competitive advantage: a RBV. SMJ, v. 14, n. 3, p. 179-191, 1993.

PLATT, J. Studies in qualitative methodology a research annual. Londres: JAI Press, 1988.

PORTER, M. E. A nova era da estratégia. Revista HSM Management. Ed. Especial, São Paulo, mar-abr, 2000. 1999.

Competição - Estratégia competitivas essenciais, $2^{\text {a }}$ ed. Rio de Janeiro: Campus,

Competitive advantage: creating and sustaining competitive performance. New York: Free Press, 1985.

Competitive strategy: techniques for analysing industries an competitors. NewYork: Free Press, 1980.

Estratégia competitiva. Rio de Janeiro: Campus, 2005.

Vantagem competitiva. 14 a ed. Rio de Janeiro: Campus, 1989.

PRAHALAD, C. K.; BETTIS, R. A. The dominant logic: a new linkage between diversity and performance. SMJ, p. 485-501, 1986. 
PRAHALAD, C. K.; HAMEL, G. Competindo pelo futuro. São Paulo: Campus 1995.

The core competence of corporation. HBR, v. 68, p. 79-91, 1990.

REBOUÇAS, D. P. de Oliveira. Estratégia empresarial e vantagem competitiva. São Paulo: Atlas, 2001.

Planejamento estratégico. São Paulo: Atlas, 2003.

REED, R.; DEFILLIPPI, R. J. Causal ambiguity barriers to imitation and sustainable. Academy of Management Review, v. 15, p. 88-102, 1990.

RICHARDSON, R. J. Pesquisa social: métodos e técnicas. $3^{\text {a }}$ ed. São Paulo: Atlas, 1999.

RIES, A.; TROUT, J. Marketing warfare. New York: McGraw-Hill, 1986.

RODRIGUES, A. R. R.; NAVARRO, J. R. Changes in the intellectual structure of strategic management research: a bibliometric study of the strategic management journal, 1980-2000. SMJ, v. 25, p. 981-1004, 2004.

ROESCH, S. M. A. Projetos de estágio e de pesquisa em administração. $3^{a}$ ed. São Paulo: Atlas, 2007.

RUMELT, R. P. Towards a strategic theory of the firm. In LAMB, Robert Boyden. Competitive Strategic management. Englewood Cliffs: Prentice Hall, 1984.

SAMPIERI, R.; COLLADO, C.; LUCIO, P. Metodologia de pesquisa. $3^{\text {a }}$ ed. São Paulo: Mc Graw Hill, 2006.

SBT - SISTEMA BRASILEIRO de TELEVISÃO. Disponível em <http://www.sbt.com.br>. Acesso em 27 jul 2009.

SCHEIN, Edgar. Psicología de la organización. Madrid: Del Castillo, 1972.

SCHUMPETER, J. A., Capitalism, Socialism and Democracy, 1942.

SELlTIZ, C.; WRIGHTSMAN, L. S.; COOK, S. W. Métodos de pesquisa nas reações sociais. v. 1. São Paulo: EPU, 1974.

SLOAN, A. P. My years with general motors. Nova York: Currency Books, 1963, 472 p.

SMITH G. A.; CHRISTENSEN, C. R. Suggestion to instructors on policy formulation. Homewood: Irwin, 1951. 
STAKE, R. Case studies. In DEZIN, Norman; LINCOLN, Yvonna (Eds.). Handbook of qualitative research. Londres: Sage, 1994.

TAYLOR, F. W. Princípios de administração científica. São Paulo: Atlas, 1995.

THOMPSON, A.; STRICKLAND III, A. J. Planejamento estratégico, elaboração, implementação e execução. São Paulo: Pioneira, 2000.

TOFFLER, A, Future Shock. Nova York: Bantam Books, 1990.

TZU, S. A arte da guerra. São Paulo: Record, 1996.

VASCONCELLOS, Eduardo; HEMSLEY, Vasconcellos Eduardo. Estrutura das organizações. São Paulo: Thonson Pioneira, 1997.

VICO MAÑAS, A. Estratégia nos negócios: conceitos, alternativas e casos. In. CAVALCANTI, Marly (Org.). Gestão estratégica de negócios - Evolução, cenários, diagnóstico e ação. São Paulo: Thomson, 2007.

VIVO. Disponível em <http://www.vivo.com.br>. Acesso em 10 set 2009.

WEBER, Max. Ensaios de sociologia. Rio de Janeiro: Zahar, 1982.

. Metodologia das ciências sociais. Parte 1. Campinas: Unicamp, 1999.

. Metodologia das ciências sociais. Parte 2. Campinas: Unicamp, 2001.

WERNERFELT, B. A resource base view of the firm. SMJ, v. 5, n, 2, p. 171-180, 1984.

WILLIAMSON, O. E. Markets and hierarchies. Nova York: Free Pass, 1975.

The economic institutions of capitalism: firms, markets, relational contracting. Nova York: Free Pass, 1985.

WRIGTH, P.; KROLL, M.; PARNELL, J. Administração estratégica. São Paulo: Atlas, 2000.

YIN, R K, Estudo de caso, planejamento e métodos. 3 ed. Porto Alegre: Bookman, 2007.

ZAJAC, E.; Yin, X. The strategy/governance structure fit relationship. Strategic Management Journal, v. 25, p. 365-383, 2004. 


\section{Bibliografia Consultada}

ANDREWS, K. R. Corporate strategy as a vital function of the board. Harvard Business Review, v. 59, n. 6, p.174-84, 1981.

BARLEY, Stephen R. Technicians in the workplace: ethnographic evidence for bringing work into organization studies. Administrative Science Quarterly, v. 41, n. 3, p. 404-441, 1996.

BARNARD, C. Organizational and management, select papers, Routledge: USA, 2003.

BARRETO, Aldo de Albuquerque. Perspectivas da ciência da informação. Revista de Biblioteconomia de Brasília, Brasília, v. 21, n. 2, 1997.

Eficiência técnica e econômica e a viabilidade de produtos e serviços da informação. Ciência da Informação, Brasília, v. 25, n. 3, 1996.

BARRY, D. W. Clausewitzian friction and future war, Institute for National Strategy Studies, National Defense University. Washington, DC: McNair Paper, 1996.

BARTON, L. Wellsprings of knowledge building and sustaining the sources of innovation. Boston: HB School Press, 1995.

BATEMAN, Thomas S.; SNELL, Scott A. Administração: construindo vantagem competitiva. São Paulo: Atlas, 1998.

BRANDENBURGER, A.; NALEBUFF, B. Co-opetion, NY Currency Doubleday, 1996.

COLLINS, H. M. The structure of knowledge. Social Research, v. 60, n. 1, p. 95-116, 1993.

COOPER, Robin; KAPLAN, Robert. Activity-based systems: measuring the costs of resource usage. Accounting Horizons, p. 1-13, Sep. 1992.

CRUSIUS, Carlos Augusto. A divisão do trabalho: um modelo de planejamento da educação segundo a abordagem de requisitos de mão-de-obra. Revista Brasileira de Economia, v. 31, n. $1,1977$.

DRUCKER, P. A disciplina da inovação. Harvard Business Review, ago. 2004, p.80-85.

Sociedade pós-capitalista. São Paulo: Pioneira, 1993.

The theory of the business, HBR, set-out, p. 95-104, 1994.

FLEURY, A. C. C.; FLEURY, M. T. Estratégias empresariais e formação de competências. São Paulo: Atlas, 2000. 
GRANT, Robert M. Toward a knowledge-based theory of the firm. Strategic Management Journal, v. 17, p. 109-122, 1996.

KAPLAN, R. S. Measuring manufacturing performance: A new challenge for managerial accounting research. The Accounting Review, Oct, p. 686-705, 1983.

KAPLAN, Robert S.; NORTON, David P. Having trouble with your strategy? Then map It. Harvard Business Review, v. 78, n. 5. p. 167-176, 2000.

The balanced scorecard: measures that drive performance. Harvard Business Review, v. 70,n. 1, p. 71-79, 1992.

KATZ, D.; KAHN, R. Psicologia social das organizações, São Paulo: Atlas, 1970.

KOGUT, Bruce and Udo ZANDER, What firms do? Coordination, identity and learning. Organization Science, v. 7, n. 5, p. 502-518, 1996.

LAWTON, R. L. Creating a customer - Centered culture; leadership in quality, innovation, and speed., s.1., EUA: Quality Press, 1993.

MATTAR, J. A. N. Filosofia e administração, São Paulo: Makron, 1997.

MOORE, Geofrey A. Darwin e o demônio: a inovação em empresas estabelecidas. Harvard Business Review, ago., p. 20-26, 2004.

NELSON, R.; WINTER, S. G. An evolutionary theory of economic change. Cambridge, M.A.: The Belknap Press of,Havard University Press, 1982.

PERROW, C. Complex organization, N Y , 1958.

QUINN, J. B. Intelligent enterprise: a knowledge and service based paradigm for industry, NY, The Free Pass, 1992.

REICH, R. B. The work of nations, NY, Alfred A. Knopf, 1991.

RODRIGUES, J. N. Quanto vale a massa cinzenta da sua empresa? Resenha da obra: EDVINSSON, Leif; MALONE, Michael. Capital intelectual. São Paulo. Disponível em <http://www.janelanaweb.com/livros/edvinsson.html>. Acesso em 13 jun 2008.

ROTH, W. The evolution of management theory. R \& A, 1993.

SELZNICK, P. Leadership in Administration: A Sociological Interpretation. Evanston, IL, 1957. 
SIGMA GUIDELINE. Disponível em <http://www.projectsigma.co.uk/default.asp>. Acesso em 7 jun 2009.

SILVA, R. O. Teorias da administração, São Paulo: Pioneira Thomson, 2001.

STEINER, G. A.; SCHOLLHAMMER, H. Pitfalls in multi-national long-range planning. Long Range Planning, p. 2-12, 1975

THUROW, L. O futuro do capitalismo. Rio de Janeiro: Rocco, 1997.

WEBER, Max. Ciência e política duas vocações. São Paulo: Cultrix, 1999.

Wirtschaft und gesellschaft (economia e sociedade), v. 1 e 2, Brasília: UNB, 1999.

WEBER, R. P. Basic content analysis, NP, Sage, 1990.

WISNER, A. A Inteligência no trabalho: textos selecionados de ergonomia. São Paulo: Fundação Jorge Duprat Figueiredo de Segurança e Medicina do Trabalho. 1994. 